INTERNATIONAL MONETARY FUND

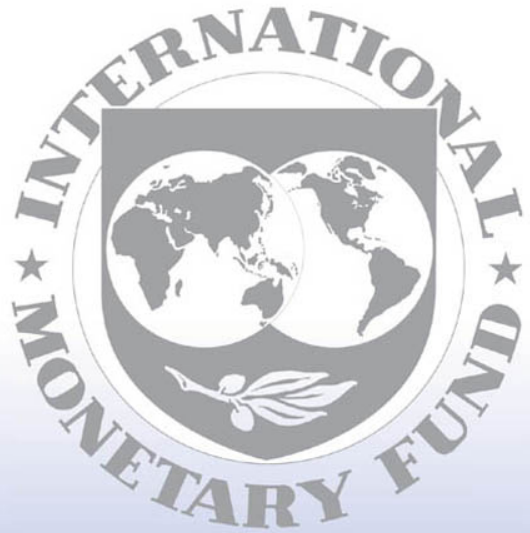

Staff

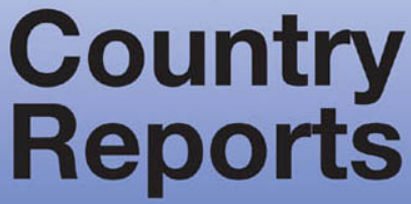




\title{
Bolivia: 2009 Article IV Consultation-Staff Report; Staff Supplement; Staff Statement; Public Information Notice on the Executive Board Discussion; and Statement by the Executive Director for Bolivia
}

Under Article IV of the IMF's Articles of Agreement, the IMF holds bilateral discussions with members, usually every year. In the context of the 2009 Article IV consultation with Bolivia, the following documents have been released and are included in this package:

- The staff report for the 2009 Article IV consultation, prepared by a staff team of the IMF, following discussions that ended on November 18, 2009, with the officials of Bolivia on economic developments and policies. Based on information available at the time of these discussions, the staff report was completed on December 23, 2009. The views expressed in the staff report are those of the staff team and do not necessarily reflect the views of the Executive Board of the IMF.

- A staff supplement on the debt sustainability analysis.

- $\quad$ A staff statement.

- $\quad$ A Public Information Notice (PIN) summarizing the views of the Executive Board as expressed during its January 15, 2010, discussion of the staff report that concluded the Article IV consultation.

- A statement by the Executive Director for Bolivia.

The policy of publication of staff reports and other documents allows for the deletion of marketsensitive information.

Copies of this report are available to the public from

International Monetary Fund $\bullet$ Publication Services

700 19th Street, N.W. • Washington, D.C. 20431

Telephone: (202) 623-7430 - Telefax: (202) 623-7201

E-mail: publications@imf.org • Internet: http://www.imf.org

\author{
International Monetary Fund \\ Washington, D.C.
}




\section{INTERNATIONAL MONETARY FUND}

BOLIVIA

\section{Staff Report for the 2009 Article IV Consultation}

Prepared by the Staff Representatives for the 2009 Article IV Consultation with Bolivia

Approved by Antônio Furtado and Michele Shannon

December 23, 2009

- Discussions. Article IV consultation discussions were held in Santa Cruz and La Paz during November 5-18. Staff representatives comprised by Messrs. Lopetegui (head), Breuer (regional Resident Representative), Peraza, Sosa (all WHD), and Bornhorst (FAD). The team met with finance minister Luis Arce, planning minister Noel Aguirre, central bank president Gabriel Loza, financial sector superintendent Ernesto Rivero, other key public sector officials, and representatives of the private sector.

- Focus of the consultation. Discussions focused on the macroeconomic performance in the context of the global crisis, on the appropriateness of the policy mix for 2010, and on structural issues, in particular initiatives that the authorities are set to launch to implement constitutional mandates.

- Key policy recommendations. As growth is expected to rebound and fiscal policy would provide some impulse, the authorities are advised to curtail the monetary stimulus in 2010. Staff emphasizes the desirability of adopting a framework to manage natural resource wealth to help ensure long-term fiscal sustainability and intergenerational equity, provide for greater policy flexibility in the face of shocks, and facilitate the development of a more independent monetary policy. The mission highlighted the benefits for private sector investment of removing expeditiously uncertainties in the legal framework, especially in hydrocarbon and mining sectors.

- Exchange system. Bolivia has accepted the obligations of Article VIII, Sections 2, 3, and 4. The exchange system is free of restrictions on the making of payments and transfers for current international transactions. The de jure exchange rate regime is a crawling peg, and the exchange rate has been de facto stabilized against the US dollar since October 2008.

- $\quad$ Statistics. Despite shortcomings, data provision is broadly adequate for surveillance. Bolivia has participated in the General Data Dissemination System (GDDS) since November 2002. 


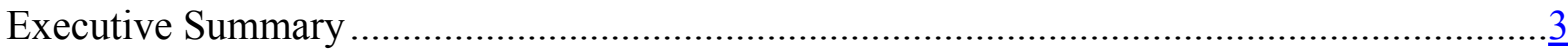

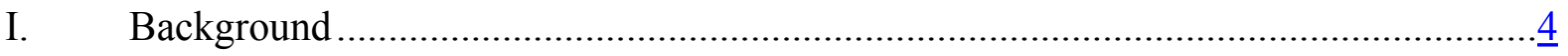

II. Recent Economic developments and Outlook for 2010 ..............................................

III. Policy Discussions ...........................................................................................

A. Macroeconomic Policies ………………….................................................10

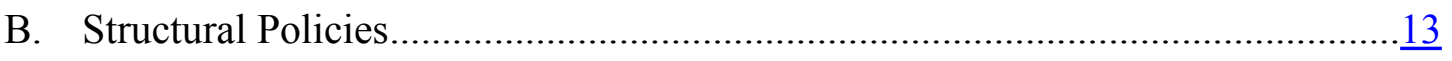

IV. Medium-Term Outlook ....................................................................................

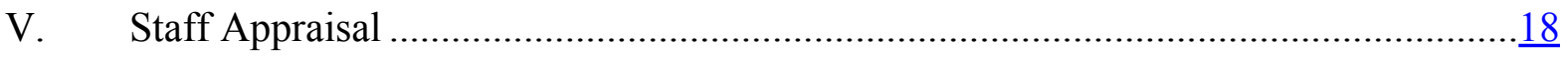

Boxes

1. Fiscal Stance During the Commodity Price Boom....................................................

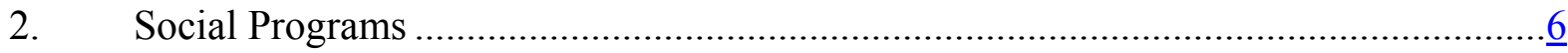

3. Financial Sector Structure and Developments.......................................................

4. Dollarization Trends and Policies .....................................................................

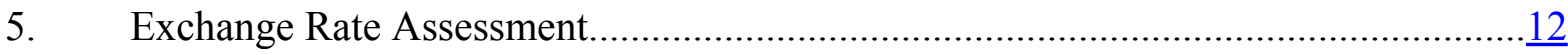

6. Regional Autonomy and Revenue-sharing Arrangements ……................................. 15

7. Upside Risks in Potential Growth........................................................................

Figures

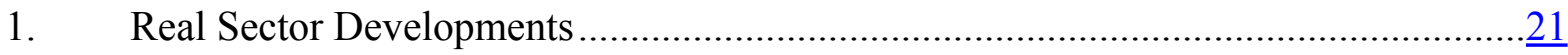

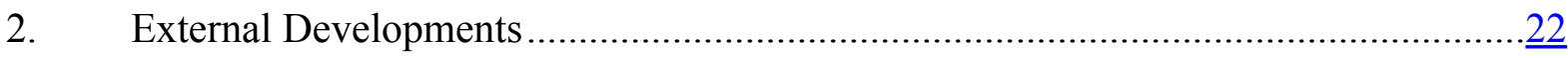

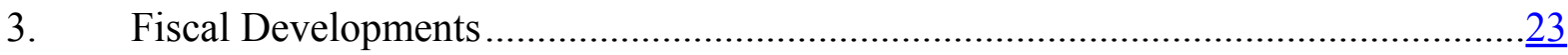

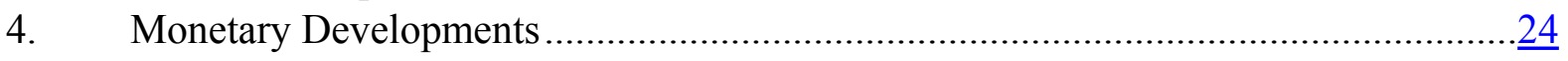

Tables

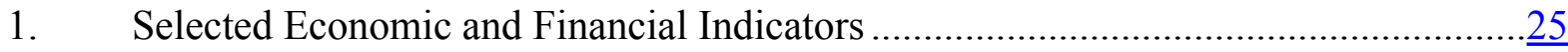

2. Operations of the Combined Public Sector..............................................................

3. Operations of the Combined Public Sector ……….................................................27

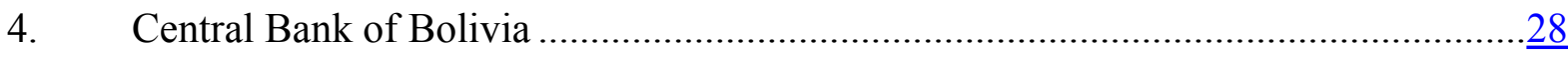

5. Financial System Survey..................................................................................

6. Balance of Payments...............................................................................................

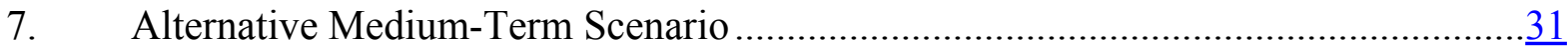

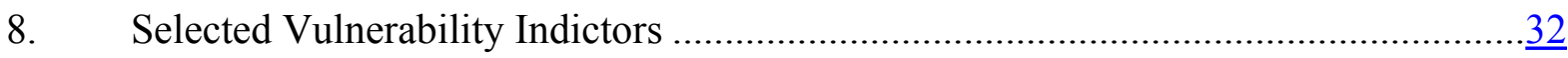

9. Millennium Development Goals ........................................................................

Annexes

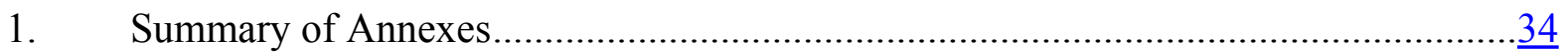




\section{EXECUTIVE SUMMARY}

- In recent years, Bolivia benefited from a sharp improvement in terms of trade. Increased export volumes of gas and mining and the concurrent boom in commodities prices led to a sharp increase in export receipts. Large accumulation of international reserves and significant fiscal surpluses during the boom years contributed to turn Bolivia into a net external creditor.

- The impact of the global recession on Bolivia has been milder than in other countries in the region. In 2009, real output growth is estimated to slow to $3 \frac{1}{4}$ percent, with a sharp decline in inflation. Lower commodity exports and remittances have resulted in a sharp narrowing of the external current account surplus. The financial system has been barely affected by the global crisis owing to its limited integration with international capital markets.

- A moderately countercyclical policy mix has supported domestic demand. In 2009, the fiscal surplus is expected to narrow by 4 percentage points of GDP, to a near balance, largely due to lower hydrocarbon and tax revenue. In parallel, the central bank let short-term interest rates decline to almost zero, which is being transmitted gradually into banks' deposit and loan rates.

- As the economy gathers momentum, a tighter monetary policy is needed to reduce the risks of excessive credit creation, foreign-exchange pressures, and a pickup in inflation. The monetary impulse should be withdrawn-especially if external interest rates were to increase - to absorb excess bank liquidity.

- The fiscal stance for 2010 — including a nearly balanced budget — is consistent with continued domestic and external stability. Staff welcomes the authorities' consideration to a number of reforms that would, over the medium term, reduce excessive reliance on hydrocarbon revenue, including stronger direct taxation, rebalancing of spending responsibilities and revenue assignments across different levels of government, and a fiscal framework for the management of natural resources.

- There is no significant evidence of exchange rate misalignment. The authorities agree that they should resume adjustments under the crawling peg should external imbalances re-emerge. Over the medium term, the authorities should consider moving from the crawling peg towards a more flexible exchange rate regime, to enhance the capacity to respond to external shocks.

- In the financial sector, recent regulations to strengthen liquidity and credit risk management are appropriately focused. Staff suggests pressing ahead with pending structural reforms and maintaining vigilant supervision.

- Improving the investment climate remains a top priority. It will be important that the laws under preparation to implement constitutional mandates are consistent with ensuring a clear and stable framework for private investment. 


\section{BACKGROUND}

1. In recent years, Bolivia benefited from a sharp improvement in terms of trade. Increased export volumes of gas and mining - the result of large investments in hydrocarbon and mining sectors earlier this decade - and the concurrent boom in commodities prices led to a 230 percent increase in export receipts between 2005 and 2008. Real GDP growth, which averaged 3.4 percent annually during 1996-2005, increased to an average of 5.2 percent in 2006-08, peaking at 6.1 percent in 2008 .

\section{The external and fiscal positions strengthened sharply during the boom years.}

Larger export receipts, coupled with higher taxation of the hydrocarbon sector and moderate rates of increase in government spending (Box 1), led to substantial external current account and fiscal surpluses, which averaged 11.8 percent of GDP and 3.8 percent of GDP respectively in 2006-08. These surpluses contributed to the build-up of a comfortable reserves buffer, which - added to the debt relief obtained under MDRI - turned Bolivia into a net external creditor in 2008. Gross public sector debt declined to less than 40 percent of GDP by 2008 and net public sector debt to only 20 percent of GDP, thanks to the accumulation of substantial deposits at the central bank. ${ }^{1}$ However, despite the highly favorable trends, private investment remained subdued, amid political tensions and lingering uncertainty about property rights.

\section{The administration that took office in early 2006 has focused on expanding the} social safety net and improving infrastructure. The government strategy has been to distribute the rents of the natural resource sectors through transfer programs, which are benefiting the poorest segments of the population (Box 2). In addition, investment in infrastructure has gradually increased, to improve access to basic services (water and sanitations, energy) and the transport network (mainly roads).

4. Meanwhile, Bolivia has experienced profound political changes. A centerpiece of this process of change was the adoption of a new constitution in early 2009, which assigns the state a greater role in economic development, including as the main stakeholder in key strategic industries. On December 6, 2009, President Morales - the first president from an indigenous background - was re-elected for a five-year period with continued strong popular support. While social unrest subsided following the approval of the new constitution, the political environment has remained complex in light of continuing regional tensions that complicate fiscal policy coordination between the central and departmental levels of government, and in particular regarding the use of hydrocarbon-derived resources and related expenditure responsibilities.

\footnotetext{
${ }^{1}$ In September 2009, Fitch upgraded Bolivia's Foreign- and Local-Currency Issuer Default Ratings to "B" from "B-“. More recently, Moody's also raised the nation's long-term foreign currency debt rating to B2 from B3.
} 


\section{In completing the 2008 Article IV Consultation, the Executive Board found that} macroeconomic policies were broadly appropriate, and stressed the need for structural reforms as well as improvements in the investment climate. In the fiscal area, Directors recommended improving the efficiency and equity of the tax system, better balancing spending responsibilities and revenue at different levels of government, gradually reducing hydrocarbon subsidies to improve targeting of social policies, and strengthening the budget process. Directors advised introducing prudential regulations to mitigate market risks and credit risks from dollarization, a deposit insurance scheme, and the adoption of legislation governing corporate bankruptcy and restructuring. There has been some progress in the implementation of financial sector reforms and preparations to address fiscal issues are ongoing, including with support of Fund's technical assistance.

\section{Box 1. Fiscal Stance During the Commodity Price Boom ${ }^{1 /}$}

Since 2005 the government has significantly increased its take on the hydrocarbons sector. The special hydrocarbon tax (IDH) effectively increased royalties on hydrocarbon production to 50 percent. At the same time, contracts with foreign companies were re-negotiated, the national oil company (YPFB) was given exclusive rights for the commercialization of hydrocarbon products, and oil companies were re-nationalized. Boosted by high international prices for oil, gas, and mining products, commodity-related fiscal revenues increased from 6.8 percent of GDP in 2005 to 13.4 percent of GDP in 2008 .

Bolivia stands out for using a large part of higher commodity revenues to build macroeconomic buffers during the 2005-08 boom. Compared with other commodity exporters in the region, Bolivia saw the largest increase in commodity revenue and only a moderate increase in public expenditure.

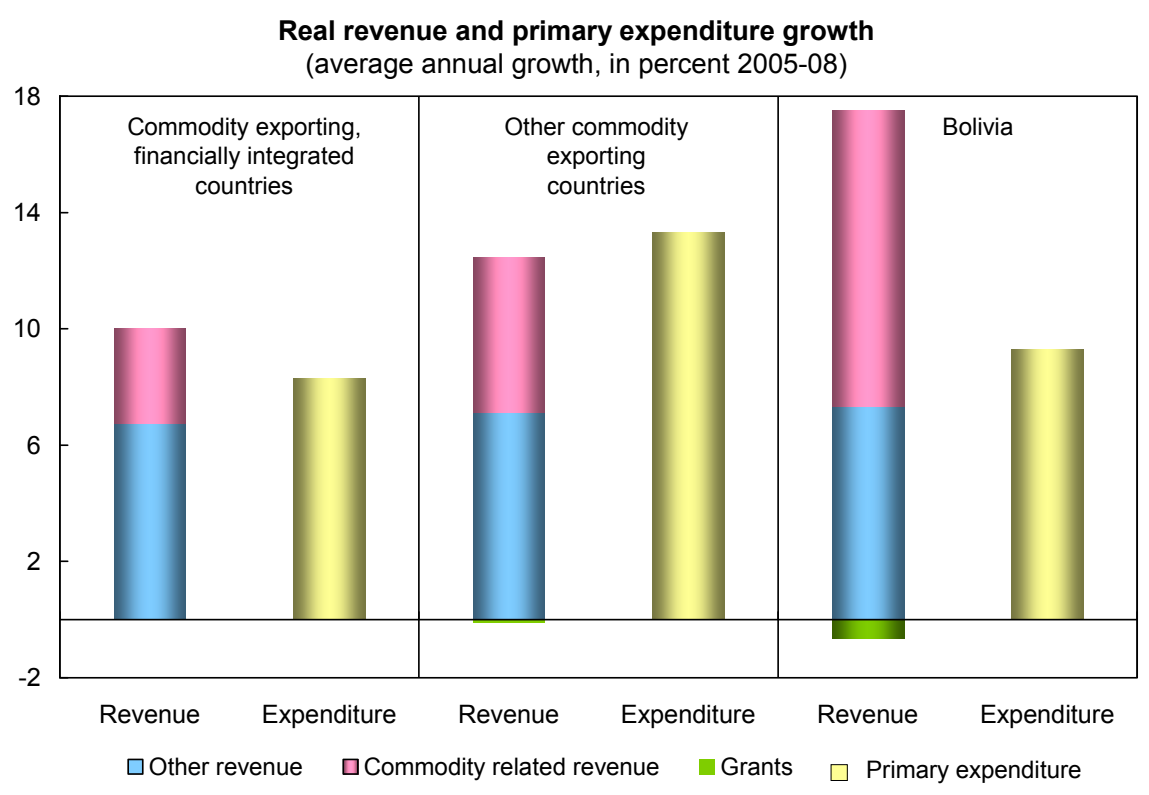

\footnotetext{
${ }^{1 /}$ For details, see Regional Economic Outlook, Western Hemisphere Department, October 2009.
} 


\section{Box 2. Social Programs}

Bolivia remains one of the poorest countries in Latin America. In 2007, 60 percent of the population lived in poverty, and 38 percent in extreme poverty. Extreme poverty is particularly high among the indigenous population (61 percent, compared with 25 percent of the rest of the population). With a Gini coefficient of about 0.6 , Bolivia features one of the most unequal income distributions in the region. Malnutrition, limited access to basic infrastructure (water, sanitation, and electricity) and insufficient health and education facilities inhibit breaking the poverty cycle.

The government has taken significant steps to reduce poverty and improve the social safety net. Various government agencies are implementing a number of social programs. Among them is the extreme poverty eradication program Plan Vida, featuring a phased approach with an initial focus on the poorest geographic areas. Cash transfers are an important component of social policies, including:

- Renta Dignidad is a universal pension introduced in 2008-replacing and augmenting the former Bonosol- for all Bolivians aged 60 and above, equivalent to about US\$340 per year, with reduced benefits for those receiving any other pension. It is financed by a fixed share of the special hydrocarbon tax (IDH), with contributions from all levels of government.

- Bono Juancito Pinto was established in 2007 as a conditional cash transfer program that aims to reduce school drop-out rates by Social spending, percent of GDP, 2007-2009

\begin{tabular}{lrrr}
\hline & 2007 & 2008 & 2009 \\
\cline { 2 - 4 } Anti-poverty spending & 14.2 & 14.0 & 14.0 \\
of which Health & 3.1 & 3.1 & $\ldots$ \\
$\quad$ Education & 5.2 & 5.1 & $\ldots$ \\
Cash transfer programs & 1.1 & 1.7 & 2.0 \\
$\quad$ Renta Dignidad 1/ & 0.8 & 1.4 & 1.5 \\
Bono Juanicito Pinto & 0.3 & 0.3 & 0.3 \\
Bono Juana Azurduy & $\ldots$ & $\ldots$ & 0.2 \\
\hline 1/ For 2007 estimates for Bonosol. & & &
\end{tabular}
offering an annual cash transfer equivalent to about US\$30 for all children attending public primary schools.

- Bono Juana Azurduy is a conditional cash transfer program introduced in 2009 for pregnant women and young children, aiming at improving maternal care, reducing infant mortality, and improving nutritional attainment; the equivalent of about US\$150 is paid for regular pre-natal and pediatric medical checkups.

The authorities reported that social policies are yielding important results, including a reduction in extreme poverty of 4.8 percentage points in 2008 (especially in rural areas), a decline in school dropout rates from 5.2 percent to 2.8 percent following the introduction of the Bono Juancito Pinto, and a reduction in the illiteracy rate.

\section{RECENT ECONOMIC DEVELOPMENTS AND OUTLOOK FOR 2010}

\section{Despite the adverse impact of the global crisis, Bolivia remains in a position of}

low vulnerability. Central bank's foreign reserves have remained at historically high levels, boosted by large valuation gains on non-U.S. dollar assets and the new SDR allocation, ${ }^{2}$ and are equivalent to about 20 months of imports of goods and services and more than 100 percent of deposits in the banking sector, thus providing adequate safeguards in the face of external shocks. ${ }^{3}$

\footnotetext{
${ }^{2}$ The SDR allocation to Bolivia was equivalent to about US\$200 million. The authorities have indicated that they intend to maintain these resources as part of reserves.
}

${ }^{3}$ See Precautionary Reserves: An Application to Bolivia, accompanying Selected Issues Paper (2009). 


\section{While activity slowed down with the global recession, the impact has been} milder than in other countries in the region (Figure 1). Real output growth is projected to slow to $3 \frac{1 / 4}{4}$ percent in 2009 as a result of lower export volumes, mostly due to reduced gas demand from Brazil, and weakened domestic absorption due to the negative terms of trade shock and falling remittances. Lower food prices and a slowdown in domestic demand have contributed to a sharp decline in the 12-month inflation rate, which stood at 0.8 percent in October and is projected at 1 percent by end-2009. Lower commodity exports and remittances have resulted in a sharp narrowing of the external current account surplus to about $3 \frac{1}{2}$ percent of GDP, compared with 12 percent of GDP in 2008 (Figure 2 and Table 4).

8. A moderately countercyclical policy mix has supported domestic demand. The combined fiscal surplus is expected to narrow by 4 percentage points of GDP to an almost balanced position in 2009 , largely due to lower hydrocarbon and tax revenue (by 5 percentage points of GDP) (Figure 3 and Table 2). In parallel, the central bank reduced open market operations while letting the short-term policy interest rates decline to almost zero (Figure 4), in the context of a decline in foreign-currency inflows that had sharply slowed money creation. This is being transmitted gradually into banks' deposit and loan rates, which remain at record low levels ( $1 \frac{1 / 2}{2}$ percent and $8 \frac{1}{2}$ percent respectively). With regard to exchange rate policy, since October 2008 the central bank has effectively pegged the Boliviano to the U.S. dollar, following a period of negative crawl (i.e., gradual appreciation) that started in mid-2005. ${ }^{4}$

\section{The financial system has been barely affected by the global crisis owing to} limited integration with international capital markets. With negligible foreign credit lines in banks' balance sheets and no exposure to impaired foreign assets, banks have remained liquid, profitable, and well capitalized (Box 3 and Table 8). The strengthening of economic fundamentals and measures to induce voluntary Bolivianization of financial assets have led to a significant decline in dollarization (Box 4). Nonetheless, the authorities have increased marginal reserve requirements on dollar deposits to build up a higher foreign-currency liquidity cushion for banks, and also have tightened provisioning requirements, including through higher provisioning for dollar-denominated loans.

\footnotetext{
${ }^{4}$ Bolivia's exchange-rate regime does not contemplate a pre-announced rate of crawl; therefore, the central bank has ample flexibility in terms of the frequency, direction, and magnitude of adjustments.
} 


\section{Box 3. Financial Sector Structure and Developments}

Bolivia's supervised financial system is composed of 63 institutions, with low shares of foreign and public ownership. The system includes commercial banks, microfinance institutions (fondos financieros privados (FFP)), credit cooperatives, credit associations (mutuales), mutual funds, pension funds, and other financial services entities (warehouses, leasing companies, and a second-tier bank). The system is dominated by domestic institutions with only 4 foreign banks altogether concentrating about 15 percent of banking system assets. Only two institutions are owned partially or totally by the state: a commercial bank, Banco Unión, representing about 7 percent of total bank assets, and a second-tier bank, Banco de Desarrollo Productivo (BDP), with assets accounting for about 1.5 percent of total financial system assets.

Financial system assets amount to US\$ 10.4bn (about 60 percent of GDP) with commercial banks controlling over 78 percent of the system's assets (excluding mutual and pension funds). Bolivian banks operate in line with traditional banking activities, but also engage in microfinance operations. In contrast, FFP's are financial intermediaries oriented exclusively to microcredit.

Financial institutions in Bolivia rely almost entirely on deposits. On average, deposits constitute about 90 percent of total liabilities, most of them in demand and savings accounts (52.6 percent of total deposits). FFP's rely more on bank financing, which represents about 20 percent of total liabilities. On the asset side, balance sheets are very liquid, in particular banks, with almost half their assets in liquid instruments including central bank paper. FFP's maintain a larger fraction of their assets in loans due to the dynamism of microfinance. Overall, credit to the private sector has exhibited a moderate nominal expansion in recent years, declining in relation to GDP from 42 percent in 2004 to about 33 percent in 2009.

Key financial soundness indicators are broadly in line with regional averages. Capital adequacy is only slightly lower than the region's average, although a greater difference exists when comparing equity/assets ratios. While delinquency is higher in Bolivia, provisioning levels are also higher and have improved markedly in recent years. Profitability has remained at healthy levels.

The Financial System Supervisory Authority (ASFI) was put in charge of the consolidated supervision of all financial intermediaries (banks and non-banks), as well

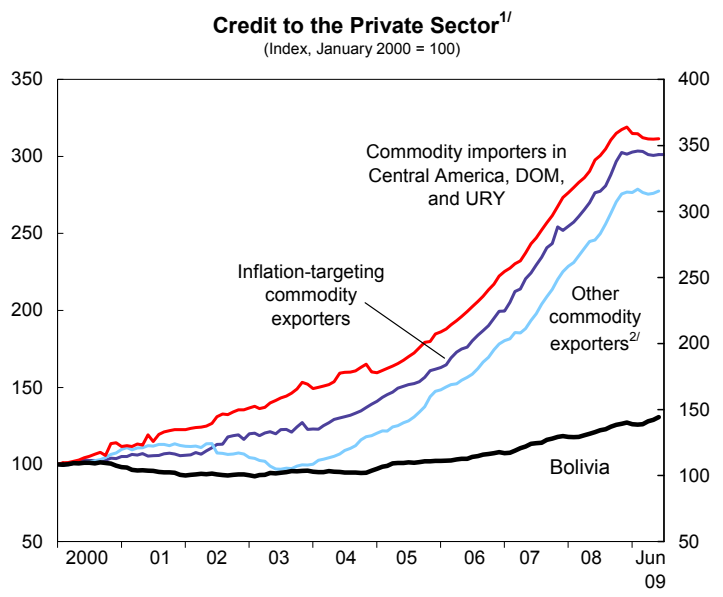

Sources: IMF, International Financial Statistics; and IMF staff calculations

$1 /$ Index constructed using the simple average of monthly growth rates within each group. 2/ Excludes Bolivia, Suriname, and Venezuela.

\begin{tabular}{|c|c|c|c|c|c|c|}
\hline Boli & $\begin{array}{l}\text { Americ } \\
2004\end{array}$ & $\begin{array}{l}\text { Bank } \\
2005\end{array}$ & $\begin{array}{l}\text { ng Sys } \\
2006\end{array}$ & $\begin{array}{c}\text { em In } \\
2007\end{array}$ & 2008 & 20091 \\
\hline \multicolumn{7}{|c|}{ Capital adequacy ratio } \\
\hline Latin America 2/ & 15.9 & 15.6 & 15.1 & 14.5 & 14.6 & 15.3 \\
\hline Bolivia & 14.9 & 14.7 & 13.3 & 12.6 & 13.7 & 13.4 \\
\hline \multicolumn{7}{|l|}{ Equity/assets } \\
\hline Latin America & 10.2 & 10.2 & 10.4 & 10.5 & 10.4 & 10.4 \\
\hline Bolivia & 11.5 & 11.3 & 10.0 & 9.6 & 9.3 & 8.6 \\
\hline \multicolumn{7}{|c|}{ Non-performing loans } \\
\hline Latin America & 5.6 & 4.0 & 3.0 & 2.6 & 2.4 & 3.0 \\
\hline Bolivia & 14.0 & 11.3 & 8.7 & 5.6 & 4.3 & 4.1 \\
\hline \multicolumn{7}{|c|}{ Provisions/Non-performing loans } \\
\hline Latin America & 129.0 & 140.1 & 159.5 & 176.1 & 180.0 & 160.0 \\
\hline Bolivia & 84.2 & 85.9 & 106.5 & 132.4 & 153.7 & 181.0 \\
\hline \multicolumn{7}{|l|}{ Return on assets } \\
\hline Latin America & 1.6 & 2.0 & 2.1 & 2.1 & 1.9 & 1.9 \\
\hline Bolivia & -0.1 & 0.7 & 1.3 & 1.9 & 1.7 & 1.6 \\
\hline \multicolumn{7}{|l|}{ Return on equity } \\
\hline Latin America & 15.3 & 18.9 & 20.9 & 20.9 & 19.8 & 18.6 \\
\hline Bolivia & -1.2 & 6.4 & 13.3 & 21.2 & 20.3 & 19.7 \\
\hline
\end{tabular}
as the insurance and securities market. Since its creation in early 2009, ASFI has continued expanding the supervisory and regulatory perimeter to include cooperatives and other financial institutions. In the area of prudential regulation, ASFI introduced countercyclical provisioning requirements in addition to specific and generic provisioning requirements. 


\section{Box 4. Dollarization Trends and Policies}

Dollarization has declined markedly in recent years in line with improving macroeconomic fundamentals, the authorities' efforts to promote market instruments in Bolivianos, and large net interest-rate differentials. Empirical evidence in the case of Bolivia suggests that improvements in the fiscal balance and the reserve position have a large negative impact on the demand for dollar denominated debt instruments. ${ }^{1 /}$ While there was a slight increase in the share of dollar deposits at the height of the global crisis, the trend is similar to that observed in other highly-dollarized economies, possibly reflecting a temporary rebalancing of private sector portfolios, and lower interest-rate differentials.
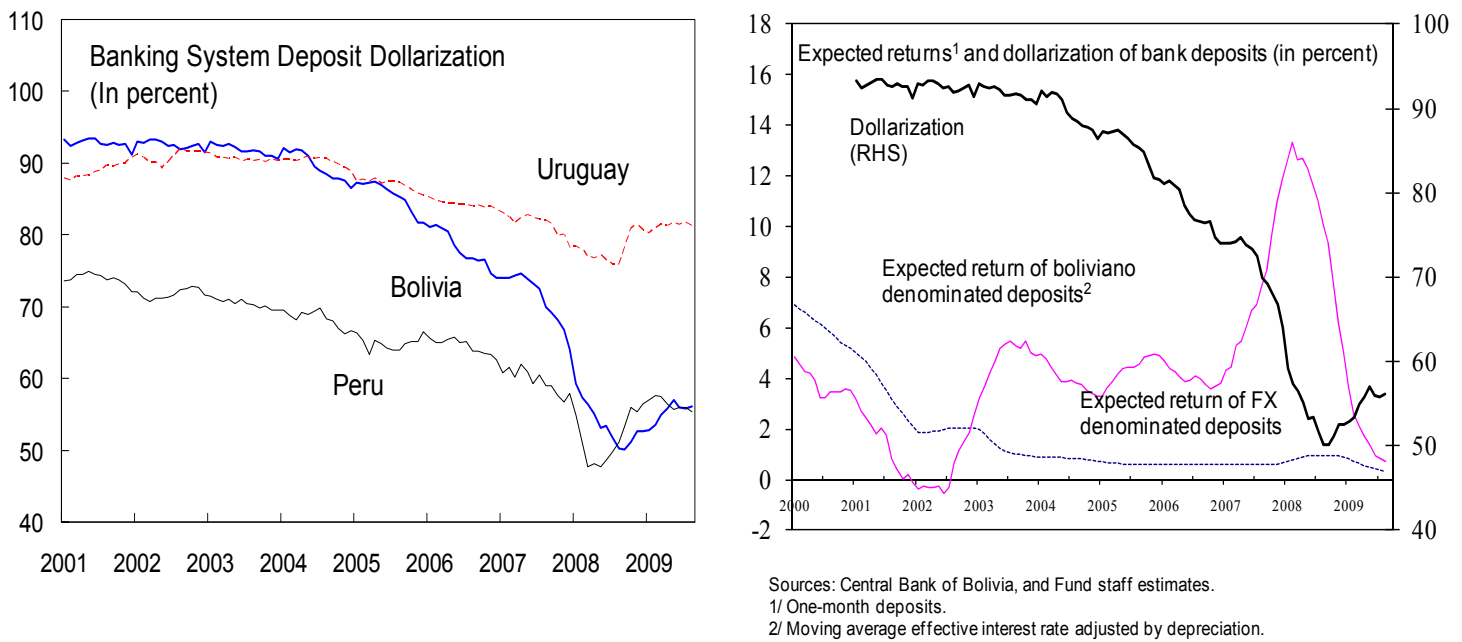

The authorities have adopted a number of measures to make individuals and banks internalize the risks in dollar-denominated financial intermediation. Measures include:

- Marginal cash reserve requirements: financial intermediaries are subject to a marginal cash reserve requirement of 30 percent of deposits in US\$ above the level observed on September 30, 2008.

- $\quad$ Provisioning requirements for dollar-denominated loans: Since early 2009, dollar-denominated loans classified as " $\mathrm{A}$ " (best quality) are required to constitute an additional provision of up to 1.5 percent.

- Financial transaction tax: the tax, at a rate of 0.15 percent for both credits and debits, applies on dollar denominated accounts while transactions in Bolivianos are exempted.

- Bid-ask FX spread: since mid-2005 the central bank began gradually increasing the differential between the buying and selling rate (now at 1.4 percent) to discourage currency shifts.

\footnotetext{
${ }^{1 /}$ Vesperoni and Orellana, Dollarization and Maturity Structure of Public Securities: The Experience of Bolivia, WP/08/157.
} 
10. The macroeconomic outlook for $\mathbf{2 0 1 0}$ is favorable. Real GDP growth is expected to pick up to 4 percent, reflecting mainly a recovery of hydrocarbon exports and public investment, and still favorable terms-of-trade, with inflation projected to rise to about 4 percent. The external current account surplus is expected to narrow moderately to $2 \frac{1}{2}$ percent of GDP, as a result of increased domestic absorption, while the overall balance of payments is projected to remain positive.

Bolivia: Selected Economic Indicators

\begin{tabular}{|c|c|c|c|c|c|}
\hline & 2006 & 2007 & 2008 & $\begin{array}{r}\text { Est. } \\
2009\end{array}$ & $\begin{array}{l}\text { Proj. } \\
2010\end{array}$ \\
\hline Real GDP (percent change) & 4.8 & 4.6 & 6.1 & 3.3 & 4.0 \\
\hline $\mathrm{CPI}$ (end-of-period, percent change) & 4.9 & 11.7 & 11.8 & 1.0 & 4.0 \\
\hline Overall fiscal balance (percent of GDP) & 4.5 & 1.9 & 2.8 & 0.1 & -0.3 \\
\hline of which: Non-hydrocarbons fiscal balance (percent of GDP) & -5.7 & -5.9 & -8.4 & -8.3 & -7.7 \\
\hline Current account balance (percent of GDP) & 11.3 & 12.0 & 12.1 & 3.5 & 2.6 \\
\hline
\end{tabular}

\section{Policy Discussions}

\section{There was agreement that the policy response to the international crisis has}

been appropriate. The central bank argued that the temporary pegging of the exchange rate has been necessary to avoid excessive exchange rate volatility and protect gains from dedollarization, while the comfortable level of international reserves provided ample space to face episodic capital outflows. In parallel, the central bank eased monetary policy beginning in early 2009, thereby supporting domestic demand. On the fiscal front, the authorities allowed automatic stabilizers to operate and protected social and investment expenditure despite the significantly lower revenue. The authorities emphasized that social programs have had an important effect in sustaining domestic consumption, as transfers are oriented towards low income households with high propensity to consume.

\section{A. Macroeconomic Policies}

\section{The overall fiscal position is projected to shift into a small deficit of 0.3 percent} of GDP in 2010. Staff projections suggest that hydrocarbon and tax revenue would remain broadly stable, while the surplus of public enterprises would increase by 1.7 percent of GDP, mostly on account of better results at the state-owned oil company (YPFB), associated with higher gas exports. On the expenditure side, the budget envisages an increase in current and capital expenditure. Budget allocations for wages and pensions would increase by about 10 percent in nominal terms, allowing for a recomposition of real wages after a few years of declines in real terms. Investment, in turn, will pick up at YPFB to advance the industrialization of natural gas, increase production in existing fields, and address other bottlenecks along the production chain. It is expected that this investment 
(US\$ 600 million in 2010, or 3.1 percent of GDP) would be financed by a special credit line from the central bank that was established by law in $2008 .{ }^{5}$

13. The main downside risk to the outlook stems from lower commodity prices and export volumes, should the global economy rebound falter. Staff estimates that a decline in oil prices to just below US\$50 per barrel in 2010 - an event with a 15 percent probability according to current option contracts on oil futures - would have an impact on the external and fiscal balances of 4.8 percent of GDP and 3.8 percent of GDP respectively. While overall reserve cushions would be adequate to prevent the adjustment of fiscal policy in this scenario - if proved temporary - the central administration could face financing difficulties, since the financial cushion of the Treasury is estimated to be relatively small. Upside risks include the possibility of a stronger than expected improvement in commodity prices.

\section{Staff advised tightening monetary conditions as the economy gathers} momentum and the government gradually implements its investment plans. In particular, since government spending is envisaged to expand, the monetary impulse should be withdrawn - especially if external interest rates were to increase - to absorb excess liquidity in the banking system, which stands at about 12 percent of deposits. The mission argued that this would reduce the risks of excessive credit creation, foreign-exchange pressures, and pick-up in inflation. The authorities indicated that they would tighten monetary policy as warranted by inflation and balance of payments developments. For now, they considered that higher credit expansion was needed to support the economic recovery.

\section{The central bank indicated its readiness to resume adjustments under the} crawling peg, in either direction, upon the emergence of external imbalances. However, in the event of pressures toward appreciation, the authorities indicated that they would, at the same time, seek to avoid an excessive erosion of competitiveness vis-à-vis neighboring countries. While there was agreement that there is no immediate need to alter the exchange rate given high and stable international reserves and no significant signs of exchange rate misalignment (Box 5), staff did not see competitiveness issues to be a near-term concern and advised that exchange rate adjustments resume as soon as external conditions implied that significant bank intervention would be needed to maintain the current rate.

\footnotetext{
${ }^{5}$ The 2009 Budget law approved central bank financing to YPFB for up to US\$1 billion (about 6 percent of GDP). Earlier this year, the central bank signed an agreement with YPFB envisaging disbursements up to this total over a 3-year period.
} 


\section{Box 5. Exchange Rate Assessment}

Staff estimates suggest that the Boliviano is broadly in line with fundamentals, with evidence of some undervaluation. These estimates are based on CGER methodologies: the macroeconomic balance (MB) approach, the equilibrium real exchange rate (ERER) approach, and the external sustainability (ES) approach. ${ }^{1}$ While the three approaches point to some undervaluation, all the estimates of undervaluation are smaller than 10 percent, with an average of less than 5 percent. Based on this - and given that the projected current account in the medium term is close to the estimated norm — staff considers the Boliviano to be close to equilibrium.

Bolivia: ER Assessment

\begin{tabular}{lc}
\hline \multicolumn{2}{c}{ REER Deviation from Equilibrium 1/ } \\
(in percent) & \\
\hline MB approach & -1.3 \\
ES approach & -3.1 \\
ERER approach & -8.9 \\
\hline Average & -4.4 \\
\hline
\end{tabular}

Source: Fund staff estimates. 1/ Undervaluation (-), overvaluation (+)

The MB approach points to no real effective exchange rate (REER) misalignment. The REER would need to appreciate by only $1 \frac{1 / 4}{4}$ percent to close the difference between the underlying current account balance $(\mathrm{CAB})$ and the estimated equilibrium $\mathrm{CAB}$, or current account norm. This result hinges on an underlying $\mathrm{CAB}$ equal to $3 \frac{1}{2}$ percent of GDP, and a norm estimated at 2.8 percent of GDP. This level of the current account norm reflects mainly relatively high petroleum trade balances and low old-age dependency ratios.

\section{The ES approach suggests that the} Boliviano is slightly undervalued. Under this approach there is a small undervaluation of about 3 percent, if we assume that Bolivia's net foreign assets stabilize at the end-2008 level.

\section{Finally, the ERER approach points to} some undervaluation. The model

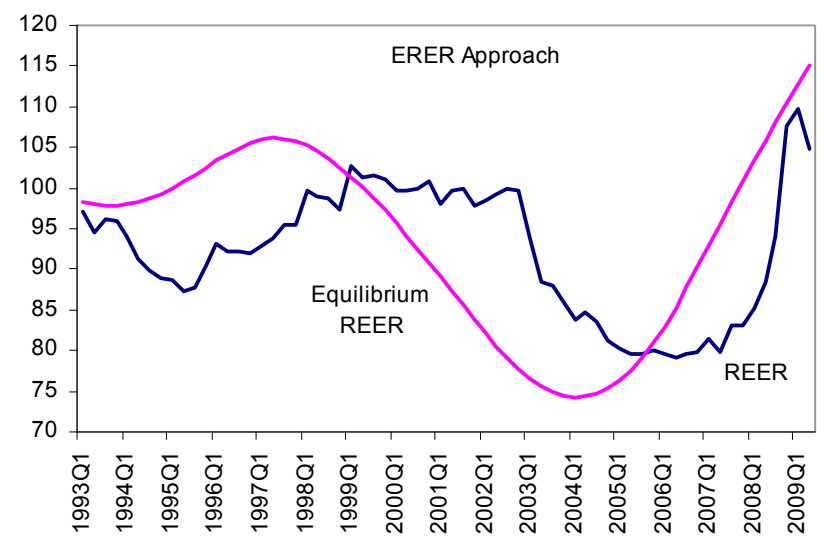
explains the REER on the basis of the terms of trade, net foreign assets, public expenditure, FDI, and relative productivity. The appreciation of the REER in the last quarter of 2008 (mainly a result of trading partners' currency depreciation) almost eliminated the undervaluation observed in 2006-08. However, as the currencies of trading partners recovered in the recent months, the REER depreciated, causing an undervaluation with respect to the estimated equilibrium level of about 9 percent.

There are uncertainties associated with the application of these methodologies to Bolivia. They do not fully incorporate the implications of the exhaustion of a natural resource within a predictable timeframe, and the associated intergenerational considerations that may drive net asset accumulation in the near term. In addition, current account volatility is particularly high in Bolivia because of commodity price fluctuations, which makes it difficult to separate underlying trends from temporary changes, thus complicating the estimation of the underlying current account balance. Finally, the Bolivian economy has experienced large structural changes in recent years; hence, past values of fundamental variables may be poor guides of their appropriate future levels.

${ }^{1}$ For details on these methodologies, see IMF Occasional Paper 261 (2008). 
16. Staff encouraged the authorities to consider replacing the crawling peg, over the medium term, with a more flexible exchange rate regime, to enhance the capacity to respond to external shocks. The authorities concurred that monetary policy should focus primarily on price stability, while allowing the exchange rate to adjust to different external environments. However, they emphasized that a further substantial decline in dollarization would be needed before abandoning the crawling peg regime. Moreover, they emphasized that there is still a strong channel of transmission from the exchange rate to inflation, and that the $\mathrm{crawl}$ gives them some flexibility to adjust to different external scenarios. Staff noted that under the $\mathrm{crawl}$, terms-of-trade volatility would demand skillful liquidity management, and suggested that a fiscal rule to smooth out commodity-price fluctuations would facilitate the move towards more flexibility by reducing the volatility of external imbalances (during oil price booms and busts). To enhance credibility of monetary policy, staff recommended avoiding in the future central bank financing of the government or public corporations.

\section{B. Structural Policies}

\section{The government is embarking on profound legal changes called upon by the} new constitution. The authorities estimate that around 100 laws will need to be approved, including on key structural issues such as intergovernmental relations, the exploitation of natural resources (hydrocarbons, minerals) and land.

\section{Supply Side Policies}

18. The authorities attach importance to strategic partnerships with the private sector to achieve sustained growth. Their development strategy envisages the expansion of natural resource production and its industrialization, which would demand large investments. The authorities' intention is to allow private participation in the capital and management of public enterprises, or to engage in production/service agreements with the private sector, to achieve higher leveraging capacity and facilitate the adoption of modern management techniques and technology. They are working on legal reforms to foster the efficiency of public corporations and provide the tools for effective management, including wage policy and procurement. Staff highlighted that removing expeditiously uncertainties in the legal framework would have benefits for private sector investment, particularly in the hydrocarbon sector. This should be accompanied by a strategy geared specifically to attracting private investment and, more generally, improving the business climate. To help develop the domestic credit market, staff advised introducing modern procedures for the restructuring of private firms, including in the case of bankruptcy, as recommended by the 2003 FSAP to better protect creditors' claims. The authorities noted that they are working on legislation to set up a guarantee fund for medium-size businesses and insurance for agricultural activities, initiatives that would improve access to credit. 


\section{Fiscal Reforms}

19. The authorities are working on a number of initiatives to improve the fiscal policy framework. There was broad agreement on the need to address five important issues:

- Tax reform. This is needed to broaden the non-hydrocarbon tax base to reduce fiscal vulnerability to commodity price shocks and improve the efficiency and equity of the tax system. The authorities are working on a number of measures, with support of technical assistance from the Fund, to make the tax system more progressive. ${ }^{6}$

- $\quad$ Reform of intergovernmental fiscal relations. The constitution draws a road map for the decentralization of government activities, which will start with the approval of the Law of Autonomies in 2010. While reform in this area is likely to be gradual, moving toward a better balance between revenue assignments and spending responsibilities at different levels of government is essential for the central administration to regain strength in its finances, including to finance countercyclical fiscal policy. This will require a pragmatic revision of expenditure responsibilities across levels of government and an appropriate adjustment of the revenue sharing arrangements in the context of the Fiscal Pact (Box 6).

- Long-term framework for the management of natural resource wealth. The authorities are considering adopting a formal framework for the fiscal management of natural resource wealth to enhance macro-fiscal policy effectiveness and serve as a guide to the conduct fiscal policy in the face of volatile external factors. Such a framework will help introduce intergenerational considerations in the exploitation of nonrenewable natural resources and provide for the stabilization of domestic demand through a saving/withdrawal rule to smooth out price fluctuations. Financial savings should be placed in a special government fund with the central bank. Consistent with this approach, the assessment of the fiscal position could be made on the basis of the non-natural-resource balance.

- Public enterprise reform. In addition to the legislation referred to earlier, there is a need for measures to mitigate potential risks to the Treasury from state-owned enterprises. Staff suggested having all state-owned firms subject to annual independent audits and eliminating any fiscal or quasi-fiscal functions by these enterprises. In addition, the Ministry of Economy and Public Finance should develop expertise in the financial operations of the large firms, in particular YPFB. The coverage of public sector accounts should be expanded to include all public enterprises, and their performance reflected in the budget and related documents.

\footnotetext{
${ }^{6}$ See Hydrocarbon Revenue Sharing Arrangements, accompanying Selected Issues Paper (2009).
} 


\section{Box 6. Regional Autonomy and Revenue-sharing Arrangements ${ }^{1 /}$}

\section{The new constitution, ratified in February 2009, calls for the establishment of four subnational} autonomies (departments, regions, municipalities, and indigenous autonomies) and specifies which competencies may or may not be exercised by each level of government. Autonomy statutes, defining the vertical and horizontal distribution of competencies will be drafted, and - subject to passing a local referendum - submitted to the constitutional court for consideration and approval. The Law on Autonomies and related legislation - expected to be passed in 2010 — will govern this process, and implementation is expected to begin in 2011 .

The government has started work to determine the cost of competencies in key areas such as health, education, and infrastructure, based on historic data, to determine the resource transfer that may need to accompany the devolution of competencies in these areas. Resources are intended to be transferred in line with expenditure responsibilities and after assessing the execution capacity of subnational entities. The re-organization of intergovernmental fiscal relations will be managed through a negotiation process known as the Fiscal Pact.

The current revenue-sharing arrangement directs around 55 percent of hydrocarbon revenue $\mathrm{r}^{2 /}$ and 20 percent of other tax revenue to subnational governments and universities. The distribution is not linked to the actual expenditure needs of subnational governments, but is largely determined by their own hydrocarbon production and size. Thus, regional disparities in socioeconomic development remain significant and natural resource endowments continue to be the determinant factor of regional wealth. Through successive changes in Subnational fiscal operations, 2006-2009, percent of GDP revenue sharing, the central

\begin{tabular}{lrrrr}
\hline & 2006 & 2007 & 2008 & $2009(\mathrm{p})$ \\
\cline { 2 - 5 } Overall balance & 4.5 & 2.6 & 4.3 & 0.4 \\
Central administration & 1.9 & 1.6 & -0.3 & -1.6 \\
Prefectures (departments) & 0.8 & 0.6 & 0.2 & $\ldots$ \\
Municipalities & 1.1 & 0.6 & 0.3 & $\ldots$ \\
Hydrocarbon revenue 1/ & & & & \\
Non-financial public sector & 11.6 & 11.3 & 10.6 & 10.5 \\
Central administration & 6.4 & 4.7 & 3.9 & 3.9 \\
Prefectures (departments) & 4.8 & 4.8 & 4.8 & 4.7 \\
Municipalities & 0.3 & 1.5 & 1.5 & 1.5 \\
Universities & 0.1 & 0.4 & 0.4 & 0.4 \\
\hline
\end{tabular}

1/ IDH, royalties and excise tax on fuel. administration's fiscal position has deteriorated steadily, while hydrocarbon revenue windfalls and low spending-execution rates by subnational governments - due to earmarking arrangements and capacity constraints — have led to surpluses and significant deposit accumulation.

\section{A better balance between overall revenue assignments and spending responsibilities would} improve resource allocation. By revisiting the automatic link between hydrocarbon and subnational revenue, pro-cyclical features of subnational spending could be reduced and subnational budget predictability improved. At the same time, such balance would help achieve fiscal neutrality of the decentralization process and rebalance the financial position of the central administration. Earmarking provisions for the use of hydrocarbon revenues could be relaxed to achieve an optimal mix of current and capital expenditure. As regional autonomies begin to exercise their tax authority it will be important to strengthen subnational revenue administration and coordinate tax policies nationally.

\footnotetext{
1/ See Hydrocarbon Revenue Sharing Arrangements, accompanying Selected Issues Paper (2009).

2/ Shared hydrocarbon revenue includes IDH, royalties, and the excise tax on fuel.
} 
- $\quad$ Public sector financial management. As new laws are required to govern the public sector financial administration, the authorities are working on measures to improve the budget process, including with technical assistance from the Fund.

20. Staff encouraged the authorities to revisit the policy on energy subsidies, with a view to creating additional fiscal space for better-focused social programs. Staff noted that in addition to the direct cost to the budget of about 2 percent of GDP in 2010, there are additional costs - from domestic sales at prices below international reference prices - that are putting pressure on the finances of public enterprises, notably YPFB, and represent a significant opportunity cost.

\section{Financial Sector Policies}

21. Staff welcomed recent regulations to strengthen liquidity and credit risk management and suggested to press ahead with pending structural reforms and maintain strong supervision. Staff expressed concern that the new constitution, by eliminating the ability of the central bank to assume any liabilities of failed banks, may limit bank resolution capacity, and encouraged the authorities to establish a deposit insurance scheme, in line with FSAP recommendations. The authorities indicated that financial safety net arrangements were under review and would be addressed when new financial legislation is proposed. There was agreement that a priority in supervision would be to closely supervise credit developments, and that the policy of ASFI - the financial sector regulatory and supervisory body - to expand the perimeter of regulation to non-bank intermediaries was appropriate. The authorities were also encouraged to request an update of the original FSAP assessment conducted in 2003.

\section{The authorities agreed that activities of the Financial Intelligence Unit (UIF)} should be strengthened. While legislation on anti-money laundering appears to be adequate, the definition of terrorist financing activities and its criminalization should be incorporated to the law. Normalization of relations with the EGMONT Group of Financial Intelligence Units and with the Financial Action Task Force of South America (GAFISUD) would be important to avoid negative reputational effects and to benefit from international cooperation, maintain best practices, ensure information exchange, and improve training and sharing of expertise. The adequacy of the size and budget of the UIF should be assessed to ensure that it can conduct its operations effectively.

\section{MEDIUM-TERM OUTLOOK}

23. Over the medium-term, growth is projected to stabilize around 4 percent, inflation to remain in the low single digits, and the external current account surplus to be maintained. Growth would be driven mainly by expansion in the hydrocarbon and mining sectors, as well as by somewhat higher public investment. The current account surplus, in the range of $2-2 \frac{1}{2}$ percent of GDP, would reflect both higher gas exports (due to 
a recovery of international prices and higher export volumes to Brazil) and higher imports (in particular those associated with investment projects in hydrocarbon and mining). Under this scenario, international reserves would continue to strengthen while the gross and net public debt would follow downward trends. ${ }^{7}$ The projected external current account surpluses would contribute to a steady increase in the BCB's net international reserves and the maintenance of safe liquidity cushions. In the fiscal area, after registering a small deficit in 2010 , the overall balance would return to small surpluses, of about $1 / 2$ percent of GDP. Hydrocarbon-related revenue would stabilize at about 10 percent of GDP, and public investment would increase to about $11 \frac{1}{2}$ percent of GDP. The non-hydrocarbon deficit would stabilize at 8 percent of GDP during the projection period.

24. The authorities saw the staff's scenario as subject to upside risks, arising inter alia from the possible implementation of additional investment to further expand gas and mineral production, and to industrialize these natural resources (Box 7$)$. In acknowledging these upside risks, staff emphasized that positive shocks could give rise to mounting appreciation pressures over the medium- and long term, which would have to be addressed by some combination of fiscal and exchange rate adjustment. Staff noted that policy responsiveness in this context would be helped by a move to a more flexible exchange rate regime (as discussed in paragraph 16).

25. Staff suggested that, while the baseline medium-term outlook is consistent with domestic and external stability, intergenerational equity considerations might warrant a reduction of the non-hydrocarbon deficit from projected levels. At current production levels, proven reserves are expected to last about 50 years. ${ }^{8}$ In order to extend the use of hydrocarbon resources beyond this time horizon, the fiscal accounts would need to be strengthened to generate additional savings. For example, staff estimates suggest that saving an additional 1 percent of GDP annually over the next 50 years would extend the hydrocarbon revenue stream by an additional 5 years. Additional savings would provide the basis for building a special fiscal fund, over and above the projected accumulation of central bank international reserves, to allow for the use of hydrocarbon-related resources while maintaining adequate international reserves. While acknowledging the importance of this issue, the authorities suggested that the intergenerational benefits from higher savings out of hydrocarbon resources would have to be balanced against those from development-related expenditure. Moreover, management of hydrocarbon resources needed to be placed in the broader context of the overall natural resource management, including the incipient but highly promising development of Bolivia's massive reserves of lithium — demand for which is likely to rise sharply in coming years as world production of batteries for electric vehicles increases.

\footnotetext{
${ }^{7}$ For a longer term perspective, see the accompanying External and Public Debt Sustainability Analysis.

${ }^{8}$ The authorities expect the results of an ongoing certification of gas reserves by mid-2010.
} 


\section{Box 7. Upside Risks to Potential Growth}

Significant upside risks to potential growth in Bolivia stem from the implementation of various large investment projects envisaged in the National Development Plan but not included in the staff's baseline scenario. Hydrocarbons, mining, and the electricity sector would receive the bulk of these large investments.

- Hydrocarbons. YPFP's plan envisages an increase in production to 100 millions of cubic meters per day $(\mathrm{mm} 3 / \mathrm{d})$ in the medium term, from about $40 \mathrm{~mm} 3 / \mathrm{d}$ in 2008 . To meet this target, both new markets for the additional production and large investments are required. YPFB's investment plan entails investments in exploration and exploitation, transportation and storage, refining capacity, and about 900,000 new household connections in the national gas network. Moreover, the plan envisages key industrialization projects, such as the construction of two separation plants to increase GLP volumes, a project to produce liquids from natural gas, and the construction of a fertilizers plant. Total investments under the plan for 2010-15 would amount to $\$ 11.3$ billion, of which $\$ 7.5$ billion would correspond to the state company.

- Mining. The strategy of the sector envisages substantial investments in exploration, exploitation, and - especially - industrialization. Plans for the production and industrialization of lithium, which represents half of the world's reserves and remains unexploited, are particularly important. A pilot project will start to be implemented next year (aiming at producing 30,000 tons by 2014) in Salar de Uyuni (the world's largest salt flat), where there are approximately 140 million tons of metallic lithium. Several foreign companies have already shown interest in exploiting Bolivia's lithium reserves, and the authorities estimate total potential investments in this area at $\$ 800$ million.

- $\quad$ Electricity. Six large projects - mostly hydroelectric - are in the pipeline for 2010-25, which would more than double the current production capacity of about $1,100 \mathrm{MW}$.

The authorities plan to attract FDI and to develop public-private partnerships to undertake part of these large investment projects. To this end, they intend to promote risk-sharing contracts between the key public enterprises and foreign investors. This is perceived as a key factor to gain capital, technology, know-how, and managerial skills. Key legal reforms are needed to pave the way to attract foreign investment and to implement the ambitious investment plans.

\section{Staff Appraisal}

26. Despite the global crisis, the Bolivian economy has performed well in 2009. Real GDP growth has decelerated due to lower gas exports and a weakening of domestic demand due to falling remittances and lower terms of trade, with inflation declining sharply. The external current account and public sector balances, while strongly impacted by the adverse external shocks, would remain in surplus. NIR have reached record high levels, offering ample coverage of monetary aggregates and, thereby, reducing financial/external vulnerabilities. The financial sector remains sound, with ample levels of liquidity, low nonperforming loans, and adequate provisioning.

\section{The authorities' strategy to deal with the external shock has been appropriate.}

In the face of external risks, the central bank halted the appreciation of the boliviano, providing a stable nominal anchor to avoid exchange rate volatility and protect important 
gains from recent de-dollarization, while using reserves to address temporary capital outflows in late 2008. Interest rates were reduced to stimulate credit demand and support domestic activity. Fiscal policy focused on protecting social and infrastructure spendingalthough the latter suffered from execution delays - while accommodating the cyclical downturn in revenue.

28. As the macroeconomic outlook for $\mathbf{2 0 1 0}$ is favorable, the policy mix should be adjusted. Real GDP growth is expected to pick up reflecting mainly a recovery of hydrocarbon exports and public investment, while inflation is projected to rise moderately. The external current account is expected to remain in surplus while the overall fiscal position is expected to shift into a small deficit. As public expenditure provides further stimulus and the economy rebounds in 2010, the authorities should tighten monetary conditions to prevent excess liquidity in the banking sector, excessive credit creation, foreign-exchange pressures, and a pick-up in inflation.

29. The overall fiscal position remains sound, but the central administration could face financing constraints if oil prices were to fall. Under baseline projections, gross and net public debt are expected to decline gradually over the next few years, consolidating an already strong fiscal position. Because of imbalances between the hydrocarbon-revenue sharing arrangement and spending responsibilities, however, financial savings have been primarily accumulated at subnational level and public enterprises. The financial cushion of the Treasury is estimated to be relatively small, and the central government remains vulnerable to oil price developments. Contingency financing plans should be prepared with a view to protecting investment and social spending.

\section{While the fiscal position is consistent with macroeconomic stability and is} projected to result in lower public debt over the medium term, reliance on revenue from natural resources, particularly hydrocarbons, remains high. Thus, and also on intergenerational equity grounds, the authorities should consider strengthening the nonhydrocarbon balance and generate additional savings to extend the use of hydrocarbon resource wealth beyond its physical depletion. To this end, a number of structural reforms would be helpful and staff welcomes various initiatives under consideration by the authorities. These include, most importantly, stronger direct taxation and the simplification of the tax system; a rebalancing of spending responsibilities and revenue assignments across different levels of government; and a framework for the fiscal management of natural resources. Gradually phasing out fuel subsidies would create fiscal space to increase savings and targeted social spending.

\section{The authorities appropriately stand ready to modify the rate of crawl of the} exchange rate, if needed. Maintaining a stable exchange rate has been useful to address uncertainty in the context of the international economic crisis. While there is no significant evidence of misalignment nor exchange-rate pressures, the authorities should monitor these aspects closely and stand ready to reintroduce a positive or negative rate of crawl, as 
appropriate. Over the medium term, as lower dollarization is more entrenched and domestic financial markets develop further, the authorities should set the stage for greater exchange rate flexibility. An important precondition for a credible and independent monetary policy will be to avoid additional central bank financing of the government or public corporations. Minimizing fiscal dominance, including through fiscal stabilization rules as suggested above, would facilitate the conduct of monetary policy.

\section{In the financial sector, the authorities should focus on pending structural} reforms and maintain a strong financial supervision. As a priority, the authorities should consider creating a deposit insurance scheme and take advantage of the favorable economic environment to finalize the institutional framework to allow the orderly exit of failed institutions. ASFI should continue supervising credit developments closely while expanding the perimeter of regulation and supervision to include cooperatives and other unregulated financial institutions. Legislation on anti-money laundering and the operations of the Financial Intelligence Unit should be strengthened.

33. Improving the investment climate remains a top priority. As the authorities intend to fundamentally reform the legal and institutional framework, it will be important that the laws under preparation to implement the constitution are consistent with ensuring a clear and stable framework for private investment. The authorities should take advantage of these legal reforms to introduce modern procedures for the restructuring of private firms, including in the case of bankruptcy, which would help develop the domestic credit market.

34. It is proposed that the next Article IV consultation with Bolivia be held on the standard 12-month cycle. 
Figure 1. Bolivia: Real Sector Developments

Bolivia's economy has weathered the global recession well. Real GDP growth is expected to decelerate to $31 / 4$ percent in 2009 due to lower gas exports to Brazil, and weakening of domestic demand and falling remittances. Still Bolivia's rate of growth is the highest in the region. Inflation has declined sharply, and is projected at 1 percent by end-2009.

While activity slowed down with the global recession, the impact appears to have been limited...

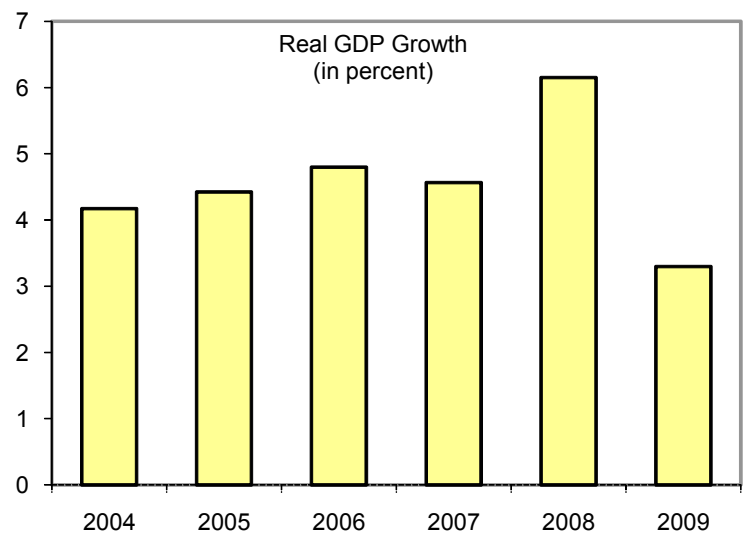

The slowed down reflects lower output in the hydrocarbons sector, mainly due to a decline in demand from Brazil...

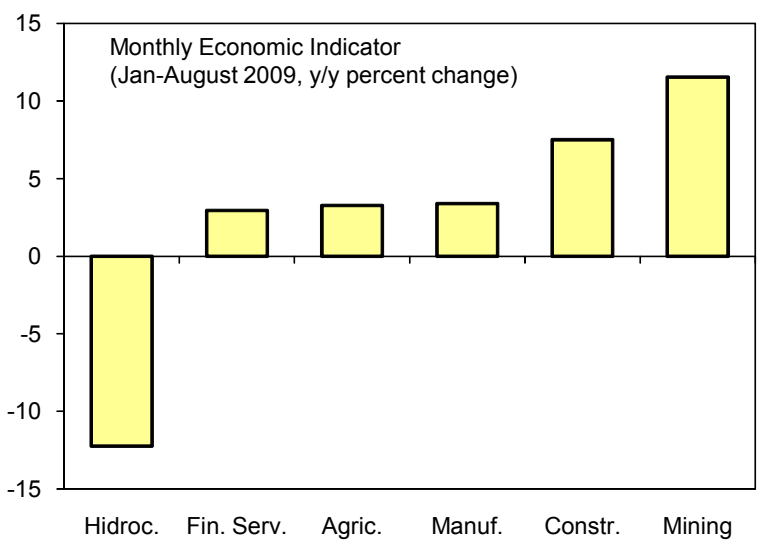

Private investment remains low relative to historical averages and to regional standards.

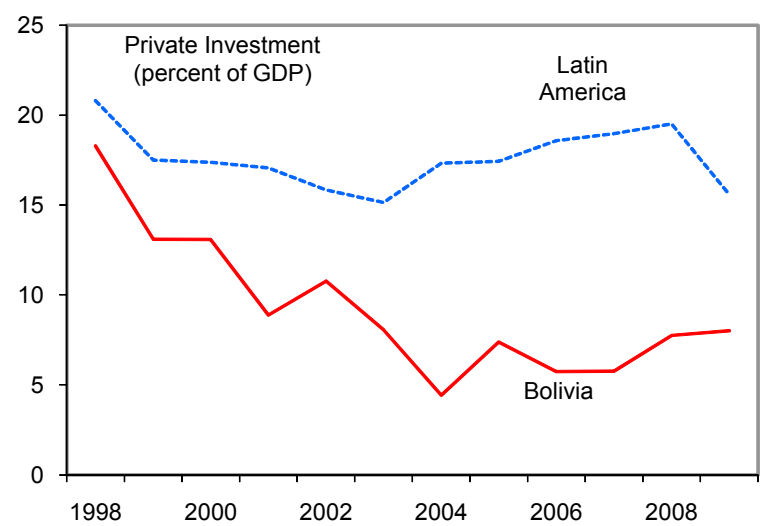

... with real GDP growth expected to decelerate to 31/4 percent in 2009, the highest growth rate in the region.

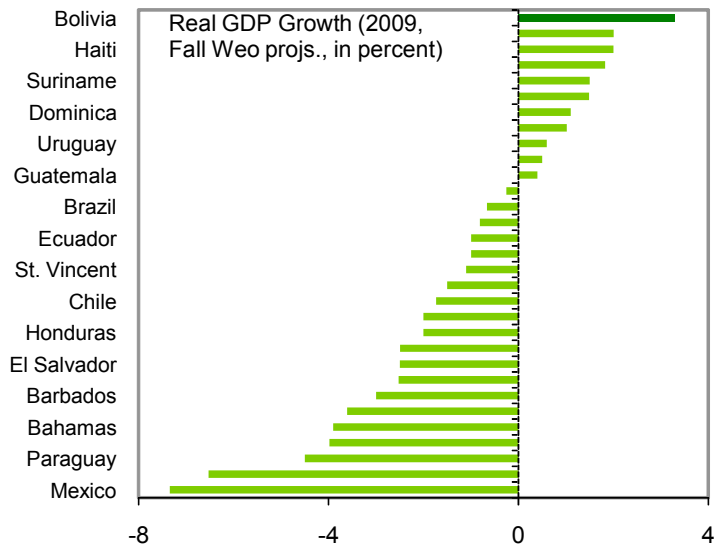

... and weakening of domestic demand.

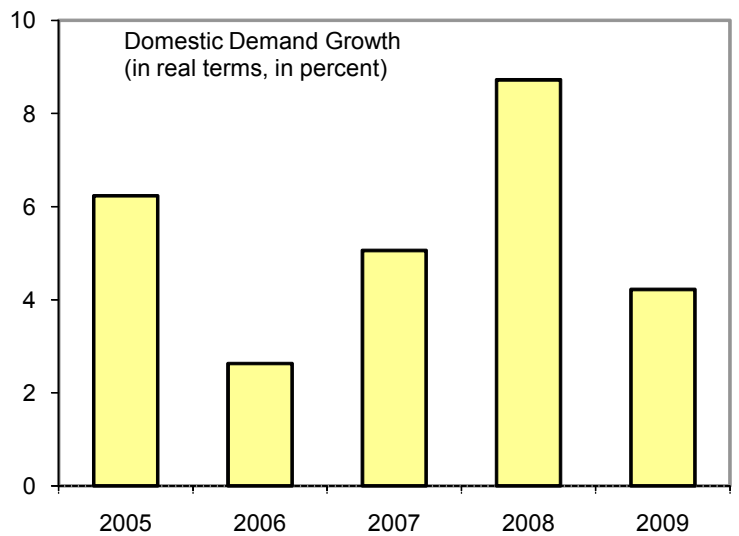

Lower food prices and the slowdown in domestic demand have contributed to a sharp decline in inflation.

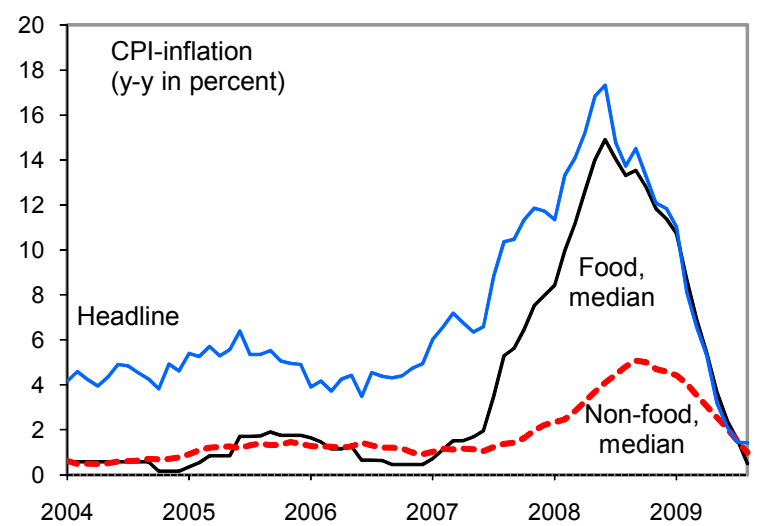

Source: Central Bank of Bolivia and Fund staff estimates. 
Figure 2. Bolivia: External Developments

The external current account surplus will narrow sharply in 2009 mainly on account of lower export prices. Central Bank's foreign reserves remain at historically high levels, with Bolivia turning into a net external creditor in 2008.

Bolivia's current account surplus will decline substantially in $2009 . .$.

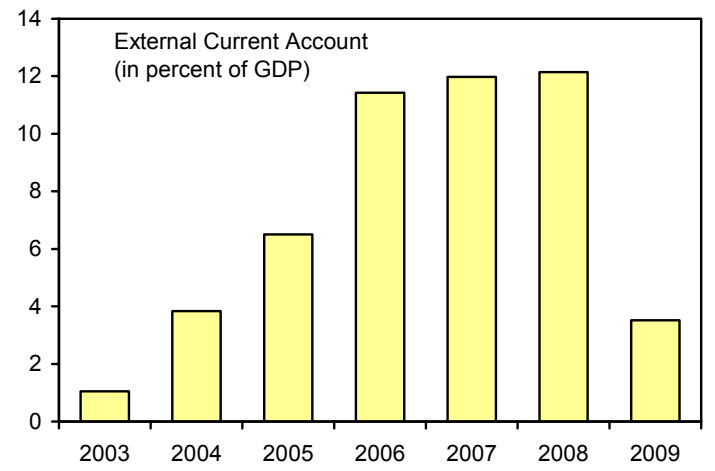

The fall in gas export stems from a decline in both prices and volumes. ...mainly due to lower gas and mining exports, and lower remittances.

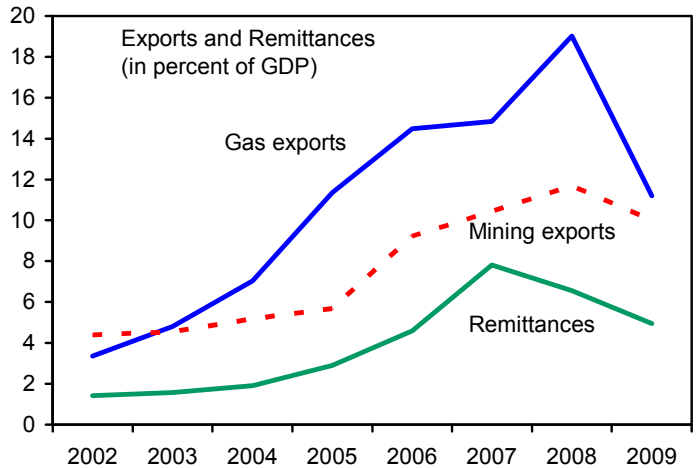

While terms of trade have deteriorated in 2009, they remain at historically high levels.

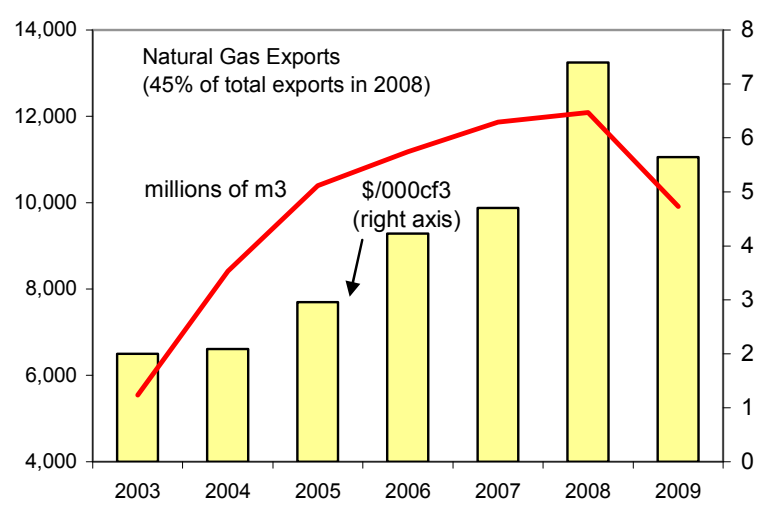

The global turmoil has also affected FDI inflows.

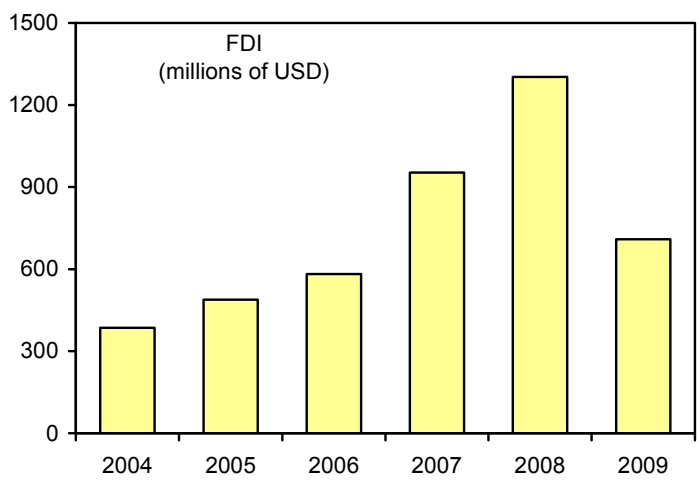

Net international reserves remain high, offering ample coverage of monetary aggregates.

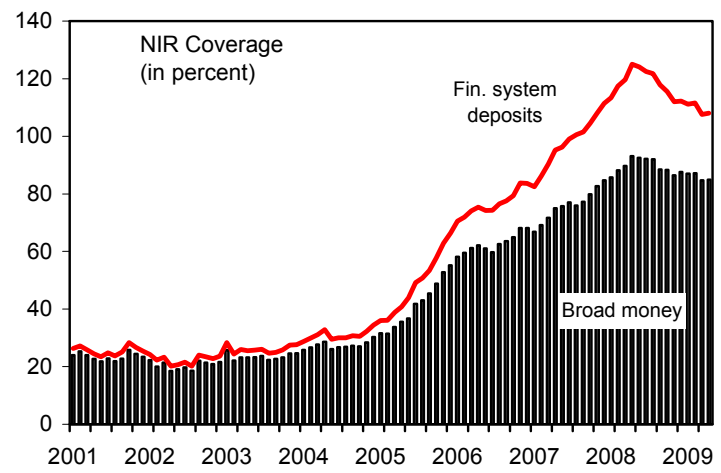

Source: Central Bank of Bolivia and Fund staff estimates. 
Figure 3. Bolivia: Fiscal Developments

Lower commodity prices and export volumes, combined with subdued domestic demand, are projected to shift Bolivia's fiscal position roughly into balance in 2009, after three years of substantial surpluses. Public sector debt has decreased significantly and domestic debt vulnerabilities have been reduced.

The 2009 fiscal balance reversal of 4 percent of GDP mainly reflects a weakening in revenue...

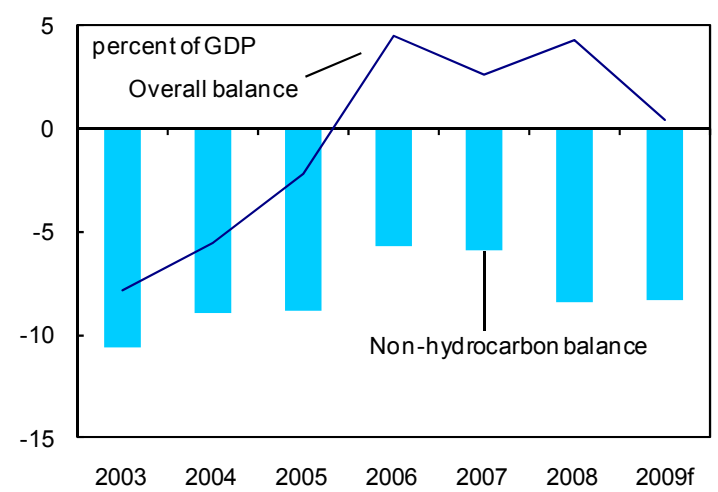

The drop in revenues comes after a period of strong fiscal performance...

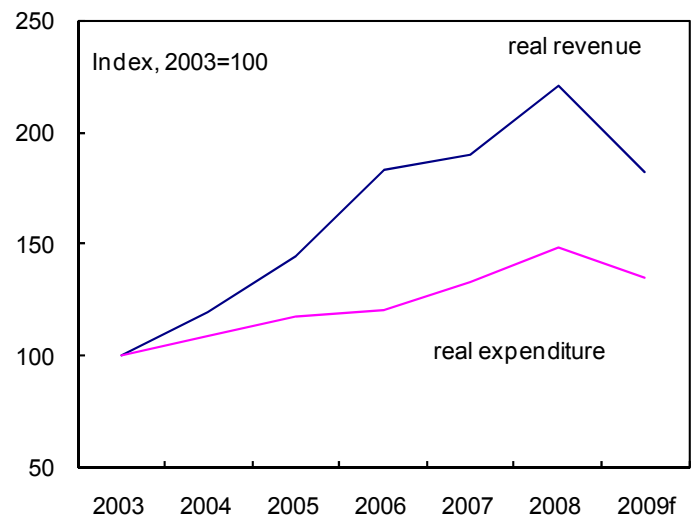

Domestic debt vulnerabilities have been reduced as maturities have been extended...

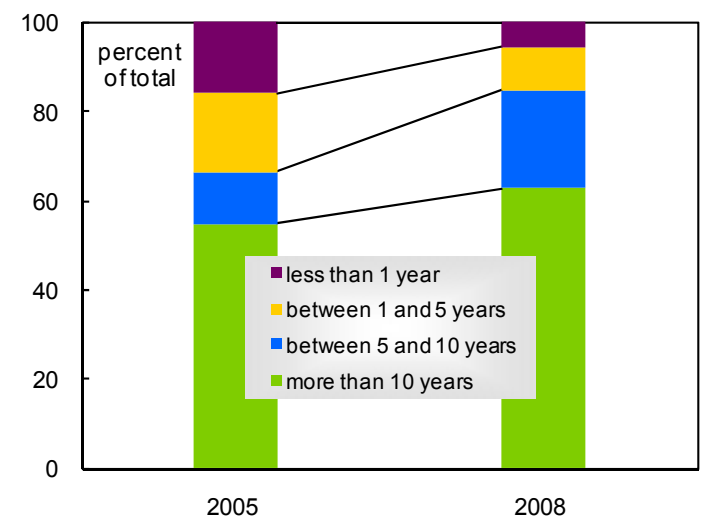

...driven by automatic stabilizers and a decline in hydrocarbon related revenue.

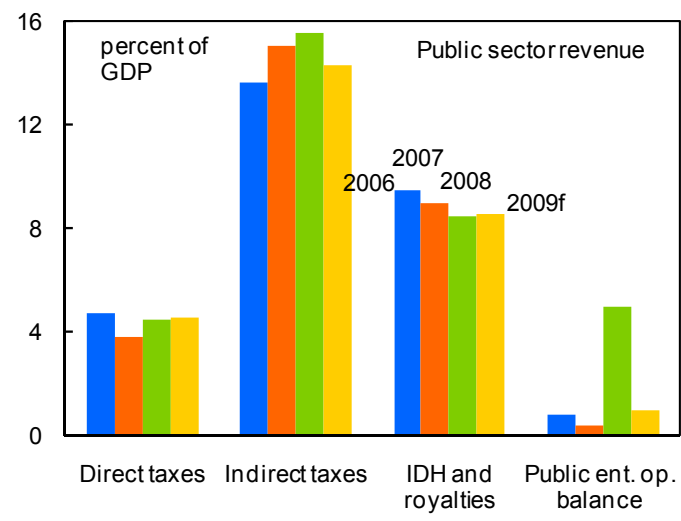

...which, together with debt relief, allowed for a significant reduction in public sector debt.

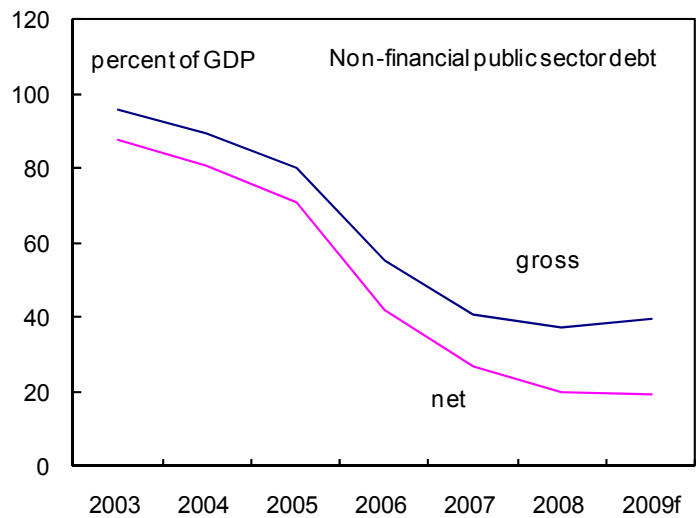

...and foreign currency exposure has been reduced.

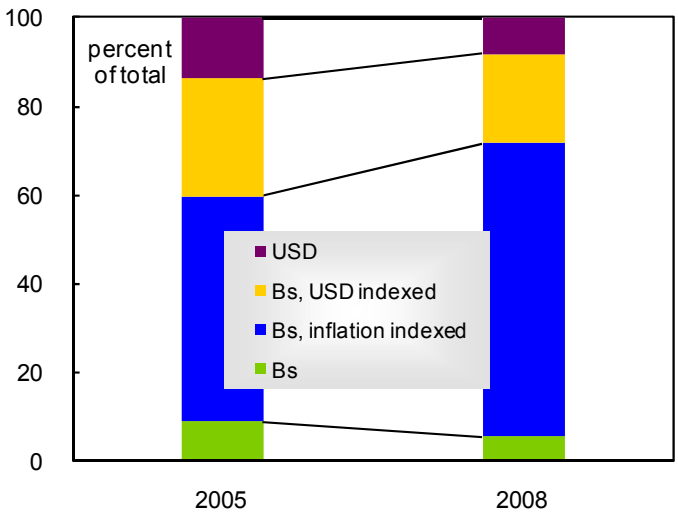

Source: Central Bank of Bolivia, Ministry of the Economy and Public Finances, and Fund staff estimates. 
Figure 4. Monetary Developments

Monetary policy has been eased since July with the central bank reducing the net placements of open market
operations.

The reduction in FX inflows, which had been partially sterilized in boom years,...

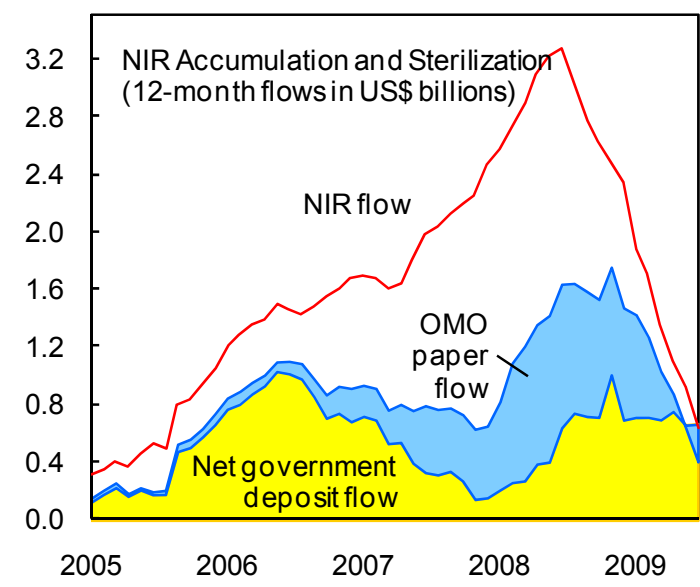

The central bank has maintained a de facto peg for the last 12 months...

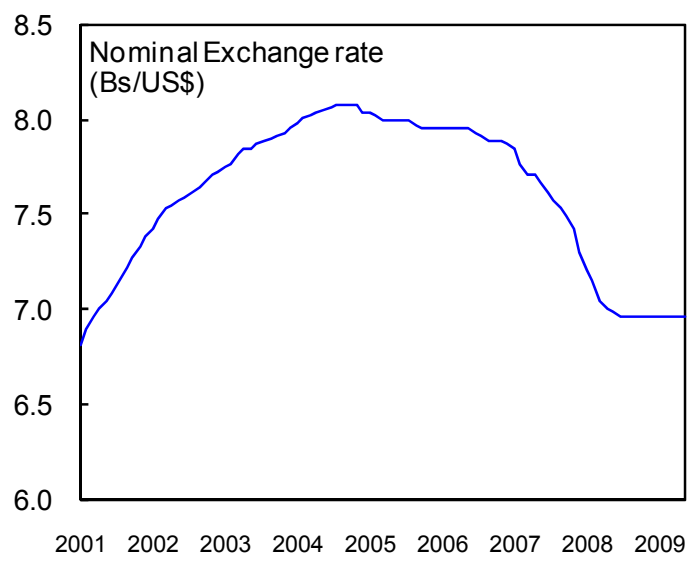

Monetary policy has been eased since July...

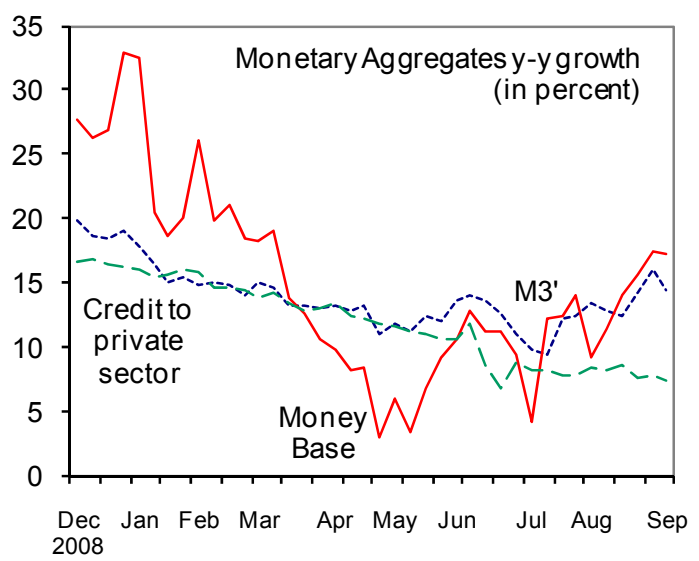

led to a rapid deceleration in monetary aggregates'growth.

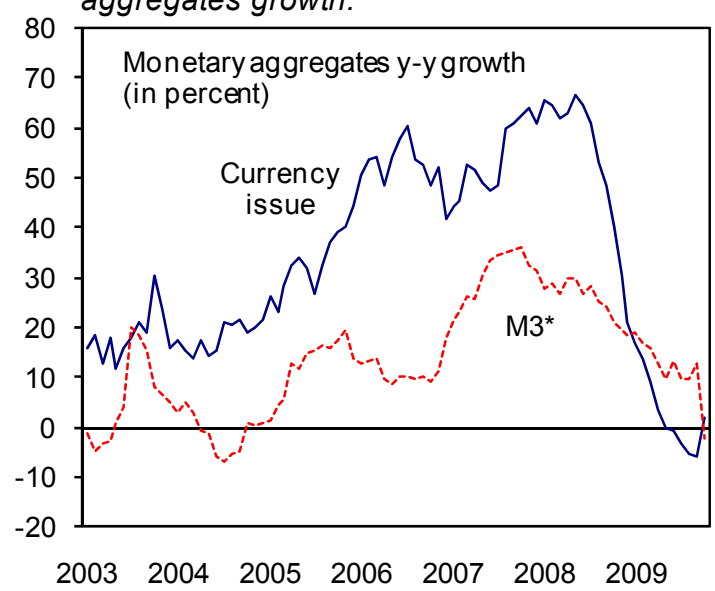

to confront the effects of the global crisis and limit volatility in the FX market.

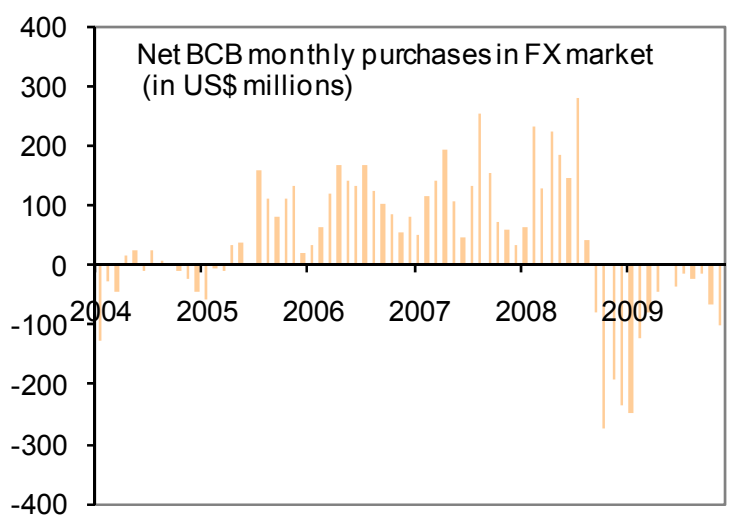

with OMOs rates falling near zero and gradually transmitting to deposits rates.

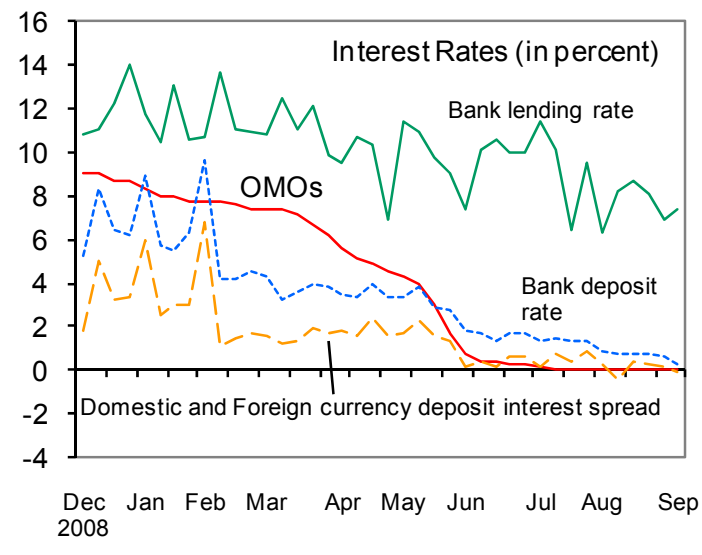

Sources: Central Bank of Bolivia and Fund staff's estimates. 
Table 1. Bolivia: Selected Social and Economic Indicators

I. Social and Demographic Indicators

Area (sq. km)

Arable land (percent of land area, 2003)

Population (2008)

Total (million)
Annual rate of growth, 1991-2002

Population characteristics

Life expectancy at birth in years (2007)

Crude birth rate (per thousand, 2007)

Crude death rate (per thousand, 2007)

Infant mortality (per thousand live births, 2007)

Under 5 mortality rate (per thousand, 2008)

Income distribution (2005)

Gini coefficient

Uistribution of urban labor torce, in percent (2003) Agriculture

Services
Density (per sq. km.)

GDP per capita (US\$) 2008

Industry and mining
$1,084,380$

$$
2.8
$$

9.7

3.5

8.9

$1,714.3$

65.5

27.3

7.6

47.6

0.6

38.3

11.4

50.3
II. Economic Indicators

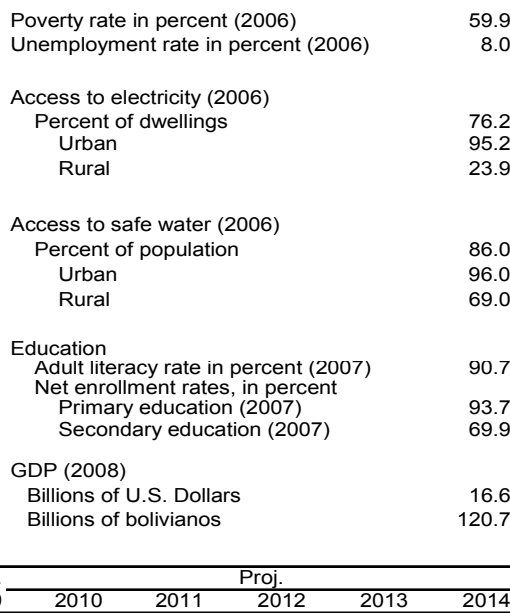

(Annual percentage changes)

Income and prices
Real GDP
GDP deflator
CPI inflation (period average)
CPI inflation (end-of-period)
Investment and savings
Total investment
Public sector
Private sector
Gross national savings
Public sector
Private sector
Investment/saving balances $1 /$
Public sector
Private sector
Combined public sector
Revenues and grants
Of which:
Hydrocarbons related revenue
Expenditure
Current
Capital $2 /$
Overall balance
Of which:
Balance before nationalization costs
Non-hydrocarbons balance, before nationalization cos
Total net public debt
Total gross NFPS debt
External sector
Current account $1 /$
Merchandise exports
Of which: natural gas
Merchandise imports
Terms of trade index (percent change)
Gross Central Bank foreign reserves $3 / 4 /$
In millions of U.S. dollars
In percent of broad money
Exchange rates
Bolivianos/U.S. dollar (end-of-period) $5 /$
REER, period average (percent change)

$\begin{array}{rrrr}4.8 & 4.6 & 6.1 & 3.3 \\ 13.7 & 7.4 & 10.4 & -1.5 \\ 4.3 & 8.7 & 14.0 & 3.5 \\ 4.9 & 11.7 & 11.8 & 1.0 \\ \text { (In percent of GDP) }\end{array}$

$\begin{array}{lllll}4.0 & 4.0 & 4.0 & 4.0 & 4.0 \\ 4.1 & 3.4 & 2.7 & 2.8 & 2.8 \\ 3.3 & 3.7 & 3.5 & 3.5 & 3.5 \\ 4.0 & 3.5 & 3.5 & 3.5 & 3.5\end{array}$

$\begin{array}{rrrrrrrrr}13.9 & 15.2 & 17.6 & 16.1 & 17.1 & 17.4 & 17.7 & 17.7 & 17.8 \\ 8.1 & 9.4 & 9.8 & 8.1 & 8.9 & 9.3 & 9.5 & 9.5 & 9.5 \\ 5.7 & 5.8 & 7.8 & 8.0 & 8.3 & 8.1 & 8.2 & 8.2 & 8.3 \\ 26.4 & 28.6 & 29.0 & 19.6 & 19.7 & 19.4 & 19.7 & 19.8 & 19.9 \\ 12.6 & 11.3 & 12.5 & 8.2 & 8.6 & 9.5 & 9.9 & 9.8 & 9.9 \\ 13.8 & 17.3 & 16.5 & 11.4 & 11.1 & 9.9 & 9.8 & 10.0 & 10.0 \\ 12.5 & 13.4 & 11.5 & 3.5 & 2.6 & 2.0 & 2.0 & 2.2 & 2.2 \\ 4.5 & 1.9 & 2.8 & 0.1 & -0.3 & 0.2 & 0.4 & 0.4 & 0.4 \\ 8.0 & 11.5 & 8.7 & 3.4 & 2.8 & 1.8 & 1.6 & 1.8 & 1.7\end{array}$

$\begin{array}{rrrrrrrrr}34.3 & 34.5 & 38.9 & 32.5 & 34.3 & 34.7 & 35.1 & 34.0 & 34.0 \\ 10.2 & 9.3 & 12.8 & 9.4 & 10.5 & 10.8 & 10.9 & 10.1 & 10.1 \\ 29.8 & 32.8 & 36.5 & 32.6 & 34.7 & 34.7 & 34.8 & 33.8 & 33.7 \\ 19.6 & 20.0 & 23.0 & 22.4 & 24.0 & 23.4 & 23.3 & 22.3 & 22.2 \\ 10.2 & 12.8 & 13.4 & 10.2 & 10.8 & 11.3 & 11.5 & 11.5 & 11.5 \\ 4.5 & 1.7 & 2.8 & 0.1 & -0.3 & 0.2 & 0.4 & 0.4 & 0.4 \\ & & & & & & & & \\ 4.5 & 2.6 & 4.3 & 0.4 & -0.3 & 0.2 & 0.4 & 0.4 & 0.4 \\ -5.7 & -5.9 & -8.4 & -8.3 & -7.7 & -8.7 & -8.7 & -8.0 & -8.1 \\ 41.9 & 26.8 & 20.6 & 19.6 & 18.3 & 16.9 & 15.3 & 14.0 & 12.7 \\ 55.2 & 40.9 & 37.5 & 39.4 & 37.4 & 36.1 & 35.1 & 34.4 & 33.5\end{array}$

$\begin{array}{rrrrrrrrr}11.3 & 12.0 & 12.1 & 3.5 & 2.6 & 2.0 & 2.0 & 2.2 & 2.2 \\ 33.6 & 33.5 & 38.8 & 27.4 & 29.0 & 29.4 & 29.0 & 28.6 & 28.1 \\ 14.5 & 14.8 & 19.0 & 11.2 & 12.9 & 13.5 & 13.2 & 12.9 & 12.6 \\ 24.4 & 26.0 & 30.0 & 24.9 & 27.2 & 27.6 & 27.1 & 26.6 & 26.3 \\ 15.2 & 5.8 & 14.7 & -10.1 & 2.8 & -0.7 & -2.6 & -2.0 & -2.0\end{array}$

$\begin{array}{rrrrrrrrr}3,193 & 5,319 & 7,722 & 8,843 & 9,257 & 9,576 & 9,892 & 10,256 & 10,618 \\ 62.2 & 75.1 & 84.7 & 83.7 & 77.9 & 73.4 & 70.6 & 68.1 & 65.8\end{array}$

$\begin{array}{lllllllll}3,193 & 5,319 & 7,722 & 8,843 & 9,257 & 9,576 & 9,892 & 10,256 & 10,618\end{array}$

...

.9

3.9 6.0 9 .1

.5
.8 9.5
8.3
9.9 9 0.0

\section{(Changes in percent of broad money at the beginning of the period, unless otherwise specified)}

Money and credit

NFA of the financial system

NDA of the financial system

Of which: credit to private sector (percent of GDP)

Broad money

Interest rates (percent, end-of-period)

Yield on treasury bills in local currency

Yield on treasury bills in U.S. dollars

Memorandum items:

Nominal GDP (in billions of U.S. dollars)

Oil prices (in US dollars per barrel) 6/

\begin{tabular}{rrrrrrrrr}
31.3 & 35.4 & 34.6 & 10.2 & 5.8 & 4.9 & 4.2 & 3.7 & 3.0 \\
-12.9 & -3.7 & -12.5 & 6.6 & 6.7 & 4.8 & 3.3 & 3.8 & 4.1 \\
34.7 & 33.1 & 30.3 & 33.0 & 36.1 & 38.5 & 40.1 & 41.7 & 43.4 \\
18.5 & 31.7 & 22.2 & 16.8 & 12.5 & 9.7 & 7.5 & 7.5 & 7.1 \\
& & & & & & & & \\
5.4 & 7.3 & 8.6 & $\ldots$ & $\ldots$ & $\ldots$ & $\ldots$ & $\ldots$ & $\ldots$ \\
4.9 & 4.6 & 4.0 & $\ldots$ & $\ldots$ & $\ldots$ & $\ldots$ & $\ldots$ & $\ldots$ \\
& & & & & & & & \\
11.5 & 13.3 & 16.6 & 17.6 & 19.1 & 20.5 & 21.9 & 23.4 & 25.0 \\
64.3 & 71.1 & 97.0 & 61.5 & 76.5 & 79.5 & 81.0 & 83.0 & 84.8 \\
\hline
\end{tabular}

Sources: Bolivian authorities; World Bank Development Indicators, and Fund staff estimates and projections.

$1 /$ For historical data, the investment-savings balance, as measured in national accounts, differs from that in the balance of payments

due to adjustments in the former associated with estimations of re-exports and smuggling.

2/ Includes nationalization costs and net lending.

2/ Includes nationalization costs and net lending.

3/ Excludes reserves from the Latin Americ

4/ Foreign assets valued at market

6/ Projections based on WEO's August 28 Vintage. 
Table 2. Bolivia: Operations of the Combined Public Sector (In percent of GDP)

\begin{tabular}{|c|c|c|c|c|c|c|c|c|c|}
\hline & \multirow[b]{2}{*}{2006} & \multirow[b]{2}{*}{2007} & \multirow[b]{2}{*}{2008} & \multirow{2}{*}{$\begin{array}{l}\text { Est. } \\
2009\end{array}$} & \multicolumn{5}{|c|}{ Proj. } \\
\hline & & & & & 2010 & 2011 & 2012 & 2013 & 2014 \\
\hline Total revenue and grants & 34.3 & 34.4 & 38.9 & 32.5 & 34.3 & 34.7 & 35.1 & 34.0 & 34.0 \\
\hline Current revenue & 30.9 & 31.1 & 31.5 & 30.4 & 30.1 & 30.4 & 30.2 & 29.9 & 29.7 \\
\hline Tax revenue & 27.8 & 27.8 & 28.5 & 27.4 & 27.0 & 27.4 & 27.3 & 27.0 & 26.7 \\
\hline IDH and royalties & 9.4 & 9.0 & 8.5 & 8.6 & 8.2 & 8.6 & 8.6 & 8.4 & 8.3 \\
\hline Other Taxes & 18.4 & 18.8 & 20.0 & 18.8 & 18.8 & 18.8 & 18.7 & 18.5 & 18.4 \\
\hline Direct taxes & 4.7 & 3.8 & 4.5 & 4.6 & 4.4 & 4.6 & 4.6 & 4.6 & 4.6 \\
\hline Of which: Corporate income tax & 3.1 & 3.0 & 3.7 & 3.9 & 3.7 & 3.9 & 3.9 & 3.9 & 3.9 \\
\hline Indirect taxes & 13.6 & 15.0 & 15.5 & 14.3 & 14.4 & 14.2 & 14.1 & 14.0 & 13.8 \\
\hline Of which: VAT & 6.8 & 7.1 & 7.4 & 6.5 & 6.7 & 6.6 & 6.6 & 6.5 & 6.4 \\
\hline Excise taxes on fuel & 2.2 & 2.3 & 2.1 & 1.9 & 1.8 & 1.8 & 1.7 & 1.7 & 1.6 \\
\hline Nontax revenue & 3.1 & 3.3 & 3.0 & 3.0 & 3.0 & 3.0 & 3.0 & 2.9 & 3.0 \\
\hline Public enterprises operating balance & 0.8 & 0.4 & 4.9 & 1.0 & 2.7 & 2.5 & 2.7 & 1.9 & 2.0 \\
\hline Central bank operating balance & 0.7 & 1.3 & 1.2 & 0.1 & 0.5 & 0.7 & 1.1 & 1.1 & 1.1 \\
\hline Grants & 1.8 & 1.6 & 1.2 & 1.0 & 1.1 & 1.1 & 1.1 & 1.1 & 1.1 \\
\hline Total spending & 29.8 & 31.8 & 34.6 & 32.1 & 34.6 & 34.5 & 34.6 & 33.7 & 33.6 \\
\hline Current expenditure & 19.6 & 20.0 & 22.7 & 22.3 & 23.8 & 23.3 & 23.1 & 22.2 & 22.1 \\
\hline Wages and salaries $1 /$ & 7.9 & 9.2 & 8.7 & 9.7 & 9.8 & 9.6 & 9.6 & 9.6 & 9.6 \\
\hline Goods and services & 1.8 & 2.0 & 2.2 & 2.4 & 2.4 & 2.4 & 2.4 & 2.4 & 2.4 \\
\hline Interest & 2.5 & 2.5 & 2.0 & 2.1 & 2.2 & 2.1 & 2.0 & 1.9 & 1.9 \\
\hline Domestic & 1.5 & 1.7 & 1.4 & 1.6 & 1.5 & 1.4 & 1.3 & 1.2 & 1.2 \\
\hline Foreign & 1.0 & 0.8 & 0.6 & 0.5 & 0.7 & 0.7 & 0.7 & 0.7 & 0.7 \\
\hline Transfers & 1.5 & 2.1 & 6.4 & 4.7 & 5.0 & 4.7 & 4.6 & 3.8 & 3.8 \\
\hline Of which: Fuel subsidies & 1.2 & 0.7 & 3.5 & 1.9 & 2.1 & 1.9 & 1.7 & 1.0 & 1.0 \\
\hline Social programs $2 /$ & $\ldots$ & 0.7 & 2.3 & 2.2 & 2.2 & 2.2 & 2.2 & 2.2 & 2.2 \\
\hline Pensions & 3.6 & 3.4 & 3.1 & 3.5 & 3.7 & 3.7 & 3.7 & 3.6 & 3.5 \\
\hline Other & 2.3 & 0.9 & 0.2 & -0.2 & 0.8 & 0.8 & 0.8 & 0.8 & 0.8 \\
\hline Capital expenditure & 10.2 & 11.8 & 11.9 & 9.8 & 10.8 & 11.3 & 11.5 & 11.5 & 11.5 \\
\hline Of which: YPFB & 0.0 & 0.9 & 0.0 & 0.7 & 3.1 & 1.9 & 1.8 & 1.7 & 1.6 \\
\hline net lending & $\cdots$ & $\cdots$ & 0.8 & 1.4 & $\cdots$ & $\cdots$ & $\cdots$ & $\cdots$ & $\cdots$ \\
\hline Overall balance before nationalization & 4.5 & 2.6 & 4.3 & 0.4 & -0.3 & 0.2 & 0.4 & 0.4 & 0.4 \\
\hline Of which: non-hydrocarbon balance 3/ & -5.7 & -5.9 & -8.4 & -8.3 & -7.7 & -8.7 & -8.7 & -8.0 & -8.1 \\
\hline Nationalization cost & 0.0 & 0.8 & 1.6 & 0.3 & 0.0 & 0.0 & 0.0 & 0.0 & 0.0 \\
\hline Overall balance after nationalization & 4.5 & 1.7 & 2.8 & 0.1 & -0.3 & 0.2 & 0.4 & 0.4 & 0.4 \\
\hline Financing & -4.5 & -1.7 & -2.8 & -0.1 & 0.3 & -0.2 & -0.4 & -0.4 & -0.4 \\
\hline External & 0.4 & 1.0 & 1.3 & 1.3 & 1.0 & 1.3 & 1.4 & 1.5 & 1.4 \\
\hline Disbursements & 2.9 & 3.2 & 3.5 & 3.1 & 3.0 & 2.5 & 2.4 & 2.5 & 2.4 \\
\hline Amortizations & -2.5 & -2.1 & -2.1 & -1.8 & -2.0 & -1.2 & -1.1 & -1.0 & -1.0 \\
\hline Other External & -0.1 & -0.1 & 0.0 & 0.0 & 0.0 & 0.0 & 0.0 & 0.0 & 0.0 \\
\hline Domestic & -4.9 & -2.8 & -4.1 & -1.4 & -0.7 & -1.5 & -1.8 & -1.9 & -1.8 \\
\hline Banking system & -6.2 & -3.2 & -5.4 & -2.4 & -0.7 & -1.5 & -1.8 & -1.9 & -1.8 \\
\hline Of which: Central Bank & -6.2 & -3.0 & -5.0 & -2.6 & -0.7 & -1.5 & -1.8 & -1.9 & -1.8 \\
\hline Commercial banks & 0.1 & -0.2 & -0.4 & 0.2 & 0.0 & 0.0 & 0.0 & 0.0 & 0.0 \\
\hline Pension funds & 1.3 & 0.7 & 0.0 & 1.0 & 0.0 & 0.0 & 0.0 & 0.0 & 0.0 \\
\hline Other domestic & 0.1 & -0.3 & 1.3 & 0.0 & 0.0 & 0.0 & 0.0 & 0.0 & 0.0 \\
\hline Memorandum Items: & & & & 3.8 & & & & & \\
\hline Overall balance of the central administration & 1.9 & 1.6 & -0.3 & -1.6 & $\ldots$ & $\ldots$ & $\ldots$ & $\ldots$ & $\ldots$ \\
\hline Overall balance of subnational governments & 1.9 & 1.1 & 0.5 & $\ldots$ & $\ldots$ & $\ldots$ & $\ldots$ & $\ldots$ & $\ldots$ \\
\hline Prefectures & 0.8 & 0.6 & 0.2 & $\ldots$ & $\ldots$ & $\ldots$ & $\ldots$ & $\ldots$ & $\ldots$ \\
\hline Municipalities & 1.1 & 0.6 & 0.3 & $\ldots$ & $\ldots$ & $\ldots$ & $\ldots$ & $\ldots$ & $\ldots$ \\
\hline Poverty spending & 13.5 & 14.2 & 14.0 & 14.0 & $\ldots$ & $\ldots$ & $\ldots$ & $\ldots$ & $\ldots$ \\
\hline Hydrocarbon related revenue 4 / & 10.2 & 9.3 & 12.8 & 9.4 & 10.5 & 10.8 & 10.9 & 10.1 & 10.1 \\
\hline Hydrocarbon balance & 10.2 & 8.5 & 12.8 & 8.7 & 7.4 & 8.9 & 9.1 & 8.4 & 8.5 \\
\hline
\end{tabular}

Sources: Bolivian authorities and Fund staff estimates.

$1 /$ In 2007 the expenditure on universities was reclassified from other spending into its functional classification, increasing wages and salaries by 1,056 million .Bolivianos in that year. 2/ Excludes part of Bonosol payments in 2007.

3/ Non-hydrocarbon revenue minus overall expenditure plus YPFB capital expenditure.

4/ Hydrocarbon related revenues are defined as IDH, royalties, and the operating balance of YPFB. 
Table 3. Bolivia: Operations of the Combined Public Sector (In Millions of Bolivianos)

\begin{tabular}{|c|c|c|c|c|c|c|c|c|c|}
\hline & & & & & & & Proj. & & \\
\hline & 2006 & 2007 & 2008 & 2009 & 2010 & 2011 & 2012 & 2013 & 2014 \\
\hline Total revenue and grants & 31,473 & 35,428 & 46,953 & 39,944 & 45,629 & 49,667 & 53,617 & 55,563 & 59,318 \\
\hline Current revenue & 28,381 & 32,052 & 38,020 & 37,392 & 40,002 & 43,541 & 46,213 & 48,818 & 51,846 \\
\hline Tax revenue & 25,524 & 28,659 & 34,414 & 33,663 & 35,973 & 39,254 & 41,675 & 44,013 & 46,675 \\
\hline $\mathrm{IDH}$ and royalties & 8,645 & 9,266 & 10,249 & 10,524 & 10,921 & 12,348 & 13,144 & 13,760 & 14,572 \\
\hline Other Taxes & 16,878 & 19,393 & 24,165 & 23,139 & 25,051 & 26,906 & 28,530 & 30,252 & 32,103 \\
\hline Direct taxes & 4,357 & 3,901 & 5,414 & 5,607 & 5,877 & 6,527 & 6,967 & 7,452 & 7,983 \\
\hline Of which: Corporate income tax & 2,884 & 3,141 & 4,468 & 4,775 & 4,963 & 5,549 & 5,930 & 6,336 & 6,773 \\
\hline Indirect taxes & 12,522 & 15,492 & 18,751 & 17,532 & 19,174 & 20,379 & 21,564 & 22,800 & 24,120 \\
\hline Of which: VAT & 6,252 & 7,274 & 8,919 & 7,963 & 8,881 & 9,464 & 10,030 & 10,619 & 11,246 \\
\hline Excise taxes on fuel & 2,000 & 2,383 & 2,530 & 2,364 & 2,459 & 2,558 & 2,661 & 2,767 & 2,878 \\
\hline Nontax revenue & 2,857 & 3,393 & 3,606 & 3,729 & 4,029 & 4,286 & 4,538 & 4,805 & 5,171 \\
\hline Public enterprises operating balance & 732.2 & 384.5 & $5,969.7$ & $1,188.9$ & $3,538.0$ & $3,619.3$ & $4,074.0$ & $3,080.6$ & $3,555.0$ \\
\hline Central bank operating balance & 668 & 1,297 & 1,457 & 126 & 626 & 933 & 1,649 & 1,867 & 1,996 \\
\hline Grants & 1,692 & 1,695 & 1,505 & 1,237 & 1,463 & 1,573 & 1,681 & 1,796 & 1,920 \\
\hline Total spending & 27,372 & 32,767 & 41,754 & 39,406 & 46,008 & 49,381 & 52,948 & 54,981 & 58,602 \\
\hline Current expenditure & 18,000 & 20,594 & 27,402 & 27,345 & 31,697 & 33,280 & 35,359 & 36,188 & 38,513 \\
\hline Wages and salaries $1 /$ & 7,230 & 9,431 & 10,521 & 11,944 & 13,027 & 13,700 & 14,678 & 15,715 & 16,836 \\
\hline Goods and services & 1,649 & 2,031 & 2,680 & 2,972 & 3,218 & 3,459 & 3,697 & 3,950 & 4,222 \\
\hline Interest & 2,318 & 2,616 & 2,386 & 2,544 & 2,930 & 2,986 & 3,059 & 3,155 & 3,257 \\
\hline Domestic & 1,358 & 1,749 & 1,681 & 1,936 & 2,010 & 2,010 & 2,010 & 2,010 & 2,010 \\
\hline Foreign & 960 & 867 & 706 & 608 & 920 & 976 & 1,050 & 1,145 & 1,247 \\
\hline Transfers & 1,396 & 2,132 & 7,717 & 5,810 & 6,610 & 6,786 & 7,010 & 6,258 & 6,641 \\
\hline Of which: Fuel subsidies & 1,065 & 688 & 4,264 & 2,309 & 2,819 & 2,711 & 2,654 & 1,604 & 1,666 \\
\hline Social programs $2 /$ & $\ldots$ & 671 & 2,732 & 2,667 & 2,888 & 3,105 & 3,318 & 3,546 & 3,790 \\
\hline Pensions & 3,284 & 3,487 & 3,800 & 4,359 & 4,899 & 5,259 & 5,635 & 5,879 & 6,110 \\
\hline Other & 2,123 & 897 & 297 & -284 & 1,013 & 1,089 & 1,280 & 1,231 & 1,447 \\
\hline Capital expenditure & 9,372 & 12,173 & 14,352 & 12,061 & 14,311 & 16,101 & 17,589 & 18,793 & 20,089 \\
\hline Of which: YPFB & 31 & 890 & 53 & 836 & 4,182 & 2,788 & 2,788 & 2,788 & 2,788 \\
\hline net lending & $\cdots$ & $\cdots$ & 981 & 1,694 & $\cdots$ & $\ldots$ & $\ldots$ & $\ldots$ & $\ldots$ \\
\hline Overall balance before nationalization & 4,101 & 2,661 & 5,199 & 538 & -379 & 285 & 669 & 581 & 716 \\
\hline Of which: non-hydrocarbon balance $3 /$ & $-5,246$ & $-6,050$ & $-10,191$ & $-10,183$ & $-10,196$ & $-12,424$ & $-13,231$ & $-13,071$ & $-14,161$ \\
\hline Nationalization cost & 0 & 868 & 1,872 & 420 & 0 & 0 & 0 & 0 & 0 \\
\hline Overall balance after nationalization & 4,101 & 1,793 & 3,327 & 118 & -379 & 285 & 669 & 581 & 716 \\
\hline Financing & $-4,101$ & $-1,793$ & $-3,327$ & -118 & 379 & -285 & -669 & -581 & -716 \\
\hline External & 370 & 1,063 & 1,612 & 1,581 & 1,364 & 1,879 & 2,072 & 2,473 & 2,422 \\
\hline Disbursements & 2,695 & 3,268 & 4,232 & 3,776 & 3,959 & 3,607 & 3,736 & 4,162 & 4,162 \\
\hline Amortizations & $-2,249$ & $-2,130$ & $-2,571$ & $-2,194$ & $-2,596$ & $-1,728$ & $-1,663$ & $-1,689$ & $-1,739$ \\
\hline Other External & -75 & -75 & -50 & 0 & 0 & 0 & 0 & 0 & 0 \\
\hline Domestic & $-4,471$ & $-2,856$ & $-4,938$ & $-1,700$ & -985 & $-2,164$ & $-2,741$ & $-3,054$ & $-3,138$ \\
\hline Banking system & $-5,670$ & $-3,328$ & $-6,488$ & $-2,954$ & -985 & $-2,164$ & $-2,741$ & $-3,054$ & $-3,138$ \\
\hline Of which: Central Bank & $-5,726$ & $-3,081$ & $-6,052$ & $-3,229$ & -985 & $-2,164$ & $-2,741$ & $-3,054$ & $-3,138$ \\
\hline Commercial banks & 56 & -246 & -436 & 275 & 0 & 0 & 0 & 0 & 0 \\
\hline Pension funds & 1,149 & 741 & 0 & 1,255 & 0 & 0 & 0 & 0 & 0 \\
\hline Other domestic & 50 & -269 & 1,550 & 0 & 0 & 0 & 0 & 0 & 0 \\
\hline Memorandum Items: & & & & & & & & & \\
\hline Overall balance of the central administration & 1,764 & 1,633 & -368 & $-2,000$ & $\ldots$ & $\ldots$ & $\ldots$ & $\ldots$ & $\ldots$ \\
\hline Overall balance of subnational government & 1,757 & 1,154 & 633 & $\ldots$ & $\ldots$ & $\ldots$ & $\ldots$ & $\ldots$ & $\ldots$ \\
\hline Prefectures & 734 & 567 & 241 & $\ldots$ & $\ldots$ & $\ldots$ & $\ldots$ & $\ldots$ & $\ldots$ \\
\hline Municipalities & 1,023 & 587 & 393 & $\ldots$ & $\ldots$ & $\ldots$ & $\ldots$ & $\ldots$ & $\ldots$ \\
\hline Poverty spending & 12,384 & 14,618 & 16,944 & 17,248 & $\ldots$ & $\ldots$ & $\ldots$ & $\ldots$ & $\ldots$ \\
\hline Hydrocarbon related revenue 4/ & 9,378 & 9,601 & 15,443 & 11,558 & 13,999 & 15,497 & 16,688 & 16,440 & 17,665 \\
\hline Hydrocarbon balance & 9,347 & 8,711 & 15,390 & 10,722 & 9,817 & 12,709 & 13,900 & 13,652 & 14,877 \\
\hline
\end{tabular}

Sources: Bolivian authorities, and Fund staff estimates.

$1 /$ In 2007 the expenditure on universities was reclassified from other spending into its functional classification, increasing wages and salaries by 1,056 million .Bolivianos in that year 2/ Excludes part of Bonosol payments in 2007.

3/ Non-hydrocarbon revenue minus overall expenditure plus YPFB capital expenditure.

4/ Hydrocarbon related revenues are defined as IDH, royalties, and the operating balance of YPFB. 
Table 4. Bolivia: Summary Balance of Payments

(In millions of U.S. dollars, unless otherwise indicated)

\begin{tabular}{|c|c|c|c|c|c|c|c|c|c|}
\hline & & & & Est. & & & Proj. & & \\
\hline & 2006 & 2007 & 2008 & 2009 & 2010 & 2011 & 2012 & 2013 & 2014 \\
\hline Current account & 1,318 & 1,591 & 2,015 & 620 & 489 & 412 & 446 & 509 & 541 \\
\hline Trade balance & 1,060 & 1,004 & 1,467 & 445 & 332 & 356 & 429 & 475 & 437 \\
\hline Exports, f.o.b. & 3,875 & 4,458 & 6,448 & 4,831 & 5,527 & 6,029 & 6,366 & 6,705 & 7,028 \\
\hline Exports, c.i.f. & 4,246 & 4,860 & 6,978 & 5,335 & 6,061 & 6,613 & 6,949 & 7,319 & 7,671 \\
\hline Natural gas & 1,669 & 1,971 & 3,158 & 1,975 & 2,468 & 2,777 & 2,893 & 3,022 & 3,147 \\
\hline of which: To Brazil & 1,357 & 1,606 & 2,850 & 1,581 & 1,961 & 2,258 & 2,368 & 2,489 & 2,608 \\
\hline volume (mmm3 p/day) & 24.4 & 26.9 & 30.5 & 22.3 & 24.0 & 27.0 & 28.0 & 29.0 & 30.0 \\
\hline price $(\$ / 000 \mathrm{cf} 3)$ & 4.3 & 4.6 & 7.2 & 5.5 & 6.3 & 6.5 & 6.6 & 6.7 & 6.7 \\
\hline To Argentina & 280 & 326 & 307 & 394 & 507 & 519 & 525 & 533 & 540 \\
\hline volume (mmm3 p/day) & 5.1 & 4.6 & 2.5 & 5.0 & 5.6 & 5.6 & 5.6 & 5.6 & 5.6 \\
\hline price $(\$ / 000 \mathrm{cf} 3)$ & 4.3 & 5.5 & 9.4 & 6.1 & 7.0 & 7.2 & 7.3 & 7.4 & 7.5 \\
\hline Mining & 1,061 & 1,387 & 1,940 & 1,763 & 1,876 & 2,052 & 2,046 & 2,051 & 2,031 \\
\hline Soy - related $1 /$ & 237 & 277 & 329 & 543 & 539 & 541 & 585 & 639 & 672 \\
\hline Other & 1,279 & 1,225 & 1,552 & 1,055 & 1,178 & 1,243 & 1,424 & 1,608 & 1,821 \\
\hline Imports, c.i.f. & $-2,814$ & $-3,455$ & $-4,980$ & $-4,386$ & $-5,195$ & $-5,673$ & $-5,937$ & $-6,230$ & $-6,591$ \\
\hline Services (net) & -168 & -189 & -200 & -245 & -315 & -393 & -443 & -474 & -508 \\
\hline Income (net) & -397 & -489 & -536 & -598 & -609 & -675 & -728 & -739 & -733 \\
\hline Of which: interest due on external public sector deb & -133 & -109 & -111 & -98 & -119 & -116 & -114 & -120 & -128 \\
\hline Of which: investment income (net) & -389 & -641 & -678 & -651 & -658 & -717 & -767 & -782 & -782 \\
\hline Transfers (net) & 822 & 1,266 & 1,284 & 1,018 & 1,081 & 1,124 & 1,187 & 1,246 & 1,345 \\
\hline Of which: HIPC assistance from grants & 44 & 2 & 3 & 2 & 0 & 0 & 0 & 0 & 0 \\
\hline Capital and financial account & 198 & 361 & 359 & -59 & -75 & -93 & -129 & -146 & -178 \\
\hline Capital transfers $2 /$ & 1,813 & 1,180 & 10 & 0 & 0 & 0 & 0 & 0 & 0 \\
\hline Direct investment (net) & 281 & 366 & 513 & 274 & 246 & 298 & 309 & 300 & 280 \\
\hline Gross investment & 582 & 953 & 1,302 & 709 & 846 & 848 & 859 & 850 & 830 \\
\hline Disinvestment and investment abroad & -301 & -587 & -789 & -435 & -600 & -550 & -550 & -550 & -550 \\
\hline Portfolio investment (net) & 25 & -30 & -208 & -444 & -219 & -230 & -255 & -260 & -265 \\
\hline Public sector & $-1,543$ & $-1,067$ & 231 & 423 & 195 & 269 & 297 & 354 & 347 \\
\hline Disbursements & 337 & 410 & 588 & 542 & 568 & 517 & 536 & 597 & 597 \\
\hline Amortization & $-1,880$ & $-1,477$ & -357 & -341 & -373 & -249 & -239 & -243 & -250 \\
\hline Other $3 /$ & 0 & 0 & 0 & 222 & 0 & 0 & 0 & 0 & 0 \\
\hline Fin system net foreign assets, excl. liquid asset requir & -109 & 127 & 0 & -314 & -102 & -160 & -200 & -240 & -240 \\
\hline Nonbank private sector loans & -25 & -52 & -21 & -26 & -150 & -170 & -180 & -180 & -180 \\
\hline Other, including errors and omissions & -242 & -159 & -160 & 28 & -279 & -100 & -100 & -120 & -120 \\
\hline Overall balance & 1,516 & 1,952 & 2,374 & 561 & 414 & 319 & 316 & 363 & 363 \\
\hline Financing & $-1,516$ & $-1,952$ & $-2,374$ & -561 & -414 & -319 & -316 & -363 & -363 \\
\hline Memorandum items: & & & & & & & & & \\
\hline Current account (percent of GDP) & 11.4 & 12.0 & 12.1 & 3.5 & 2.6 & 2.0 & 2.0 & 2.2 & 2.2 \\
\hline Merchandise exports (percent of GDP) & 33.6 & 33.5 & 38.8 & 27.4 & 29.0 & 29.4 & 29.0 & 28.6 & 28.1 \\
\hline Merchandise imports (percent of GDP) & -24.4 & -26.0 & -30.0 & -24.9 & -27.2 & -27.6 & -27.1 & -26.6 & -26.3 \\
\hline Gross official reserves (end-of-period) & 3,193 & 5,319 & 7,722 & 8,843 & 9,257 & 9,576 & 9,892 & 10,256 & 10,618 \\
\hline (In months of imports of goods and services) & 13.6 & 18.5 & 18.6 & 24.2 & 21.4 & 20.3 & 20.0 & 19.8 & 19.3 \\
\hline GDP (in millions of U.S. dollars) & 11,526 & 13,292 & 16,602 & 17,627 & 19,086 & 20,520 & 21,928 & 23,430 & 25,045 \\
\hline
\end{tabular}

Sources: Central Bank of Bolivia; and Fund staff estimates and projections.

1/ Excluding reexports.

2/ In 2006 includes effect of MDRI debt relief from the IMF and the World Bank equivalent to US\$1804.3 million.

In 2007 includes effect of MDRI relief from IADB equivalent to US\$ 1099 million.

3/ Includes SRD allocation in 2009. 
Table 5. Bolivia: Central Bank of Bolivia 1/

\begin{tabular}{|c|c|c|c|c|c|c|}
\hline & 2005 & 2006 & 2007 & 2008 & $\begin{array}{r}\text { Est. } \\
2009\end{array}$ & $\begin{array}{l}\text { Proj. } \\
2010\end{array}$ \\
\hline \multicolumn{7}{|c|}{ (Flows in millions of Bolivianos, unless otherwise indicated) } \\
\hline $\begin{array}{l}\text { Net international reserves } 2 / \\
\text { (Flows in millions of U.S. dollars) }\end{array}$ & $\begin{array}{r}4,105 \\
503\end{array}$ & $\begin{array}{r}10,270 \\
1,289\end{array}$ & $\begin{array}{r}15,491 \\
1,999\end{array}$ & $\begin{array}{r}17,449 \\
2,400\end{array}$ & $\begin{array}{r}2,372 \\
340\end{array}$ & $\begin{array}{r}2,788 \\
414\end{array}$ \\
\hline Net domestic assets & $-2,208$ & $-7,676$ & $-10,162$ & $-14,711$ & $-2,018$ & $-1,224$ \\
\hline Net credit to the nonfinancial public sector & $-1,543$ & $-5,725$ & $-2,993$ & $-6,055$ & $-3,489$ & -985 \\
\hline Net credit to financial intermediaries & -604 & $-1,620$ & $-6,131$ & $-8,974$ & 1,078 & -244 \\
\hline Of which: Open market operations (increase -) 3/ & -168 & $-1,171$ & $-5,397$ & $-6,745$ & 5,130 & $-2,147$ \\
\hline Net medium- and long-term foreign liabilities (increase -) & 8 & 5 & 6 & -12 & 8 & 5 \\
\hline Other items (net) $2 /$ & -69 & -336 & $-1,044$ & 329 & 385 & 0 \\
\hline Currency issue & 1,897 & 2,594 & 5,329 & 2,940 & 354 & 1,564 \\
\hline \multicolumn{7}{|c|}{ (Stocks in millions of Bolivianos, unless otherwise indicated) } \\
\hline $\begin{array}{l}\text { Net international reserves } \\
\text { (Stocks in millions of U.S. dollars) }\end{array}$ & $\begin{array}{r}12,785 \\
1,568\end{array}$ & $\begin{array}{r}24,291 \\
3,050\end{array}$ & $\begin{array}{r}40,705 \\
5,252\end{array}$ & $\begin{array}{r}56,215 \\
7,732\end{array}$ & $\begin{array}{r}57,196 \\
8,206\end{array}$ & $\begin{array}{r}59,984 \\
8,606\end{array}$ \\
\hline Net domestic assets & $-6,605$ & $-15,517$ & $-26,602$ & $-39,172$ & $-39,799$ & $-41,023$ \\
\hline Net credit to the nonfinancial public sector & 236 & $-6,952$ & $-9,337$ & $-14,096$ & $-15,064$ & $-16,049$ \\
\hline Net credit to financial intermediaries & 627 & $-1,455$ & $-7,906$ & $-17,461$ & $-18,016$ & $-18,260$ \\
\hline Of which: Open market operations $3 /$ & -690 & $-1,868$ & $-7,290$ & $-14,469$ & $-10,828$ & $-12,975$ \\
\hline $\begin{array}{l}\text { Net medium- and long-term foreign liabilities } \\
\text { Other items (net) }\end{array}$ & $\begin{array}{r}-220 \\
-7,248\end{array}$ & $\begin{array}{r}-212 \\
-6,898\end{array}$ & $\begin{array}{r}-207 \\
-9,152\end{array}$ & $\begin{array}{r}-214 \\
-7,401\end{array}$ & $\begin{array}{l}-1,967 \\
-4,753\end{array}$ & $\begin{array}{l}-1,962 \\
-4,753\end{array}$ \\
\hline Currency issue & 6,180 & 8,774 & 14,103 & 17,043 & 17,397 & 18,961 \\
\hline \multicolumn{7}{|c|}{ (Changes in percent of beginning-of-period currency issue) } \\
\hline Net international reserves & 95.8 & 166.2 & 176.6 & 123.7 & 13.9 & 16.0 \\
\hline Net domestic assets & -51.6 & -124.2 & -115.8 & -104.3 & -11.8 & -7.0 \\
\hline Net credit to the nonfinancial public sector & -36.0 & -92.6 & -34.1 & -42.9 & -20.5 & -5.7 \\
\hline Net credit to financial private sector & -14.1 & -26.2 & -69.9 & -63.6 & 6.3 & -1.4 \\
\hline Of which: Open market operations (increase -) 3/ & -3.9 & -19.0 & -61.5 & -47.8 & 30.1 & -12.3 \\
\hline Net medium- and long-term foreign liabilities (increase -) & 0.2 & 0.1 & 0.1 & -0.1 & 0.0 & 0.0 \\
\hline Other items (net) & -1.6 & -5.4 & -11.9 & 2.3 & 2.3 & 0.0 \\
\hline Currency issue & 44.3 & 42.0 & 60.7 & 20.9 & 2.1 & 9.0 \\
\hline \multicolumn{7}{|l|}{ Memorandum items: } \\
\hline Currency issue (average stock in percent of GDP) & 5.6 & 7.1 & 9.8 & 12.7 & 14.3 & 14.8 \\
\hline Net international reserves $4 /$ & 1,714 & 3,178 & 5,319 & 7,722 & $\ldots$ & $\ldots$ \\
\hline NIR coverage of broad money (percent) 4/ & 39.4 & 61.9 & 75.1 & 84.7 & $\ldots$ & $\ldots$ \\
\hline
\end{tabular}

Sources: Central Bank of Bolivia; and Fund staff estimates.

$1 /$ Stocks and flows in foreign currency are valued at accounting exchange rates for 2005 and at the beginning of period exchange rate for 2006 onwards.

2/ Includes valuation adjustments.

$3 /$ Includes direct placements to individuals

4/ All foreign assets valued at market prices. 
Table 6. Bolivia: Financial System Survey 1/ 2/

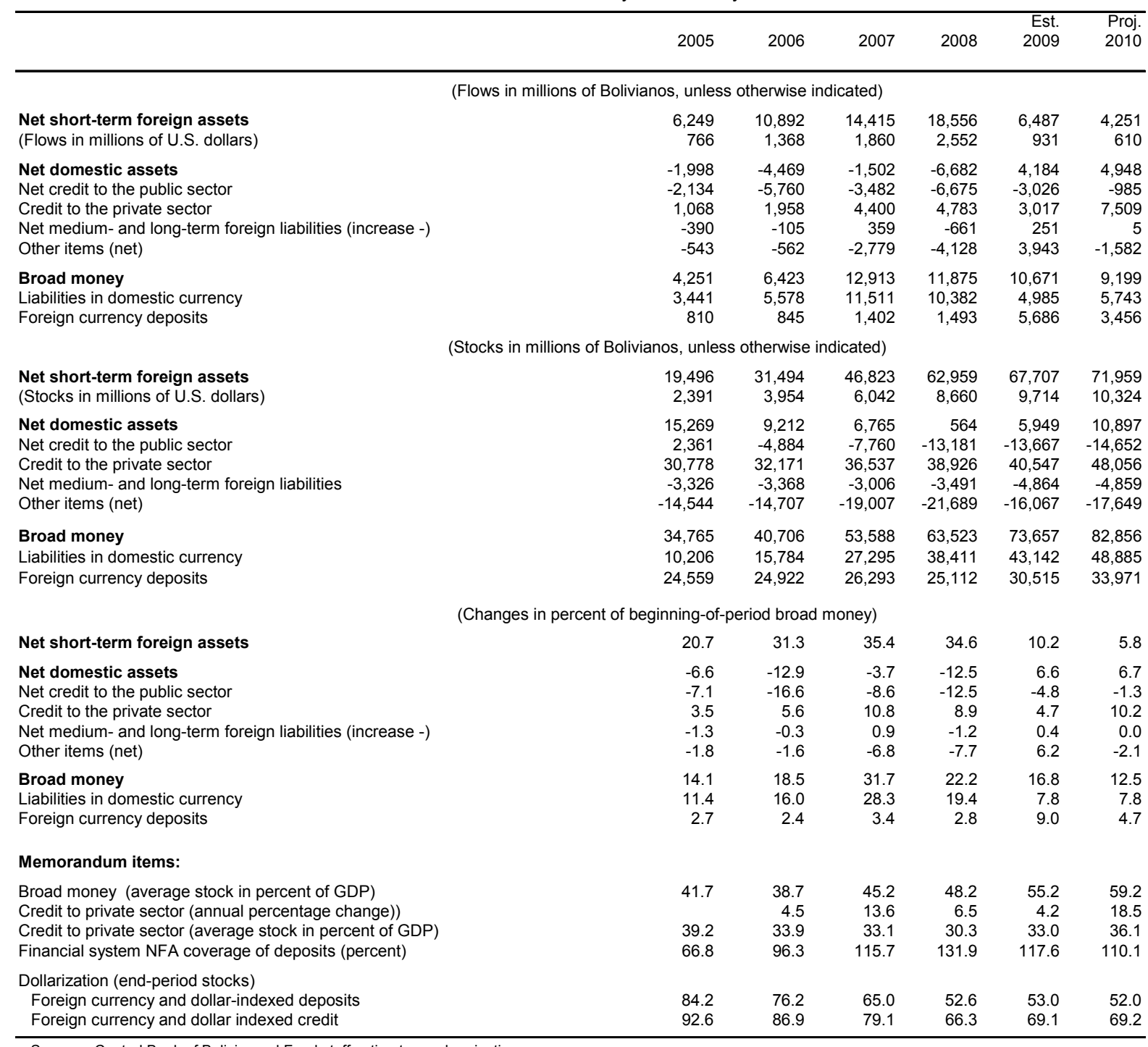

Sources: Central Bank of Bolivia; and Fund staff estimates and projections.

1/ The financial system comprises the central bank; commercial banks and nonbanks; and the National Financial Institution of Bolivia and FONDESIF, which are state-owned second-tier banks.

2/ Stocks and flows in foreign currency are valued at accounting exchange rates for 2005 and at the beginning of period exchange rate for 2006 onwards. 
Table 7. Bolivia: Consolidated Commercial Banks and Non-bank Depository Institutions 1/

\begin{tabular}{|c|c|c|c|c|c|c|}
\hline & 2005 & 2006 & 2007 & 2008 & $\begin{aligned} \text { Est. } \\
2009\end{aligned}$ & $\begin{array}{l}\text { Proj. } \\
2010\end{array}$ \\
\hline \multicolumn{7}{|c|}{ (Flows in millions of Bolivianos, unless otherwise indicated) } \\
\hline $\begin{array}{l}\text { Net short-term foreign assets } \\
\text { (Flow in millions of U.S. dollars) }\end{array}$ & $\begin{array}{r}2,144 \\
263\end{array}$ & $\begin{array}{r}622 \\
78\end{array}$ & $\begin{array}{r}-1,076 \\
-139\end{array}$ & $\begin{array}{r}1,107 \\
152\end{array}$ & $\begin{array}{r}4,115 \\
590\end{array}$ & $\begin{array}{r}1,463 \\
210\end{array}$ \\
\hline Net domestic assets & 378 & 3,383 & 8,884 & 8,077 & 6,281 & 6,290 \\
\hline Net credit to the public sector & -590 & -35 & -490 & -619 & 462 & 0 \\
\hline Credit to the private sector & 1,068 & 1,958 & 4,400 & 4,783 & 3,017 & 7,509 \\
\hline Net position with the central bank & 614 & 1,842 & 4,753 & 5,973 & 27 & 363 \\
\hline Net medium- and long-term foreign liabilities (increase -) & -398 & -110 & 354 & -650 & 243 & 0 \\
\hline Other items (net) & -315 & -272 & -134 & $-1,409$ & 2,532 & $-1,582$ \\
\hline Deposits & 2,522 & 4,005 & 7,808 & 9,185 & 10,397 & 7,753 \\
\hline Local currency deposits & 1,712 & 3,160 & 6,406 & 7,692 & 4,711 & 4,297 \\
\hline Foreign currency deposits & 810 & 845 & 1,402 & 1,493 & 5,686 & 3,456 \\
\hline \multicolumn{7}{|c|}{ (Stocks in millions of Bolivianos, unless otherwise indicated) } \\
\hline $\begin{array}{l}\text { Net short-term foreign assets } \\
\text { (Stock in millions of U.S. dollars) }\end{array}$ & $\begin{array}{r}6,712 \\
823\end{array}$ & $\begin{array}{r}7,203 \\
904\end{array}$ & $\begin{array}{r}6,118 \\
789\end{array}$ & $\begin{array}{r}6,744 \\
928\end{array}$ & $\begin{array}{r}10,511 \\
1,508\end{array}$ & $\begin{array}{r}11,974 \\
1,718\end{array}$ \\
\hline Net domestic assets & 22,459 & 25,491 & 34,352 & 40,972 & 47,064 & 53,354 \\
\hline Net credit to the public sector & 2,125 & 2,068 & 1,577 & 914 & 1,397 & 1,397 \\
\hline Credit to the private sector & 30,778 & 32,171 & 36,537 & 38,926 & 40,547 & 48,056 \\
\hline Net position with the central bank & 250 & 2,128 & 6,883 & 13,137 & 14,082 & 14,445 \\
\hline Net medium- and long-term foreign liabilities & $-3,106$ & $-3,156$ & $-2,798$ & $-3,277$ & $-2,897$ & $-2,897$ \\
\hline Other items (net) & $-7,588$ & $-7,721$ & $-7,846$ & $-8,729$ & $-6,066$ & $-7,648$ \\
\hline Deposits & 29,171 & 32,694 & 40,470 & 47,715 & 57,575 & 65,328 \\
\hline Local currency deposits & 4,611 & 7,771 & 14,177 & 22,604 & 27,060 & 31,357 \\
\hline Foreign currency deposits & 24,559 & 24,922 & 26,293 & 25,112 & 30,515 & 33,971 \\
\hline \multicolumn{7}{|c|}{ (Changes in percent of deposits at the beginning of the period) } \\
\hline Net short-term foreign assets & 8.2 & 2.1 & -3.3 & 2.7 & 8.6 & 2.5 \\
\hline Net domestic assets & 1.4 & 11.6 & 27.2 & 20.0 & 13.2 & 10.9 \\
\hline Net credit to the public sector & -2.2 & -0.1 & -1.5 & -1.5 & 1.0 & 0.0 \\
\hline Credit to the private sector & 4.1 & 6.7 & 13.5 & 11.8 & 6.3 & 13.0 \\
\hline Net position with the central bank & 2.3 & 6.3 & 14.5 & 14.8 & 0.1 & 0.6 \\
\hline Net medium- and long-term foreign liabilities (increase -) & -1.5 & -0.4 & 1.1 & -1.6 & 0.5 & 0.0 \\
\hline Other items (net) & -1.2 & -0.9 & -0.4 & -3.5 & 5.3 & -2.7 \\
\hline Deposits & 9.6 & 13.7 & 23.9 & 22.7 & 21.8 & 13.5 \\
\hline Local currency deposits & 6.5 & 10.8 & 19.6 & 19.0 & 9.9 & 7.5 \\
\hline Foreign currency deposits & 3.1 & 2.9 & 4.3 & 3.7 & 11.9 & 6.0 \\
\hline \multicolumn{7}{|l|}{ Memorandum items: } \\
\hline Credit to private sector (average stock in percent of GDP) & 39.2 & 33.9 & 33.1 & 30.3 & 33.0 & 36.1 \\
\hline NFA coverage of dollar deposits (percent) & 23.0 & 22.0 & 15.1 & 14.1 & 18.3 & 18.3 \\
\hline U.S. dollar and dollar-indexed deposits (in percent of total deposits) & 84.2 & 76.2 & 65.0 & 52.6 & 53.0 & 52.0 \\
\hline U.S. dollar and dollar indexed credit (in percent of total credit) & 92.6 & 86.9 & 79.1 & 66.3 & 69.1 & 69.2 \\
\hline
\end{tabular}

Sources: Central Bank of Bolivia; and Fund staff estimates.

1 Stocks and flows in foreign currency are valued at accounting exchange rates for 2005 and at the beginning of period exchange rate for 2006 onwards. 
Table 8. Bolivia: Selected Vulnerability Indicators

\begin{tabular}{|c|c|c|c|c|c|}
\hline & 2005 & 2006 & 2007 & 2008 & $\begin{array}{r}\text { Sep } \\
2009 \\
\end{array}$ \\
\hline Reserve adequacy & \multicolumn{5}{|c|}{ (In US\$ million, unless otherwise indicated) } \\
\hline $\begin{array}{l}\text { Net international reserves } 1 / \\
\text { NIR coverage, in percent of: }\end{array}$ & 1,714 & 3,178 & 5,319 & 7,722 & 8,453 \\
\hline Dollar deposits & 56.9 & 101.6 & 156.8 & 223.6 & 193.1 \\
\hline Total deposits & 47.9 & 77.4 & 101.9 & 117.7 & 102.3 \\
\hline Broad money & 39.4 & 61.9 & 75.1 & 98.1 & 80.0 \\
\hline In months of imports of goods and services & 5.9 & 9.2 & 11.2 & 18.1 & 16.9 \\
\hline $\begin{array}{l}\text { Net foreign assets of the financial system } \\
\text { NFA coverage, in percent of: }\end{array}$ & 2,391 & 3,954 & 6,042 & 8,660 & 9,664 \\
\hline Dollar deposits & 79.4 & 126.4 & 178.1 & 250.7 & 220.7 \\
\hline Total deposits & 66.8 & 96.3 & 115.7 & 131.9 & 123.1 \\
\hline Broad money & 56.1 & 77.4 & 87.4 & 99.1 & 97.5 \\
\hline Debt ratios $2 /$ & \multicolumn{5}{|c|}{ (In percent of GDP) } \\
\hline Total gross NFPS debt & 80.4 & 55.2 & 40.9 & 37.5 & 39.4 \\
\hline Domestic & 30.7 & 27.1 & 24.9 & 23.2 & 24.1 \\
\hline External & 49.6 & 28.2 & 16.1 & 14.3 & 15.3 \\
\hline Total net NFPS debt & 71.1 & 41.9 & 26.8 & 20.6 & 19.6 \\
\hline Private external debt & 13.4 & 10.2 & 9.3 & 7.7 & 7.3 \\
\hline Net International Investment Position & -75.4 & -31.4 & -5.2 & 9.3 & $\ldots$ \\
\hline \multicolumn{6}{|l|}{ Commodity dependency } \\
\hline Hydrocarbon revenue (in percent of total revenues)1/ & 23.4 & 33.0 & 30.0 & 40.6 & 30.9 \\
\hline Non-hydrocarbon fiscal balance (in percent of GDP)1/ & -8.9 & -5.7 & -5.9 & -8.4 & -8.3 \\
\hline Gas exports (in percent of total exports) & 38.9 & 43.1 & 44.2 & 49.0 & 49.9 \\
\hline Mining exports (in percent of total exports) & 19.5 & 27.4 & 31.1 & 30.1 & 36.5 \\
\hline \multicolumn{6}{|l|}{ Banking sector indicators $3 /$} \\
\hline Nonperforming loans (in percent of total loans) & 11.3 & 8.7 & 5.6 & 4.3 & 4.1 \\
\hline Restructured loans (in percent of total loans) & 22.5 & 16.2 & 10.7 & 7.1 & 5.6 \\
\hline Nonperforming and restructured loans (in percent of total loans) & 33.8 & 24.9 & 16.3 & 11.4 & 9.7 \\
\hline Capital adequacy ratio & 14.7 & 13.3 & 12.6 & 13.7 & 13.4 \\
\hline Profits after tax (in percent of equity) & 6.4 & 13.3 & 21.2 & 20.3 & 19.7 \\
\hline Cash and short-term investments as percent of total assets & 30.7 & 33.9 & 35.2 & 43.4 & 48.3 \\
\hline Composition of bank deposits & \multicolumn{5}{|c|}{ (In percent) } \\
\hline Dollar deposits & 84.2 & 76.2 & 65.0 & 52.6 & 55.8 \\
\hline Inflation-indexed deposits & 2.1 & 3.3 & 4.2 & 5.0 & 0.0 \\
\hline Local currency deposits & 13.7 & 20.5 & 30.9 & 42.4 & 44.2 \\
\hline \multicolumn{6}{|l|}{ Memorandum items: } \\
\hline Fiscal balance (in percent of GDP) $2 /$ & -2.2 & 4.5 & 2.6 & 4.3 & 0.4 \\
\hline $\begin{array}{l}\text { Total financial system deposits (US\$ million) } \\
\text { of which: }\end{array}$ & 3,578 & 4,105 & 5,222 & 6,563 & 7,853 \\
\hline Sight deposits & 934 & 1,099 & 1,371 & 1,409 & 1,731 \\
\hline Savings deposits & 928 & 1,193 & 1,744 & 2,064 & 2,355 \\
\hline
\end{tabular}

Sources: Central Bank of Bolivia; and Fund staff estimates and projections.

1/ Foreign assets valued at market prices.

2/ Debt and fiscal figures are end-2009 projections. Fiscal balance excludes nationalization costs.

3/ As of October 31, 2009. 
Table 9. Bolivia: Millennium Development Goals

\begin{tabular}{|c|c|c|c|c|c|c|}
\hline & $\begin{array}{c}\text { First } \\
\text { Observation }\end{array}$ & 2004 & 2005 & 2006 & 2007 & $\begin{array}{r}\text { Target } \\
2015\end{array}$ \\
\hline \multicolumn{7}{|l|}{ Goal 1. Eradicate Extreme Poverty and Hunger } \\
\hline \multicolumn{7}{|c|}{$\begin{array}{l}\text { Target 1: Halve, between } 1990 \text { and 2015, the proportion of people whose income is less than one dollar a } \\
\text { day. }\end{array}$} \\
\hline Population below US $\$ 1$ a day (in percent) & $41.2(1990)$ & $\ldots$ & 36.7 & 37.7 & $\ldots$ & 24.1 \\
\hline \multicolumn{7}{|c|}{ Target 2: Halve, between 1990 and 2015, the proportion of people suffering hunger } \\
\hline Prevalence of child malnutrition (percent of children under 3 ) & $38.3(1990)$ & $\begin{array}{r}25.5 \\
(2003)\end{array}$ & $\cdots$ & $\cdots$ & & 19.0 \\
\hline \multicolumn{7}{|l|}{ Goal 2. Achieve Universal Primary Education } \\
\hline \multicolumn{7}{|c|}{ Target 3 . Ensure that, by 2015 , children will be able to complete a full course of primary schooling. } \\
\hline Net primary enrollment ratio (percent of relevant age group) & & 94.0 & 94.5 & 92.7 & 93.7 & 100.0 \\
\hline Percentage of cohort reaching grade 8 & $55.4(1992)$ & 79.5 & 77.8 & 75.6 & $\cdots$ & 100.0 \\
\hline \multicolumn{7}{|l|}{ Goal 3. Promote Gender Equality and Empower Women } \\
\hline \multicolumn{7}{|c|}{$\begin{array}{l}\text { Target } 4 \text {. Eliminate gender disparity in primary and secondary education preferably by } 2005 \text { and to all } \\
\text { levels of education by } 2015 \text {. }\end{array}$} \\
\hline Gender disparities at completion of primary education (percent) & $6.6(1992)$ & $\ldots$ & 0.3 & -0.6 & $\ldots$ & 0.0 \\
\hline Gender disparities at completion of secondary education (percent) & $3.4(1992)$ & $\cdots$ & -0.4 & -1.5 & $\cdots$ & 0.0 \\
\hline \multicolumn{7}{|l|}{ Goal 4. Reduce Child Mortality } \\
\hline \multicolumn{7}{|c|}{ Target 5. Reduce by two-thirds, between 1990 and 2015 , the under five mortality rate } \\
\hline Infant mortality rate (per 1,000 live births) & $89(1990)$ & $\ldots$ & $\ldots$ & $\ldots$ & 47.6 & 30.0 \\
\hline Immunization against measles (percent of children under 12-months) & $68(1994)$ & $\ldots$ & 84.5 & 82.6 & $\ldots$ & 95.0 \\
\hline \multicolumn{7}{|l|}{ Goal 5. Improve Maternal Health } \\
\hline \multicolumn{7}{|c|}{ Target 6. Reduce by three-quarters, between 1990 and 2015 , the maternal mortality ratio. } \\
\hline Maternal mortality ratio (modeled estimate, per 100,000 live births) & $416(1990)$ & $\ldots$ & 290 & $\ldots$ & $\ldots$ & 104 \\
\hline Proportion of births attended by skilled health personnel (percent) & $27(1995)$ & 59.6 & 61.9 & 65.0 & $\cdots$ & 70.0 \\
\hline \multicolumn{7}{|l|}{ Goal 6. Combat HIVIAIDS, Malaria, and Other Diseases } \\
\hline \multicolumn{7}{|l|}{ Target 7 . Halt by 2015 , and begin to reverse, the spread of HIVIAIDS } \\
\hline HIV prevalence, total (percent ages 15-24) & $1.8(1990)$ & 13.4 & 19.3 & 19.2 & $\ldots$ & 13.0 \\
\hline \multicolumn{7}{|c|}{ Target 8 . Halt by 2015 , and begin to reverse, the incidence of malaria and other major diseases } \\
\hline Incidence of malaria (per 1,000 people) & $7.5(1990)$ & 4.1 & 5.5 & 5.2 & $\ldots$ & 2.0 \\
\hline Incidence of tuberculosis cases cured (percent of diagnosed) & $52.6(1995)$ & 80.3 & 78.5 & 82.9 & $\cdots$ & 95.0 \\
\hline \multicolumn{7}{|c|}{ Target 10. halve by 2015 proportion of people without access to safe drinking water } \\
\hline Access to potable water (percent of population) & $57.5(1992)$ & 72.3 & 71.7 & 73.1 & $\ldots$ & 78.5 \\
\hline Access to improved sanitation facilities (percent of population) & $28(1992)$ & 41.6 & 43.5 & 55.7 & $\cdots$ & 64.0 \\
\hline \multicolumn{7}{|l|}{ Goal 8. Develop a global Partnership for Development } \\
\hline \multicolumn{7}{|c|}{ Target 18. Make available new technologies, especially information and communications } \\
\hline Mobile and fixed-line telephone subscribers (per 100 people) & $2.7(1990)$ & 26.9 & 33.4 & 37.9 & 41.3 & $\ldots$ \\
\hline Internet users (per 100 people) & $0.1(1995)$ & 4.4 & 5.2 & 6.2 & 10.5 & $\cdots$ \\
\hline
\end{tabular}

Sources: Bolivian authorities; and World Bank Development Indicators. 


\section{AnNeX 1. SuMmary OF ANNEXeS}

The full annexes to this report may be viewed in CyberDocs on the Fund's intranet and on the secure extranet for Executive Directors and member country officials.

\section{Fund relations}

As of November 30, 2009, Bolivia did not have any outstanding purchases or loans. The latest SBA expired on March 31, 2006. The last Article IV consultation was completed by the Executive Board on January 14, 2009. The Bolivian exchange rate regime has been reclassified from a crawling peg to a stabilized arrangement against the U.S. dollar. Bolivia has received wide-ranging TA in recent years. Mr. Luis Breuer has been the IMF regional resident representative (based in Lima, Peru) since June 2009.

\section{Relations with the World Bank Group}

A new Interim Strategy Note (ISN) for FY10-11 was discussed and approved by the Board on June 2, 2009. The ISN has a total envelope of US\$137 million of IDA resources. The lending program amounts to US\$90 million in predefined operations while US\$47 million has been left available for flexible use, to respond to the unforeseen needs, support the Government's efforts to stem the impact of the global crisis, and to reduce extreme poverty. The World Bank's portfolio in Bolivia comprises 11 investment projects for a total amount of US\$302.8 million of which US\$190.6 remain undisbursed.

\section{Relations with the Inter-American Development Bank}

As of November 30, 2009, Bolivia's outstanding debt to the IDB was approximately US\$562 millions with undisbursed approved funds for US\$587.8 millions. Consistent with the application of the Debt Sustainability Framework and after the last round of debt relief, new IDB lending to Bolivia will be following newly adopted operational guidelines for concessional funds under the Fund of Special Operations performance-based allocation system. The Bank's 2009 operative program contains a portfolio of sovereign guaranteed operations of 6 loans for a total amount of US\$191 millions for the year, concentrated in water, housing and agricultural productivity sectors. An additional of 9 loans for US $\$ 200$ millions has been identified and are already in the Bank’s lending pipeline for the 2010 cycle.

\section{Statistical issues}

Data provision to the Fund has some shortcomings, but is broadly adequate for surveillance. A data ROSC mission in early 2007 confirmed advances in recent years, and reiterated the existence of shortcomings that might hamper the formulation of appropriate policies. Bolivia has participated in the GDDS since November 2000. 


\title{
INTERNATIONAL MONETARY FUND
}

\section{BOLIVIA}

\author{
External and Public Debt Sustainability Analysis \\ Prepared by the Staff of the International Monetary Fund ${ }^{1}$ \\ Approved by Antônio Furtado and Michele Shannon
}

December 23, 2009

Following MDRI debt relief, Bolivia's public debt sustainability has continued to improve as a result of overall fiscal surpluses, and the risk of debt distress is low. Debt ratios continue to display ample margins with respect to risk thresholds and are expected to decline further under the baseline scenario. Debt service is projected to remain low, reflecting predominantly long maturities of remaining stocks of both domestic and foreign debt. The path of debt ratios would deteriorate somewhat under standard stress tests, but would remain within manageable bounds over the medium- and long run.

\section{Background}

1. Bolivia's gross public debt (domestic and external) has fallen significantly over the last several years, benefiting from the MDRI and fiscal surpluses. Between 2004 and 2008, gross debt has fallen by 50 percentage points of GDP to 38 percent of GDP in 2008 . While multilateral external debt has fallen sharply, bilateral external debt has increased, driven by higher lending from South American countries, mainly Venezuela.

\section{Bolivia's changing debt structure and the accumulation of significant deposits} have further reduced debt vulnerabilities. Since 2005 , average maturities have been successfully extended and foreign currency exposure has been reduced. Moreover, with the accumulation of deposits of the non-financial public sector in the financial systemamounting to about 21 percent of GDP at present- the solvency of the public sector measured by the net public debt (i.e., gross debt minus those deposits) has improved even more significantly. On account of declining gross debt, net debt ratios would reach very low levels during the projection period.

\footnotetext{
${ }^{1}$ Since Bolivia is an IDA blend country, this DSA was not conducted jointly with the World Bank.
} 


\section{Baseline Scenario}

3. The main assumptions of the baseline scenario for the period 2009-29 are:

- $\quad$ Average annual real GDP growth: 4 percent until 2029. Potential growth is subject to significant upside risks, as discussed in Box 7 of the Staff Report.

- $\quad$ Average deflator inflation: 2.4 percent per year on average until 2014, in line with the recent medium-term staff projections, and would increase to 3.5 percent over the long term.

- $\quad$ Export and import growth: in line with the medium-term staff projections and the assumption of stable import and export ratios to GDP over the long term.

- $\quad$ Financing strategy: commercial debt is expected to remain nil, with CAF expected to remain as the main source of financing. Despite the overall balanced fiscal position, net external financing flows are expected to be positive until 2014. Likewise, complex intergovernmental fiscal relations may require some additional domestic financing. The excess funds at the level of the non-financial sector will continue to be accumulated as deposits.

- Average concessionality of the public sector borrowing: projected to evolve, in the medium-term, based on projected disbursements of official loans.

\section{Bolivia's public and external debt is expected to remain sustainable throughout the} projection period, and the risk of debt distress is low. Bolivia is classified as a medium performer in terms of its policy and institutional capacity, measured by the three-year average of the World Bank's Country Policy and Institutional Assessment (CPIA) scores. All the debt burden indicators for Bolivia are well below the specific indicative thresholds for medium performers.

\begin{tabular}{lcccccc}
\multicolumn{3}{c}{ Indicative Policy-Dependent Debt Thresholds for Medium Performers } \\
\hline & \multicolumn{3}{c}{ PV of debt, percent of } & & Debt service, percent of \\
\cline { 2 - 3 } Bolivia, 2009 & Exports & GDP & Revenue & & Exports & Revenue \\
\cline { 2 - 4 } Indicative thresholds & 150 & 14 & 44 & & 5 & 5 \\
\hline
\end{tabular}

Hence, Bolivia's risk of debt distress is low - an assessment that would hold even under significant stress tests. After a projected small deficit in 2010, the fiscal position would return to small surpluses in 20112014 , with an average overall surplus of about 0.4 percent of GDP, and would remain at this level throughout the projection period. Under the baseline scenario, Bolivia's indebtedness and debt service levels would remain very manageable. Specifically, the gross non-financial sector public debt-to-GDP ratio-39 percent in 2009-is projected to decline gradually to 34 percent by 2014, and to 14 percent in 2029. A temporary increase in 2009 is due to net external financing and additional domestic bond issuance despite an overall surplus. The 
total stock of external debt (public and private) is projected to fall to about 22 percent of GDP by 2014, and to stabilize around 9 percent of GDP by 2029 .

\section{Stress Tests}

4. Standard stress tests suggest that the sustainability of Bolivia's public and external indebtedness is resilient to a series of shocks. Under the most extreme stress test to external debt - a combined shock to debt concessionality, GDP growth, export growth, and external inflation - the ratio of the NPV of debt to GDP deteriorates somewhat and eventually returns to a downward trajectory. In all cases, it would remain well below risky levels. Flow indicators also remain manageable under all stress tests. For public debt, the biggest risk stems from a temporary or permanently lower GDP growth, however, tests indicate that ratios remain within manageable levels. 
Table 1a.Bolivia: Public Sector Debt Sustainability Framework, Baseline Scenario, 2006-2029

(In percent of GDP, unless otherwise indicated)

\begin{tabular}{|c|c|c|c|c|c|c|c|c|c|c|c|c|c|c|c|}
\hline & \multicolumn{3}{|c|}{ Actual } & \multirow[b]{2}{*}{ Average } & \multirow[b]{2}{*}{$\begin{array}{c}\text { Standard } \\
\text { Deviation } \\
\end{array}$} & \multicolumn{5}{|l|}{ Estimate } & \multicolumn{5}{|c|}{ Projections } \\
\hline & 2006 & 2007 & 2008 & & & 2009 & 2010 & 2011 & 2012 & 2013 & 2014 & $\begin{array}{l}2009-14 \\
\text { Average } \\
\end{array}$ & 2019 & 2029 & $\begin{array}{l}2015-29 \\
\text { Average } \\
\end{array}$ \\
\hline Public sector debt 1 / & 55.2 & 40.9 & 37.5 & & & 39.4 & 37.4 & 36.1 & 35.1 & 34.4 & 33.5 & & 24.3 & 14.2 & \\
\hline $\mathrm{o} / \mathrm{w}$ foreign-currency denominated & 37.4 & 25.0 & 21.6 & & & 22.1 & 21.3 & 21.0 & 20.9 & 20.9 & 20.8 & & 15.3 & 9.0 & \\
\hline Change in public sector debt & -25.1 & -14.3 & -3.5 & & & 1.9 & -2.0 & -1.3 & -1.0 & -0.7 & -0.8 & & -2.2 & -1.4 & \\
\hline Identified debt-creating flows & -20.0 & -11.0 & -10.9 & & & -0.8 & -2.8 & -2.7 & -2.7 & -2.5 & -2.5 & & -2.3 & -1.4 & \\
\hline Primary deficit & -7.0 & -5.1 & -6.4 & -0.1 & 5.4 & -2.7 & -1.9 & -2.3 & -2.5 & -2.3 & -2.3 & -2.3 & -1.9 & -1.7 & -1.8 \\
\hline Revenue and grants & 34.3 & 34.4 & 38.9 & & & 32.5 & 34.3 & 34.7 & 35.1 & 34.0 & 34.0 & & 35.6 & 32.3 & \\
\hline of which: grants & 1.8 & 1.6 & 1.2 & & & 1.0 & 1.1 & 1.1 & 1.1 & 1.1 & 1.1 & & 1.2 & 1.2 & \\
\hline Primary (noninterest) expenditure & 27.3 & 29.3 & 32.5 & & & 29.8 & 32.4 & 32.4 & 32.6 & 31.7 & 31.6 & & 33.7 & 30.6 & \\
\hline Automatic debt dynamics & -10.6 & -4.9 & -5.6 & & & 1.8 & -0.8 & -0.4 & -0.2 & -0.2 & -0.2 & & -0.4 & 0.2 & \\
\hline Contribution from interest rate/growth differential & -4.9 & -1.8 & -2.1 & & & 1.1 & -0.3 & -0.1 & 0.0 & 0.0 & 0.0 & & -0.1 & 0.4 & \\
\hline of which: contribution from average real interest rate & -1.2 & 0.6 & 0.3 & & & 2.3 & 1.2 & 1.3 & 1.4 & 1.4 & 1.3 & & 0.9 & 1.0 & \\
\hline of which: contribution from real GDP growth & -3.7 & -2.4 & -2.4 & & & -1.2 & -1.5 & -1.4 & -1.4 & -1.4 & -1.3 & & -1.0 & -0.6 & \\
\hline Contribution from real exchange rate depreciation & -5.6 & -3.0 & -3.5 & & & 0.7 & -0.5 & -0.3 & -0.2 & -0.2 & -0.2 & & $\ldots$ & $\ldots$ & \\
\hline Other identified debt-creating flows & -2.4 & -1.0 & 1.0 & & & 0.1 & -0.2 & 0.0 & 0.0 & 0.0 & 0.0 & & 0.0 & 0.0 & \\
\hline Privatization receipts (negative) & 0.0 & 0.8 & 1.6 & & & 0.3 & 0.0 & 0.0 & 0.0 & 0.0 & 0.0 & & 0.0 & 0.0 & \\
\hline Recognition of implicit or contingent liabilities & 0.0 & 0.0 & 0.0 & & & 0.0 & 0.0 & 0.0 & 0.0 & 0.0 & 0.0 & & 0.0 & 0.0 & \\
\hline Debt relief (HIPC and other) & -2.4 & -1.8 & -0.5 & & & -0.2 & -0.2 & 0.0 & 0.0 & 0.0 & 0.0 & & 0.0 & 0.0 & \\
\hline Other (specify, e.g. bank recapitalization) & 0.0 & 0.0 & 0.0 & & & 0.0 & 0.0 & 0.0 & 0.0 & 0.0 & 0.0 & & 0.0 & 0.0 & \\
\hline Residual, including asset changes & -5.2 & -3.3 & 7.5 & & & 2.7 & 0.9 & 1.4 & 1.7 & 1.8 & 1.7 & & 0.0 & 0.0 & \\
\hline \multicolumn{16}{|l|}{ Other Sustainability Indicators } \\
\hline$P V$ of public sector debt & 29.9 & 26.5 & 36.3 & & & 39.5 & 39.4 & 39.2 & 39.1 & 39.4 & 39.4 & & 34.3 & 20.6 & \\
\hline $\mathrm{o} / \mathrm{w}$ foreign-currency denominated & 12.1 & 10.5 & 20.4 & & & 22.2 & 23.3 & 24.1 & 24.8 & 25.9 & 26.7 & & 25.3 & 15.4 & \\
\hline $\mathrm{o} / \mathrm{w}$ external & $\ldots$ & $\ldots$ & 11.6 & & & 13.9 & 15.7 & 17.0 & 18.2 & 19.6 & 20.8 & & 21.2 & 13.0 & \\
\hline PV of contingent liabilities (not included in public sector debt) & $\ldots$ & $\ldots$ & $\ldots$ & & & $\ldots$ & $\ldots$ & $\ldots$ & $\ldots$ & $\ldots$ & $\ldots$ & & & . & \\
\hline Gross financing need $2 /$ & 5.6 & 9.8 & 3.6 & & & 5.0 & 5.6 & 4.8 & 4.4 & 4.4 & 4.3 & & 3.9 & 3.3 & \\
\hline $\mathrm{PV}$ of public sector debt-to-revenue and grants ratio (in percent) & 87.1 & 76.9 & 93.3 & & & 121.4 & 114.9 & 112.9 & 111.4 & 115.7 & 116.0 & & 96.5 & 63.7 & \\
\hline $\mathrm{PV}$ of public sector debt-to-revenue ratio (in percent) & 92.1 & 80.8 & 96.4 & & & 125.3 & 118.7 & 116.6 & 115.0 & 119.5 & 119.9 & & 99.9 & 66.2 & \\
\hline o/w external 3/ & & & 30.9 & & & 44.1 & 47.2 & 50.6 & 53.5 & 59.6 & 63.4 & & 61.7 & 41.9 & \\
\hline Debt service-to-revenue and grants ratio (in percent) 4/ & 22.4 & 35.3 & 21.9 & & & 14.7 & 13.3 & 12.5 & 12.0 & 11.9 & 11.8 & & 10.4 & 11.7 & \\
\hline Debt service-to-revenue ratio (in percent) 4 / & 23.6 & 37.0 & 22.6 & & & 15.2 & 13.8 & 12.9 & 12.3 & 12.3 & 12.1 & & 10.7 & 12.1 & \\
\hline Primary deficit that stabilizes the debt-to-GDP ratio & 18.1 & 9.2 & -2.9 & & & -4.6 & 0.1 & -1.0 & -1.5 & -1.6 & -1.5 & & 0.4 & -0.2 & \\
\hline \multicolumn{16}{|l|}{ Key macroeconomic and fiscal assumptions } \\
\hline Real GDP growth (in percent) & 4.8 & 4.6 & 6.1 & 3.8 & 2.3 & 3.3 & 4.0 & 4.0 & 4.0 & 4.0 & 4.0 & 3.9 & 4.0 & 4.0 & 4.0 \\
\hline Average nominal interest rate on forex debt (in percent) & 3.5 & 4.8 & 5.7 & 4.1 & 1.1 & 6.1 & 5.7 & 6.0 & 6.0 & 6.0 & 6.1 & 6.0 & 6.5 & 8.3 & 7.1 \\
\hline Average real interest rate on domestic debt (in percent) & -6.8 & 0.0 & -2.7 & -2.0 & 2.9 & 8.9 & 2.6 & 3.3 & 3.9 & 4.0 & 3.9 & 4.4 & 1.8 & 7.1 & 3.4 \\
\hline Real exchange rate depreciation (in percent, + indicates depreciation) & -10.0 & -8.3 & -14.5 & -4.0 & 7.9 & 3.1 & $\ldots$ & 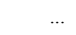 & $\ldots$ & $\ldots$ & $\ldots$ & $\ldots$ & $\ldots$ & $\ldots$ & $\ldots$ \\
\hline Inflation rate (GDP deflator, in percent) & 13.7 & 7.4 & 10.4 & 7.5 & 3.6 & -1.5 & 4.1 & 3.4 & 2.8 & 2.7 & 2.8 & 2.4 & 3.5 & 3.5 & 3.5 \\
\hline Growth of real primary spending (deflated by GDP deflator, in percent) & -0.1 & 0.1 & 0.2 & 0.1 & 0.1 & -0.1 & 0.1 & 0.0 & 0.0 & 0.0 & 0.0 & 0.0 & 0.0 & 0.0 & 0.0 \\
\hline Grant element of new external borrowing (in percent) & $\ldots$ & $\ldots$ & $\ldots$ & $\ldots$ & $\ldots$ & 8.3 & 10.6 & 13.3 & 15.6 & 15.2 & 13.9 & 12.8 & 12.4 & 10.8 & . \\
\hline
\end{tabular}

Sources: Country authorities; and staff estimates and projections.

2/ Gross financing need is defined as the primary deficit plus debt service plus the stock of short-term debt at the end of the last period.

/ Revenues excluding grants.

(1) of inest and a

$5 /$ Historical averages and standard deviations are generally derived over the past 10 years, subject to data availability. 
Table 2a.Bolivia: Sensitivity Analysis for Key Indicators of Public Debt 2009-2029

\begin{tabular}{|c|c|c|c|c|c|c|c|c|}
\hline & \multicolumn{8}{|c|}{ Projections } \\
\hline & 2009 & 2010 & 2011 & 2012 & 2013 & 2014 & 2019 & 2029 \\
\hline \multicolumn{9}{|c|}{ PV of Debt-to-GDP Ratio } \\
\hline Baseline & 39 & 39 & 39 & 39 & 39 & 39 & 34 & 21 \\
\hline \multicolumn{9}{|l|}{ A. Alternative scenarios } \\
\hline A1. Real GDP growth and primary balance are at historical averages & 39 & 41 & 43 & 45 & 48 & 50 & 52 & 47 \\
\hline A2. Primary balance is unchanged from 2009 & 39 & 38 & 38 & 37 & 37 & 37 & 28 & 7 \\
\hline A3. Permanently lower GDP growth 1 / & 39 & 40 & 40 & 40 & 41 & 42 & 44 & 50 \\
\hline \multicolumn{9}{|l|}{ B. Bound tests } \\
\hline B1. Real GDP growth is at historical average minus one standard deviations in 2010-2011 & 39 & 41 & 43 & 45 & 47 & 48 & 50 & 45 \\
\hline B2. Primary balance is at historical average minus one standard deviations in $2010-2011$ & 39 & 46 & 53 & 53 & 53 & 52 & 45 & 28 \\
\hline B3. Combination of B1-B2 using one half standard deviation shocks & 39 & 44 & 49 & 50 & 51 & 51 & 48 & 38 \\
\hline B4. One-time 30 percent real depreciation in 2010 & 39 & 50 & 50 & 50 & 51 & 51 & 47 & 32 \\
\hline B5. 10 percent of GDP increase in other debt-creating flows in 2010 & 39 & 49 & 49 & 48 & 48 & 48 & 41 & 25 \\
\hline \multicolumn{9}{|c|}{ PV of Debt-to-Revenue Ratio 2/ } \\
\hline Baseline & 121 & 115 & 113 & 111 & 116 & 116 & 97 & 64 \\
\hline \multicolumn{9}{|l|}{ A. Alternative scenarios } \\
\hline A1. Real GDP growth and primary balance are at historical averages & 121 & 120 & 124 & 129 & 140 & 146 & 145 & 147 \\
\hline A2. Primary balance is unchanged from 2009 & 121 & 112 & 109 & 106 & 109 & 108 & 79 & 22 \\
\hline A3. Permanently lower GDP growth $1 /$ & 121 & 116 & 115 & 115 & 121 & 124 & 123 & 155 \\
\hline \multicolumn{9}{|l|}{ B. Bound tests } \\
\hline B1. Real GDP growth is at historical average minus one standard deviations in 2010-2011 & 121 & 120 & 125 & 128 & 137 & 141 & 139 & 138 \\
\hline B2. Primary balance is at historical average minus one standard deviations in 2010-2011 & 121 & 135 & 154 & 151 & 155 & 154 & 126 & 86 \\
\hline B3. Combination of B1-B2 using one half standard deviation shocks & 121 & 129 & 142 & 142 & 149 & 151 & 136 & 116 \\
\hline B4. One-time 30 percent real depreciation in 2010 & 121 & 145 & 143 & 142 & 149 & 150 & 133 & 100 \\
\hline B5. 10 percent of GDP increase in other debt-creating flows in 2010 & 121 & 144 & 140 & 138 & 142 & 141 & 116 & 78 \\
\hline \multicolumn{9}{|c|}{ Debt Service-to-Revenue Ratio 2/ } \\
\hline Baseline & 15 & 13 & 12 & 12 & 12 & 12 & 10 & 12 \\
\hline \multicolumn{9}{|l|}{ A. Alternative scenarios } \\
\hline A1. Real GDP growth and primary balance are at historical averages & 15 & 13 & 13 & 12 & 13 & 13 & 12 & 17 \\
\hline A2. Primary balance is unchanged from 2009 & 15 & 13 & 12 & 12 & 12 & 12 & 10 & 10 \\
\hline A3. Permanently lower GDP growth $1 /$ & 15 & 13 & 13 & 12 & 12 & 12 & 12 & 17 \\
\hline \multicolumn{9}{|l|}{ B. Bound tests } \\
\hline B1. Real GDP growth is at historical average minus one standard deviations in 2010-2011 & 15 & 14 & 13 & 13 & 13 & 13 & 12 & 17 \\
\hline B2. Primary balance is at historical average minus one standard deviations in $2010-2011$ & 15 & 13 & 13 & 14 & 14 & 13 & 12 & 14 \\
\hline B3. Combination of B1-B2 using one half standard deviation shocks & 15 & 14 & 13 & 13 & 13 & 13 & 12 & 16 \\
\hline B4. One-time 30 percent real depreciation in 2010 & 15 & 15 & 15 & 14 & 14 & 14 & 13 & 16 \\
\hline B5. 10 percent of GDP increase in other debt-creating flows in 2010 & 15 & 13 & 14 & 13 & 13 & 13 & 11 & 13 \\
\hline
\end{tabular}

Sources: Country authorities; and staff estimates and projections

1/ Assumes that real GDP growth is at baseline minus one standard deviation divided by the square root of the length of the projection period.

2/ Revenues are defined inclusive of grants. 
Table 3a.: External Debt Sustainability Framework, Baseline Scenario, 2006-2029 1/ (ln percent of GDP, unless otherwise indicated)

\begin{tabular}{|c|c|c|c|c|c|c|c|c|c|c|c|c|c|c|c|}
\hline & \multicolumn{3}{|c|}{ Actual } & \multirow{2}{*}{$\begin{array}{l}\text { Historical } \\
\text { Average }\end{array}$} & \multirow{2}{*}{$\begin{array}{l}\text { Standard } \\
\text { Deviation }\end{array}$} & \multicolumn{6}{|c|}{ Projections } & \multirow[b]{2}{*}{$2009-2014$} & \multirow[b]{2}{*}{2019} & \multirow[b]{2}{*}{2029} & \multirow[b]{2}{*}{$\begin{array}{c}\begin{array}{c}2015-2029 \\
\text { Average }\end{array} \\
\end{array}$} \\
\hline & 2006 & 2007 & 2008 & & & 2009 & 2010 & 2011 & 2012 & 2013 & 2014 & & & & \\
\hline External debt (nominal) $1 /$ & 38.4 & 25.3 & 22.0 & & & 22.6 & 21.9 & 21.7 & 21.6 & 21.8 & 21.8 & & 16.0 & 9.1 & \\
\hline $\mathrm{o} / \mathrm{w}$ public and publicly guaranteed $(\mathrm{PPG})$ & 28.2 & 16.1 & 14.3 & & & 15.3 & 15.2 & 15.4 & 15.8 & 16.3 & 16.6 & & 12.4 & 7.4 & \\
\hline Change in external debt & -24.6 & -13.0 & -3.3 & & & 0.6 & -0.7 & -0.2 & 0.0 & 0.1 & 0.0 & & -1.0 & -0.5 & \\
\hline Identified net debt-creating flows & -24.3 & -19.0 & -19.3 & & & -7.0 & -4.6 & -3.7 & -3.8 & -3.9 & -3.7 & & -3.1 & -2.1 & \\
\hline Non-interest current account deficit & -13.3 & -13.6 & -13.1 & -6.4 & 6.9 & -4.5 & -3.4 & -2.9 & -3.0 & -3.1 & -3.1 & & -2.9 & -2.1 & -2.7 \\
\hline Deficit in balance of goods and services & -7.7 & -6.1 & -7.6 & -0.7 & 0.0 & -1.1 & -0.1 & 0.2 & 0.1 & 0.0 & 0.3 & & 0.4 & 0.7 & -2.1 \\
\hline Exports & 37.8 & 37.3 & 41.8 & & & 30.1 & 31.5 & 31.8 & 31.3 & 30.9 & 30.4 & & 30.5 & 30.9 & \\
\hline Imports & 30.0 & 31.2 & 34.2 & & & 29.0 & 31.4 & 31.9 & 31.3 & 30.9 & 30.7 & & 30.9 & 31.6 & \\
\hline Net current transfers (negative $=$ inflow) & -7.1 & -9.5 & -7.7 & -6.4 & 1.6 & -5.8 & -5.7 & -5.5 & -5.4 & -5.3 & -5.4 & & -4.4 & -2.9 & -4.0 \\
\hline $\mathrm{o} / \mathrm{w}$ official & -2.6 & -1.7 & -1.2 & & & -0.8 & -1.1 & -1.1 & -1.1 & -1.1 & -1.0 & & -0.8 & -0.3 & \\
\hline Other current account flows (negative $=$ net inflow) & 1.5 & 2.1 & 2.3 & & & 2.4 & 2.4 & 2.4 & 2.4 & 2.2 & 2.0 & & 1.1 & 0.1 & \\
\hline Net FDI (negative $=$ inflow) & -2.4 & -2.1 & -2.2 & -2.9 & 3.8 & -2.9 & -1.4 & -1.2 & -1.4 & -1.3 & -1.2 & & -0.8 & -0.4 & -0.7 \\
\hline Endogenous debt dynamics $2 /$ & -8.5 & -3.3 & -4.0 & & & 0.5 & 0.2 & 0.4 & 0.5 & 0.5 & 0.5 & & 0.6 & 0.3 & \\
\hline Contribution from nominal interest rate & 2.1 & 1.8 & 1.1 & & & 1.1 & 1.1 & 1.2 & 1.4 & 1.4 & 1.4 & & 1.2 & 0.7 & \\
\hline Contribution from real GDP growth & -2.5 & -1.5 & -1.2 & & & -0.7 & -0.8 & -0.8 & -0.8 & -0.8 & -0.8 & & -0.6 & -0.4 & \\
\hline Contribution from price and exchange rate changes & -8.2 & -3.6 & -3.8 & & & 0.1 & & & & & & & & & \\
\hline Residual (3-4) $3 /$ & -0.3 & 5.9 & 15.9 & & & 7.6 & 3.9 & 3.5 & 3.8 & 4.0 & 3.7 & & 2.1 & 1.7 & \\
\hline $\mathrm{o} / \mathrm{w}$ exceptional financing & 0.0 & -0.1 & 0.0 & & & 0.0 & 0.0 & 0.0 & 0.0 & 0.0 & 0.0 & & 0.0 & 0.0 & \\
\hline PV of external debt $4 /$ & $\ldots$ & & 19.4 & & & 21.2 & 22.4 & 23.3 & 24.0 & 25.1 & 26.0 & & 24.8 & 14.7 & \\
\hline In percent of exports & $\ldots$ & $\ldots$ & 46.3 & & & 70.3 & 71.1 & 73.3 & 76.9 & 81.3 & 85.4 & & 81.1 & 47.7 & \\
\hline PV of PPG external debt & ... & ... & 11.6 & & & 13.9 & 15.7 & 17.0 & 18.2 & 19.6 & 20.8 & & 21.2 & 13.0 & \\
\hline In percent of exports & ... & $\ldots$ & 27.8 & & & 46.1 & 49.8 & 53.6 & 58.1 & 63.5 & 68.6 & & 69.5 & 42.2 & \\
\hline In percent of government revenues & & $\ldots$ & 30.9 & & & 44.1 & 47.2 & 50.6 & 53.5 & 59.6 & 63.4 & & 61.7 & 41.9 & \\
\hline Debt service-to-exports ratio (in percent) & 23.5 & 34.1 & 19.0 & & & 8.2 & 7.4 & 7.3 & 7.3 & 6.9 & 6.9 & & 7.6 & 5.5 & \\
\hline PPG debt service-to-exports ratio (in percent) & 16.4 & 28.0 & 16.9 & & & 5.5 & 4.9 & 4.6 & 4.5 & 4.2 & 4.4 & & 5.8 & 4.6 & \\
\hline PPG debt service-to-revenue ratio (in percent) & 19.1 & 31.8 & 18.8 & & & 5.3 & 4.6 & 4.4 & 4.1 & 4.0 & 4.0 & & 5.2 & 4.6 & \\
\hline Total gross financing need (Billions of U.S. dollars) & -0.1 & 0.1 & -0.8 & & & -0.4 & 0.0 & 0.1 & 0.1 & 0.0 & 0.0 & & 0.2 & 0.2 & \\
\hline Non-interest current account deficit that stabilizes debt ratio & 11.3 & -0.5 & -9.8 & & & -5.1 & -2.7 & -2.7 & -2.9 & -3.2 & -3.1 & & -1.9 & -1.6 & \\
\hline \multicolumn{16}{|l|}{ Key macroeconomic assumptions } \\
\hline Real GDP growth (in percent) & 4.8 & 4.6 & 6.1 & 3.8 & 2.3 & 3.3 & 4.0 & 4.0 & 4.0 & 4.0 & 4.0 & 3.9 & 4.0 & 4.0 & 4.0 \\
\hline GDP deflator in US dollar terms (change in percent) & 14.9 & 10.3 & 17.7 & 6.3 & 8.4 & 2.8 & 4.1 & 3.4 & 2.8 & 2.7 & 2.8 & 3.1 & 3.5 & 3.5 & 3.5 \\
\hline Effective interest rate (percent) $5 /$ & 4.1 & 5.4 & 5.3 & 7.9 & 8.8 & 5.5 & 5.1 & 6.1 & 6.7 & 6.7 & 6.7 & 6.1 & 7.6 & 7.7 & 7.6 \\
\hline Growth of exports of G\&S (US dollar terms, in percent) & 32.7 & 13.9 & 40.1 & 18.6 & 14.8 & -23.6 & 13.2 & 8.4 & 5.2 & 5.6 & 5.1 & 2.3 & 7.8 & 7.8 & 7.8 \\
\hline Growth of imports of G\&S (US dollar terms, in percent) & 20.7 & 19.8 & 37.1 & 10.8 & 14.5 & -10.0 & 17.3 & 9.3 & 4.8 & 5.4 & 6.1 & 5.5 & 7.9 & 7.9 & 7.9 \\
\hline Grant element of new public sector borrowing (in percent) & & & & $\ldots$ & & 8.3 & 10.6 & 13.3 & 15.6 & 15.2 & 13.9 & 12.8 & 12.4 & 10.8 & 11.8 \\
\hline Government revenues (excluding grants, in percent of GDP) & 32.5 & 32.7 & 37.7 & & & 31.5 & 33.2 & 33.6 & 34.0 & 32.9 & 32.9 & & 34.4 & 31.1 & 33.4 \\
\hline Aid flows (in Billions of US dollars) $7 /$ & 0.5 & 0.4 & 0.5 & & & 0.3 & 0.4 & 0.5 & 0.5 & 0.6 & 0.6 & & 0.7 & 1.2 & \\
\hline $\mathrm{o} / \mathrm{w}$ Grants & 0.2 & 0.2 & 0.2 & & & 0.2 & 0.2 & 0.2 & 0.2 & 0.3 & 0.3 & & 0.4 & 0.9 & \\
\hline $\mathrm{o} / \mathrm{w}$ Concessional loans & 0.3 & 0.2 & 0.2 & & & 0.1 & 0.2 & 0.3 & 0.3 & 0.3 & 0.3 & & 0.3 & 0.3 & \\
\hline Grant-equivalent financing (in percent of GDP) 8 / & 烈 & $\ldots$ & $\ldots$ & & & 1.3 & 1.5 & 1.6 & 1.6 & 1.6 & 1.6 & & 1.5 & 1.3 & 1.4 \\
\hline Grant-equivalent financing (in percent of external financing) $8 /$ & ... & & $\ldots$ & & & 28.3 & 29.5 & 33.7 & 36.6 & 35.4 & 35.5 & & 42.4 & 56.1 & 46.4 \\
\hline \multicolumn{16}{|l|}{ Memorandum items: } \\
\hline Nominal $\mathrm{C}$ & 11.5 & 13.3 & 16.6 & & & 17.6 & 19.1 & 20.5 & 21.9 & 23.4 & 25.0 & & 36.2 & 75.9 & \\
\hline Nominal dollar GDP growth & 20.4 & 15.3 & 24.9 & & & 6.2 & 8.3 & 7.5 & 6.9 & 6.8 & 6.9 & 7.1 & 7.7 & 7.7 & 7.7 \\
\hline PV of PPG external debt (in Billio & & & 2.0 & & & 2.4 & 3.0 & 3.5 & 4.0 & 4.6 & 5.2 & & 7.7 & 9.9 & \\
\hline (PVt-PVt-1)/GDPt-1 (in percent) & & & & & & 2.6 & 3.1 & 2.6 & 2.4 & 2.8 & 2.6 & 2.7 & 1.2 & 0.2 & 0.9 \\
\hline
\end{tabular}

Sources: Country authorities; and staff estimates and projections.

1/ Includes both public and private sector external deb.

$2 /$ Derived as $[\mathrm{r}-\mathrm{g}-\rho(1+\mathrm{g})](1+\mathrm{g}+\rho+\mathrm{g} \rho)$ times previous period debt ratio, with $\mathrm{r}=$ nominal interest rate; $\mathrm{g}=$ real GDP growth rate, and $\rho=$ growth rate of GDP deflator in U.S. dollar terms.

$3 /$ Includes exceptional financing (i.e., changes in arrears and debt relief); changes in gross foreign assets; and valuation adjustments. For projections also includes contribution from price and exchange rate change.

4/ Assumes that PV of privale sector debt is equivalent to its face value.

6/ Historical averages and standard deviations are generally derived over the past 10 years, subject to data availability.

7/ Defined as grants, concessional loans, and debt relief.

8/ Grant-equivalent financing includes grants provided directly to the government and through new borrowing (difference between the face value and the PV of new debt). 
Table 3b.Bolivia: Sensitivity Analysis for Key Indicators of Public and Publicly Guaranteed External Debt, 2009-2029 (In percent)

\begin{tabular}{|c|c|c|c|c|c|c|c|c|}
\hline & \multicolumn{8}{|c|}{ Projections } \\
\hline & 2009 & 2010 & 2011 & 2012 & 2013 & 2014 & 2019 & 2029 \\
\hline \multicolumn{9}{|c|}{ PV of debt-to GDP ratio } \\
\hline Baseline & 14 & 16 & 17 & 18 & 20 & 21 & 21 & 13 \\
\hline \multicolumn{9}{|l|}{ A. Alternative Scenarios } \\
\hline A1. Key variables at their historical averages in 2009-2029 1/ & 14 & 11 & 7 & 3 & 0 & -3 & -21 & -50 \\
\hline A2. New public sector loans on less favorable terms in 2009-2029 2 & 14 & 17 & 19 & 21 & 23 & 25 & 28 & 22 \\
\hline \multicolumn{9}{|l|}{ B. Bound Tests } \\
\hline B1. Real GDP growth at historical average minus one standard deviation in 2010-2011 & 14 & 16 & 18 & 19 & 20 & 21 & 21 & 12 \\
\hline B2. Export value growth at historical average minus one standard deviation in 2010-2011 3/ & 14 & 18 & 23 & 24 & 25 & 26 & 24 & 13 \\
\hline B3. US dollar GDP deflator at historical average minus one standard deviation in 2010-2011 & 14 & 17 & 19 & 20 & 21 & 23 & 23 & 13 \\
\hline B4. Net non-debt creating flows at historical average minus one standard deviation in 2010-2011 4/ & 14 & 18 & 22 & 23 & 24 & 25 & 23 & 13 \\
\hline B5. Combination of B1-B4 using one-half standard deviation shocks & 14 & 17 & 19 & 20 & 21 & 23 & 22 & 13 \\
\hline B6. One-time 30 percent nominal depreciation relative to the baseline in 20105 / & 14 & 22 & 24 & 25 & 27 & 28 & 28 & 17 \\
\hline \multicolumn{9}{|c|}{ PV of debt-to-exports ratio } \\
\hline Baseline & 46 & 50 & 54 & 58 & 64 & 69 & 69 & 42 \\
\hline \multicolumn{9}{|l|}{ A. Alternative Scenarios } \\
\hline A1. Key variables at their historical averages in 2009-2029 1/ & 46 & 35 & 23 & 11 & 1 & -10 & -70 & -161 \\
\hline A2. New public sector loans on less favorable terms in 2009-2029 2 & 46 & 53 & 59 & 67 & 75 & 82 & 91 & 70 \\
\hline \multicolumn{9}{|l|}{ B. Bound Tests } \\
\hline B1. Real GDP growth at historical average minus one standard deviation in 2010-2011 & 46 & 49 & 53 & 57 & 62 & 66 & 66 & 38 \\
\hline B2. Export value growth at historical average minus one standard deviation in 2010-2011 3/ & 46 & 62 & 81 & 86 & 91 & 96 & 89 & 47 \\
\hline B3. US dollar GDP deflator at historical average minus one standard deviation in 2010-2011 & 46 & 49 & 53 & 57 & 62 & 66 & 66 & 38 \\
\hline B4. Net non-debt creating flows at historical average minus one standard deviation in 2010-2011 4/ & 46 & 59 & 70 & 73 & 78 & 82 & 77 & 41 \\
\hline B5. Combination of B1-B4 using one-half standard deviation shocks & 46 & 54 & 56 & 60 & 65 & 69 & 68 & 39 \\
\hline B6. One-time 30 percent nominal depreciation relative to the baseline in 20105 / & 46 & 49 & 53 & 57 & 62 & 66 & 66 & 38 \\
\hline \multicolumn{9}{|c|}{ PV of debt-to-revenue ratio } \\
\hline Baseline & 44 & 47 & 51 & 54 & 60 & 63 & 62 & 42 \\
\hline \multicolumn{9}{|l|}{ A. Alternative Scenarios } \\
\hline A1. Key variables at their historical averages in 2009-2029 1/ & 44 & 33 & 21 & 10 & 1 & -9 & -62 & -160 \\
\hline A2. New public sector loans on less favorable terms in 2009-2029 2 & 44 & 50 & 56 & 61 & 70 & 76 & 81 & 69 \\
\hline \multicolumn{9}{|l|}{ B. Bound Tests } \\
\hline B1. Real GDP growth at historical average minus one standard deviation in 2010-2011 & 44 & 48 & 52 & 55 & 61 & 64 & 61 & 40 \\
\hline B2. Export value growth at historical average minus one standard deviation in 2010-2011 3/ & 44 & 54 & 68 & 69 & 75 & 78 & 69 & 41 \\
\hline B3. US dollar GDP deflator at historical average minus one standard deviation in 2010-2011 & 44 & 50 & 56 & 59 & 65 & 69 & 66 & 43 \\
\hline B4. Net non-debt creating flows at historical average minus one standard deviation in 2010-2011 4/ & 44 & 56 & 66 & 68 & 73 & 76 & 68 & 41 \\
\hline B5. Combination of B1-B4 using one-half standard deviation shocks & 44 & 52 & 57 & 59 & 65 & 69 & 64 & 41 \\
\hline B6. One-time 30 percent nominal depreciation relative to the baseline in $20105 /$ & 44 & 66 & 70 & 74 & 82 & 86 & 82 & 54 \\
\hline
\end{tabular}

Baseline

A. Alternative Scenarios

A1. Key variables at their historical averages in 2009-2029 1/

A2. New public sector loans on less favorable terms in 2009-2029 2

B. Bound Tests

B1. Real GDP growth at historical average minus one standard deviation in 2010-2011

B2. Export value growth at historical average minus one standard deviation in 2010-2011 3 /

B3. US dollar GDP deflator at historical average minus one standard deviation in 2010-2011

B4. Net non-debt creating flows at historical average minus one standard deviation in 2010-2011 4/

B5. Combination of B1-B4 using one-half standard deviation shocks

B6. One-time 30 percent nominal depreciation relative to the baseline in 20105 /

Debt service-to-exports ratio . 
Figure 1.Bolivia: Indicators of Public Debt Under Alternative Scenarios, 2009-2029 1/
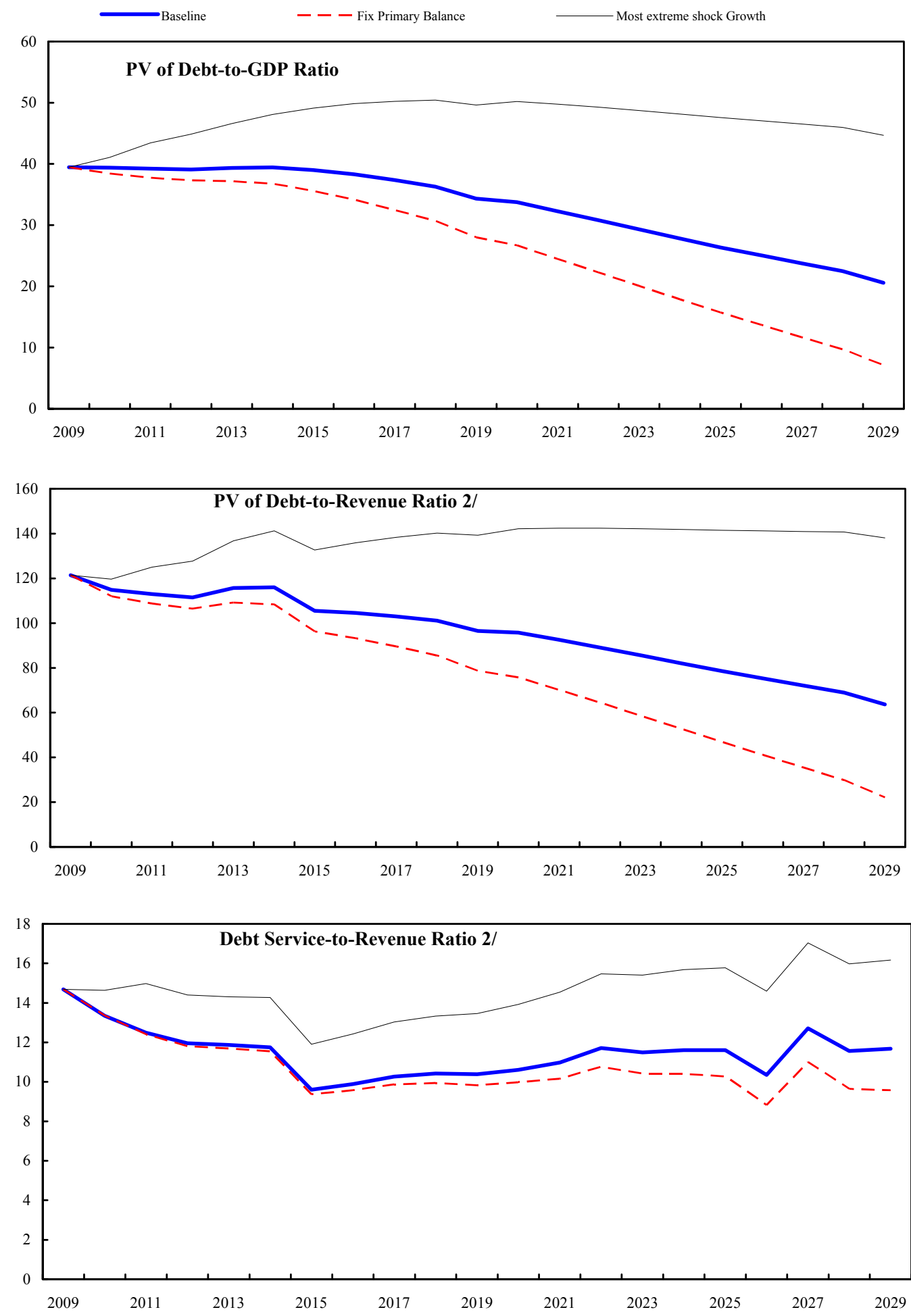

Sources: Country authorities; and staff estimates and projections.

$1 /$ The most extreme stress test is the test that yields the highest ratio in 2019.

$2 /$ Revenues are defined inclusive of grants. 
Figure 2. Bolivia: Indicators of Public and Publicly Guaranteed External Debt under Alternatives Scenarios, 2009-2029 1/
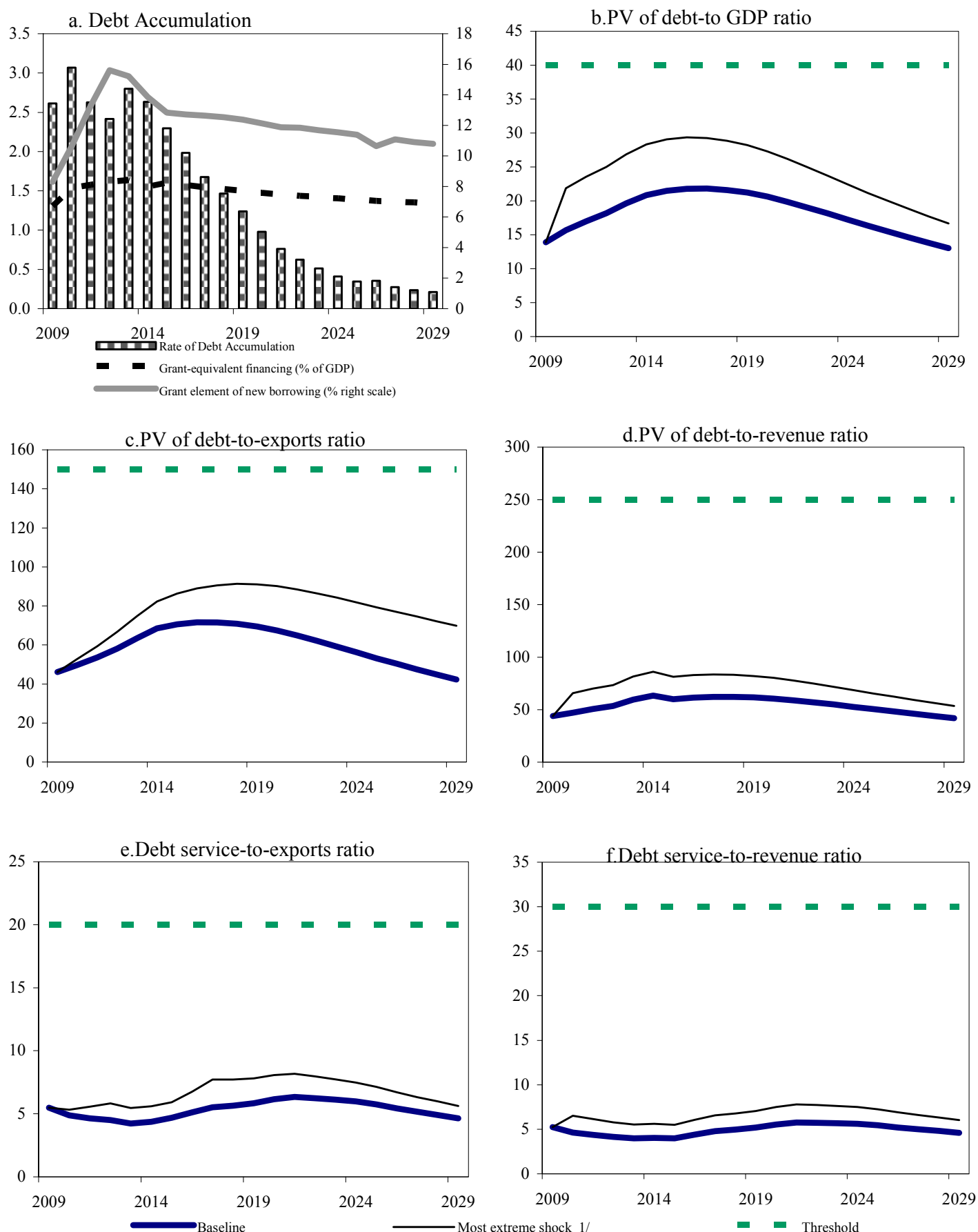

Sources: Country authorities; and staff estimates and projections.

1/ The most extreme stress test is the test that yields the highest ratio in 2019. In figure b. it corresponds to a One-time depreciation shock; in c. to a Terms shock; in d. to a One-time depreciation shock; in e. to a Exports shock and in figure f. to a One-time depreciation shock 


\title{
INTERNATIONAL MONETARY FUND
}

BOLIVIA

\section{Staff Report for the 2009 Article IV Consultation-Informational Annex}

\author{
Prepared by the Western Hemisphere Department
}

December 23, 2009

Contents

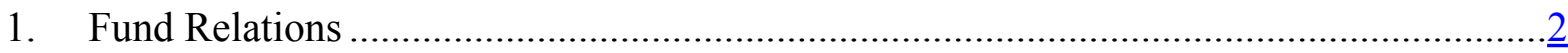

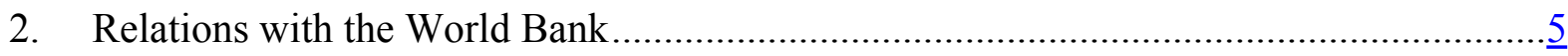

3. Relations with the Inter-American Development Bank ………………………................

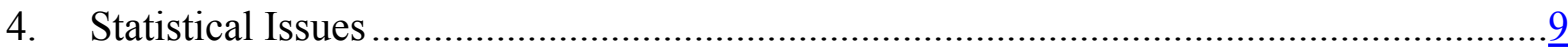




\section{APPENDIX 1. BOLIVIA-FUND RELATIONS}

(As of November 30, 2009)

I. Membership Status: Joined December 27, 1945; accepted its obligations under Article VIII on June 5, 1967. The exchange system is free of restrictions on current international payments and transfers.

II. General Resources Account:

Quota

Fund holdings of currency

Reserve position in Fund

III. SDR Department:

Net cumulative allocation

Holdings
SDR Million

171.50

162.64

8.87

\section{SDR Million}

164.13

164.91
Percent of Quota

100.00

94.83

5.17

Percent of Allocation

100.00

100.47

IV. Outstanding Purchases and Loans: None

V. Financial Arrangements:

$\begin{array}{lrrrr}\text { Type } & \begin{array}{r}\text { Approval } \\ \text { date }\end{array} & \begin{array}{r}\text { Expiration } \\ \text { date }\end{array} & \begin{array}{r}\text { Amount approved } \\ \text { (SDR million) }\end{array} & \begin{array}{r}\text { Amount drawn } \\ \text { (SDR million) }\end{array} \\ \text { Stand-By } & 4 / 02 / 03 & 3 / 31 / 06 & 145.78 & 111.50 \\ \text { PRGF } & 9 / 18 / 98 & 6 / 07 / 02 & 100.96 & 63.86 \\ \text { PRGF } & 12 / 19 / 94 & 9 / 09 / 98 & 100.96 & 100.96\end{array}$

VI. Projected Obligations to the Fund: (SDR million; based on existing use of resources and present holdings of SDRs):

\begin{tabular}{lcccc}
\hline & \multicolumn{4}{c}{ Forthcoming } \\
\cline { 2 - 5 } & $\mathbf{2 0 0 9}$ & $\mathbf{2 0 1 0}$ & $\mathbf{2 0 1 1}$ & $\mathbf{2 0 1 2}$ \\
\hline Principal & & & & \\
Charges/Interest & 0.01 & 0.01 & 0.01 & 0.01 \\
Total & $\mathbf{0 . 0 0}$ & $\mathbf{0 . 0 0}$ & $\mathbf{0 . 0 0}$ & $\mathbf{0 . 0 0}$ \\
\hline
\end{tabular}




\section{Implementation of HIPC Initiative:}

\begin{tabular}{|c|c|c|c|c|}
\hline & & $\begin{array}{r}\text { Original } \\
\text { Framework }\end{array}$ & $\begin{array}{r}\text { Enhanced } \\
\text { Framework }\end{array}$ & Total \\
\hline \multicolumn{5}{|c|}{ I. Commitment of HIPC assistance } \\
\hline & Decision point date & Sep 1997 & Feb 2000 & \\
\hline \multicolumn{5}{|c|}{ Assistance committed } \\
\hline & by all creditors (US\$ Million) $)^{1 /}$ & 448.00 & 854.00 & \\
\hline & Of which: IMF assistance (US\$ million) & 29.00 & 55.32 & \\
\hline & (SDR equivalent in millions) & 21.25 & 41.14 & \\
\hline & Completion point date & Sep 1998 & Jun 2001 & \\
\hline \multicolumn{5}{|c|}{ II. Disbursement of IMF assistance (SDR Million) } \\
\hline & Assistance disbursed to the member & 21.25 & 41.14 & 62.39 \\
\hline & Interim assistance & $\ldots$ & ... & ... \\
\hline & Completion point balance & 21.25 & 41.14 & 62.39 \\
\hline & Additional disbursement of interest income $e^{2 /}$ & $\ldots$ & 3.09 & 3.09 \\
\hline & Total disbursements & 21.25 & 44.23 & 65.48 \\
\hline \multicolumn{5}{|c|}{ III. Implementation of MDRI Assistance } \\
\hline & I Total Debt Relief (SDR Million) $)^{3 /}$ & & & 160.93 \\
\hline & Of Which: MDRI & & & 154.82 \\
\hline & HIPC & & & 6.11 \\
\hline & II. Debt Relief by Facility (SDR Million) & & & \\
\hline
\end{tabular}

${ }^{1 /}$ Assistance committed under the original framework is expressed in net present value (NPV) terms at the completion point, and assistance committed under the enhanced framework is expressed in NPV terms at the decision point. Hence these two amounts can not be added.

${ }^{2 /}$ Under the enhanced framework, an additional disbursement is made at the completion point corresponding to interest income earned on the amount committed at the decision point but not disbursed during the interim period.

${ }^{3 /}$ The Multilateral Debt Relief Initiative (MDRI) provides 100 percent debt relief to eligible member countries that are qualified for the assistance. The debt relief covers the full stock of debt owed to the Fund as of end2004 which remains outstanding at the time the member qualifies for such debt relief. The MDRI is financed by bilateral contributions and the Fund's own resources, as well as the resources already disbursed to the member under the HIPC Initiative (see Section VII above).

Eligible Debt

\begin{tabular}{lrrr}
\hline Delivery Date & GRA & PRGF & Total \\
\hline January 2006 & 6.70 & 71.15 & 77.85 \\
January 2006 & 83.08 & N/A & 83.08 \\
\hline
\end{tabular}

VIII. Safeguards Assessment. Under the Fund's safeguards assessment policy, the Central Bank of Bolivia (CBB) was subject to an assessment with respect to the April 2, 2003 Standby Arrangement (SBA). A safeguards assessment was completed on June 27, 2003, and while no systemic risks with the CBB's safeguards were identified, uncertainties were 
expressed about the de facto lack of operational independence and program monetary data. An update assessment was completed on September 27, 2004 in conjunction with an augmentation of the SBA. This assessment confirmed that measures had been implemented to address all previously identified vulnerabilities, except for those requiring a change in the central bank law. Currently, CBB is not subject to the policy.

IX. Exchange Arrangement. The Bolivian currency is the Boliviano and the exchange rate regime is a stabilized arrangement against the U.S. dollar. ${ }^{1}$ However, the authorities indicate that the de jure regime is a crawling peg, and that the exchange rate will be adjusted from time to time in light of the evaluation of Bolivia's real effective exchange rate with respect to key trading partners. The official selling rate has been unchanged at US\$7.07 per U.S. dollar since October 2008.

X. Article IV Consultation. The last Article IV consultation was completed by the Executive Board on January 14, 2009 (IMF Country Report No. 09/27). Bolivia is on a standard 12-month consultation cycle.

\section{Technical Assistance, 2005-09}

\begin{tabular}{lll}
\hline Department & \multicolumn{1}{c}{ Purpose } & \multicolumn{1}{c}{ Date } \\
\hline FAD & Public expenditure management: the budget process & April 2005 \\
FAD & Tax policy & August 2005 \\
FAD & Decentralization and public expenditure management & October 2005 \\
STA & Monetary statistics & March 2006 \\
FAD & Public finance information system & December 2006 \\
STA & ROSC Data Module & January 2007 \\
MCM & Inflation targeting & June 2007 \\
STA & National Accounts & September 2007 \\
FAD & Tax policy & March 2008 \\
STA & National Accounts & August 2008 \\
FAD & Treasury Operations, Cash and Debt Management & November 2008 \\
& Expenditure Policy (Fiscal and distributional implications of & \\
FAD & petroleum product pricing) & March 2009 \\
& Public Financial Management (Intergovernmental fiscal & \\
FAD & relations) & July/August 2009 \\
FAD & Tax Policy (Tax reform and taxation of natural resources) & July/August 2009 \\
STA & National Accounts & October 2009 \\
\hline
\end{tabular}

XII. Resident Representative. Mr. Luis Breuer took over the post of IMF resident representative in June 2009.

\footnotetext{
${ }^{1}$ See Habermeier, et al., Revised System for the Classification of Exchange Rate Arrangements, WP/09/211.
} 


\section{APPENDIX 2. BOLIVIA: RELATIONS WITH THE WORLD BANK ${ }^{1}$}

\section{The Interim Strategy Note (ISN) that defines the World Bank Group's support} to Bolivia for FY10-11 was discussed and approved by the Board on June 2, 2009. The ISN has a total envelope of US\$137 million of IDA resources. The lending program amounts to US\$90 million in predefined operations while US\$47 million has been left available for flexible use, to respond to the unforeseen needs, support the Government's efforts to stem the impact of the global crisis, and to reduce extreme poverty. World Bank's support to Bolivia includes financing and analytical and advisory activities in four strategic areas requested by the Government that consolidate the progress accomplished with the previous strategy: (i) productive development and support to production; (ii) sustainable development; (iii) human development; and (iv) governance and support to public sector.

\section{The World Bank's portfolio in Bolivia comprises 11 investment projects for a} total amount of US\$302.8 million of which US\$190.6 remain undisbursed. The portfolio has been built in recent years with most of the projects (8) approved under the previous ISN, which covered FY07 and FY08, and have therefore just started implementation. In addition, in April 2009, the Board approved a US\$30 million Additional Financing for the ongoing Rural Alliances Project. The portfolio is entirely financed with IDA resources and includes the following projects:

\begin{tabular}{lccr}
\hline \multicolumn{1}{c}{ Project } & $\begin{array}{c}\text { Commitment } \\
\text { (US\$ million) }\end{array}$ & $\begin{array}{c}\text { Disbursed } \\
\text { (US\$ million) }\end{array}$ & Closing Date \\
\hline Decentralized Infrastructure for Rural Transformation & 20.0 & 7.5 & November 2009 \\
Road rehabilitation and Maintenance & 77.0 & 61.6 & December 2009 \\
Urban Infrastructure & 30.0 & 18.3 & November 2010 \\
Secondary Education Transformation & 10.0 & 2.2 & December 2010 \\
Land for Agricultural Development & 15.0 & 1.3 & June 2012 \\
Emergency Recovery and Disaster Management & 16.9 & 2.8 & June 2012 \\
Participatory Rural Investment II & 20.0 & 1.8 & March 2013 \\
Lake Titicaca Local Sustainable Development & 20.0 & 0.7 & June 2013 \\
Investing in Children and Youth & 17.0 & 0.6 & December 2013 \\
Expanding Access to Reduce Health Inequalities & 18.5 & 0.0 & January 2014 \\
Rural Alliances & 58.4 & 15.4 & March 2014 \\
\hline TOTAL & $\mathbf{3 0 2 . 8}$ & $\mathbf{1 1 2 . 2}$ & \\
\hline
\end{tabular}

3. The ISN's new lending program includes the following pipeline of investment operations: Monitoring and Evaluation of MDGs (slipped from the previous ISN), Urban Alliances (former Productivity and Job Creation, slipped from the previous ISN), Innovation and Agricultural Services, Rural Roads, and Community Driven Development to Support the Eradication of Poverty. Moreover, the Government is considering a request for additional financing in FY10 for some projects currently under implementation: Urban Infrastructure

\footnotetext{
${ }^{1}$ Prepared by World Bank staff.
} 
for the Poor, Secondary Education Transformation in the Municipality of La Paz, and the Social Protection Project.

4. The Government is considering access to non-concessional funding in addition to IDA resources. Taking into account its GNI per capita, Bolivia has been a blend country since FY2002. However, the country has only had access to IDA resources. Considering its anticipated financing needs in 2010, the Government is seeking access to IBRD funding in addition to its IDA allocation.

5. In addition to the investment portfolio, the World Bank program includes Trust Funds and Global Programs. The Bank is currently managing three grants amounting to US\$5.5 million, which support institutional strengthening and project execution. These include: Global Partnership on Output Based Aid (US\$5.2 million), Strengthening of the Deputies Chamber Finance Commission (US\$0.2 million), and Strengthening Donor Aid Coordination (\$0.1 million). In addition a South-South Trust Fund (US\$0.1 million) has been approved to support the Government in the design of its program to eradicate extreme poverty.

6. In terms of analytical and advisory activities, the World Bank is carrying out a comprehensive set of tasks in areas requested by the Government. Current Economic and Sector Work (ESW) and Non-Lending Technical Assistance (NLTA) include the following:

- $\quad$ Public Expenditure and Financial Assessment - PEFA

- $\quad$ Rising Food Prices in Bolivia (ESW)

- $\quad$ Municipal Services and Finances (ESW)

- $\quad$ Agricultural Public Expenditure Review (ESW)

- $\quad$ Economic and Social Impact of Climate Change (ESW)

- Social Protection Phases III and IV (Non-lending Technical Assistance)

- $\quad$ Education (NLTA)

- $\quad$ Strengthening the Public Investment System (NLTA)

- $\quad$ Multidimensional Poverty (NLTA)

- $\quad$ Natural Gas (NLTA)

- $\quad$ Private Sector Development Dialogue (NLTA) 


\section{APPENDIX 3. BOLIVIA: RELATIONS WITH THE INTER-AMERICAN DEVELOPMENT BANK ${ }^{1}$}

1. As of November 30, 2009, the Inter-American Development Bank (IDB) had approved loans to Bolivia amounting to US\$4.31 billion, with disbursements totaling US $\$ 3.72$ billion. Bolivia's outstanding debt to the IDB was approximately US $\$ 562$ millions with undisbursed approved funds for US $\$ 587.8$ millions. Net cash flows to the country are expected to be positive to the country for the first time since 2005, a trend expected to continue in the base scenario to 2015. At the end of 2007, the IDB unilaterally joined the IMF-WB MDRI initiative, by writing off a total of US\$741.1 million in principal payments and US\$307.3 millions of future interest payments, generating an estimated annual fiscal space of more than US\$18 millions on average.

\section{The IDB has implemented a new criterion of allocation of concessional lending.}

Consistent with the application of the Debt Sustainability Framework and after the last round of debt relief, new IDB lending to Bolivia will be following newly adopted operational guidelines for concessional funds under the Fund of Special Operations performance-based allocation system. Parallel lending operations, modality that features differential combination between ordinary and concessional funding, will be enacted as the preferred lending instrument up to 2015. Bolivia will be allocated 30 percent of concessional element under IDB's blended financial conditions. During the 2009-2010, attending an increasing demand of international finance flows from the region due to eroded global conditions; the IDB increased temporarily the availability of funds for its concessional window, with Bolivia enjoying an annual allocation of US\$191 millions for 2009 and US\$200 millions for 2010.

\section{Under the 2008-2010 Bank's country strategy with Bolivia, the government and} the IDB have agreed on keeping sustainable poverty reduction as main objective of their strategic engagement. In pursuit of this objective, the Bank has aligned its actions with those contained by Bolivia's National Development Plan in order to achieve a grater degree of coordination among international cooperation entities acting in Bolivia, while better targeting priority areas in the poverty reduction action plan. Four main strategic areas are proposed under the new strategy: (i) productivity, competitiveness and productive infrastructure, to promote economic growth consistent with poverty reduction targets; (ii) water, sanitation and social development to target high-poverty municipalities; (iii) building opportunities for the majority and development with identity to enhance the participation of the bottom tiers of the income distribution; and (iv) institutional strengthening of the state at both national and sub-national levels, to achieve higher efficiency of the public sector while promoting the decentralization process.

\footnotetext{
${ }^{1}$ Prepared by IDB staff.
} 
4. As of November 30, 2009 the portfolio of executing sovereign-guaranteed operations in Bolivia consists of 33 loans, totaling US\$1.03 billions, o which 43 percent has already been disbursed. The current executing portfolio supports mostly water and sanitation, health, infrastructure and productivity interventions. The undisbursed sovereign portfolio is concentrated (53 percent) in the transportation sector. The non-sovereignguaranteed executing portfolio consists of 3 loans totaling US\$114 millions, of which 86.8 percent has already been disbursed. The Bank's 2009 operative program contains a portfolio of sovereign guaranteed operations of 6 loans for a total amount of US\$191 millions for the year, concentrated in water, housing and agricultural productivity sectors. An additional of 9 loans for US\$200 millions has been identified and are already in the Bank's lending pipeline for the 2010 cycle. 


\section{APPENDIX 4. BOLIVIA-STATISTICAL ISSUES APPENDIX}

As of November 4, 2009

\section{Assessment of Data Adequacy for Surveillance}

General: Data provision has some shortcomings, but is broadly adequate for surveillance.

National Accounts: The National Institute of Statistics (INE) has begun a thorough revision of the national accounts statistics, including the updating of the base year (currently dating from 1990) and an intensified implementation of the System of National Accounts 1993 (SNA 1993).

Labor market. The quality of the household and employment surveys has deteriorated in the last few years, due mainly to financial constraints. The quarterly employment survey was discontinued in 2003, leading to a lack of quarterly information on unemployment, employment and wages.

Prices statistics: Industrial producer price indices and external trade unit values are compiled by INE, but are in need of revision as regards concepts and definitions consistent with $S N A 1993$, as well as treatment of seasonal products, missing items, quality changes, and introduction of new products.

Government finance statistics: Annual data on the operations of the consolidated central government do not cover all operations of decentralized agencies and operations channeled through special funds. The ongoing implementation of a comprehensive financial management system, with funding from the IADB/WB, will help ensure proper monitoring of public sector financial operations including subnational fiscal operations, debt and social spending. It will also be important to improve on the reporting of the operations and debt of public enterprises.

Balance of payments: Despite recent improvements in the coverage of private capital flows and positions, as noted by the January 2007 Data ROSC mission, the coverage of certain services and financial transactions in the balance of payments needs to be expanded.

\section{Data Standards and Quality}

Bolivia has participated in the General Data Dissemination System (GDDS) since November 2002. Data ROSC published on August 13, 2007. 
BOLIVIA: INDICATORS REQUIRED FOR SURVEILLANCE

(As of November 30, 2009)

\begin{tabular}{|c|c|c|c|c|c|c|c|}
\hline & & & & & & & Items \\
\hline & $\begin{array}{r}\text { Date of } \\
\text { latest } \\
\text { observation }\end{array}$ & $\begin{array}{r}\text { Date } \\
\text { received }\end{array}$ & $\begin{array}{c}\text { Frequency } \\
\text { of } \\
\text { Data }^{1}\end{array}$ & $\begin{array}{l}\text { Frequency } \\
\text { of } \\
\text { Reporting }^{1}\end{array}$ & $\begin{array}{c}\text { Frequency } \\
\text { of } \\
\text { publication }^{1}\end{array}$ & $\begin{array}{c}\text { Data Quality- } \\
\text { Methodological } \\
\text { soundness }^{10}\end{array}$ & $\begin{array}{l}\text { Data Quality-Accuracy } \\
\text { and reliability } \\
{ }^{11}\end{array}$ \\
\hline Exchange Rates & Daily & Daily & $\mathrm{D}$ & $\mathrm{D}$ & $\mathrm{D}$ & & \\
\hline $\begin{array}{l}\text { International Reserve Assets and Reserve Liabilities of the Monetary } \\
\text { Authorities }^{2}\end{array}$ & Daily & Daily & $\mathrm{D}$ & $\mathrm{D}$ & $\mathrm{D}$ & & \\
\hline Reserve/Base Money & Sep. 2009 & Oct. 2009 & $\mathrm{M}$ & $\mathrm{M}$ & M & $\mathrm{O}, \mathrm{LO}, \mathrm{LO}, \mathrm{O}$ & $\mathrm{O}, \mathrm{O}, \mathrm{O}, \mathrm{O}, \mathrm{O}$ \\
\hline Broad Money & Sep. 2009 & Oct. 2009 & M & $\mathrm{M}$ & M & & \\
\hline Central Bank Balance Sheet & Sep. 2009 & Oct. 2009 & $\mathrm{M}$ & $\mathrm{M}$ & $\mathrm{M}$ & & \\
\hline Consolidated Balance Sheet of the Banking System & Sep. 2009 & Oct. 2009 & M & M & M & & \\
\hline Interest Rates $^{3}$ & Oct. 2009 & Nov. 2009 & W & W & M & & \\
\hline Consumer Price Index & Oct. 2009 & Nov. 2009 & M & $\mathrm{M}$ & M & $\mathrm{LO}, \mathrm{O}, \mathrm{LO}, \mathrm{O}$ & $\mathrm{O}, \mathrm{LO}, \mathrm{LNO}, \mathrm{O}, \mathrm{LO}$ \\
\hline $\begin{array}{l}\text { Revenue, Expenditure, Balance and Composition of Financing }{ }^{4}-\text { General } \\
\text { Government }{ }^{5}\end{array}$ & Jul. 2009 & Oct. 2009 & M & M & M & LO, LO, LNO, LO & $\mathrm{LO}, \mathrm{O}, \mathrm{O}, \mathrm{O}, \mathrm{LO}$ \\
\hline $\begin{array}{l}\text { Revenue, Expenditure, Balance and Composition of Financing }{ }^{4}-\text { Central } \\
\text { Government }^{6}\end{array}$ & $\mathrm{n} / \mathrm{a}$ & $\mathrm{n} / \mathrm{a}$ & $\mathrm{n} / \mathrm{a}$ & $\mathrm{n} / \mathrm{a}$ & $\mathrm{n} / \mathrm{a}$ & & \\
\hline Stock of Central Government and Central Government-Guaranteed Debt ${ }^{7}$ & Jun. 2009 & Nov. 2009 & $\mathrm{M}$ & $\mathrm{M}$ & $\mathrm{M}$ & & \\
\hline External Current Account Balance & Q2 2009 & Sep. 2009 & Q & Q & Q & $\mathrm{O}, \mathrm{LO}, \mathrm{LO}, \mathrm{LO}$ & $\mathrm{LO}, \mathrm{O}, \mathrm{LO}, \mathrm{O}, \mathrm{LO}$ \\
\hline Exports and Imports of Goods and Services $^{8}$ & Q2 2009 & Sep. 2009 & Q & Q & Q & & \\
\hline GDP/GNP & Q2 2009 & Sep 2009 & $\mathrm{Q}$ & Q & Q & LO, LO, LO, O & LNO, LO, LNO, O, LO \\
\hline Gross External Debt & Oct. 2009 & Nov. 2009 & $\mathrm{M}$ & $\mathrm{M}$ & $\mathrm{M}$ & & \\
\hline International Investment Position $^{9}$ & Q2 2009 & Sep. 2009 & Q & Q & Q & & \\
\hline
\end{tabular}

Daily (D), Weekly (W), Monthly (M), Quarterly (Q), Annually (A); Irregular (I); Not Available (NA).

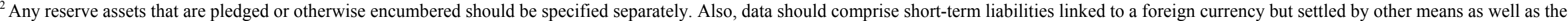
notional values of financial derivatives to pay and to receive foreign currency, including those linked to a foreign currency but settled by other means.

3 Both market-based and officially-determined, including discount rates, money market rates, rates on treasury bills, notes and bonds.

${ }^{4}$ Foreign, domestic bank, and domestic nonbank financing.

${ }^{5}$ The general government consists of the central government (budgetary funds, extra budgetary funds, and social security funds) and state and local governments.

${ }^{6}$ Bolivia does not compile central government fiscal data.

${ }^{7}$ Guaranteed non-financial public sector debt. Including currency and maturity composition.

${ }^{8}$ Monthly frequency for goods only.

${ }^{9}$ Includes external gross financial asset and liability positions vis-à-vis nonresidents.

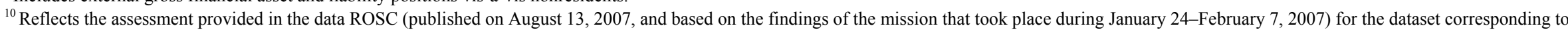

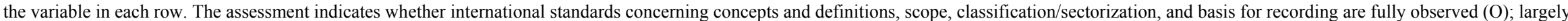
observed (LO); largely not observed (LNO); not observed (NO); and not available (NA).

${ }^{11}$ Same as footnote 10, except referring to international standards concerning (respectively) source data, assessment of source data, statistical techniques, assessment and validation of intermediate data and statistical outputs, and revision studies.

\section{CInternational Monetary Fund. Not for Redistribution}




\section{Statement by the Staff Representative on Bolivia \\ January 15, 2010}

1. This statement provides additional information that has become available since the issuance of the staff report. It does not alter the thrust of the staff appraisal.

2. The 12-month inflation rate declined further to 0.26 percent in December, the lowest rate in the last 20 years. The government has announced an increase in the minimum wage of 5 percent in 2010, to the equivalent of US\$97 dollars a month, covering all public and private sector employees.

3. Net International Reserves reached US\$ 8.6 billion by end-2009, equivalent to more than 80 percent of broad money and over 20 months of imports of goods and services.

4. The 2010 Budget Law was enacted on December 31, 2009. The spending envelope therein is consistent with the fiscal projections presented in the staff report, and the law includes useful provisions to improve cash-management, oversight of multiyear investment projects, and information on budget execution. The law also establishes a new central bank facility for financing to public enterprises, with a limit of US\$1 billion (about 5.2 percent of GDP). ${ }^{1}$ The new facility is earmarked for investment projects that would address food and energy security concerns. As such projects have not yet been finalized, the budget does not contain specific spending allocations for this purpose.

\footnotetext{
${ }^{1}$ This facility is in addition to the one authorized for the same amount in the 2009 Budget law to finance investments by the state-owned oil company ( YPFB), as reported in paragraph 12 of the Staff Report.
} 


\section{INTERNATIONAL MONETARY FUND}

Public Information Notice

Public Information Notice (PIN) No. 10/09 FOR IMMEDIATE RELEASE January 21,2010
International Monetary Fund $70019^{\text {th }}$ Street, NW

Washington, D. C. 20431 USA

\section{IMF Executive Board Concludes 2009 Article IV Consultation with Bolivia}

On January 15, 2010, the Executive Board of the International Monetary Fund (IMF) concluded the 2009 Article IV consultation with Bolivia. ${ }^{1}$

\section{Background}

In recent years, Bolivia benefited from a sharp improvement in terms of trade. Increased export volumes of gas and mining and the concurrent boom in commodities prices led to a 230 percent increase in export receipts between 2005 and 2008. Real GDP growth, which averaged 3.4 percent annually during 1996-2005, increased to an average of 5.2 percent in 2006-08, peaking at 6.1 percent in 2008 . The external and fiscal positions strengthened sharply during the boom years.

Larger export receipts, coupled with higher taxation of the hydrocarbon sector and moderate rates of increase in government spending, led to substantial external current account and fiscal surpluses, which averaged 11.8 percent of GDP and 3.8 percent of GDP respectively in 200608. These surpluses contributed to the build-up of a comfortable reserves buffer, which-added to the debt relief obtained under MDRI-turned Bolivia into a net external creditor in 2008.

\footnotetext{
${ }^{1}$ Under Article IV of the IMF's Articles of Agreement, the IMF holds bilateral discussions with members, usually every year. A staff team visits the country, collects economic and financial information, and discusses with officials the country's economic developments and policies. On return to headquarters, the staff prepares a report, which forms the basis for discussion by the Executive Board. At the conclusion of the discussion, the Managing Director, as Chairman of the Board, summarizes the views of Executive Directors, and this summary is transmitted to the country's authorities.
} 
Gross public sector debt declined to less than 40 percent of GDP by 2008 and net public sector debt to only 20 percent of GDP, thanks to the accumulation of substantial deposits at the central bank. However, despite the highly favorable trends, private investment remained subdued, while the authorities have focused on expanding the social safety net and improving infrastructure.

Real output growth is projected to slow to $3 \frac{11}{4}$ percent in 2009 as a result of lower export volumes, mostly due to reduced gas demand from Brazil, and weakened domestic absorption due to the negative terms of trade shock and falling remittances. Lower food prices and a slowdown in domestic demand have contributed to a sharp decline in the 12-month inflation rate, which declined to 0.3 percent by end-2009. Lower commodity exports and remittances have resulted in a sharp narrowing of the external current account surplus to about $3 \frac{1}{2}$ percent of GDP, compared with 12 percent of GDP in 2008.

The combined fiscal surplus is expected to narrow by 4 percentage points of GDP to an almost balanced position in 2009, largely due to lower hydrocarbon and tax revenue (by 5 percentage points of GDP). In parallel, the central bank reduced open market operations while letting the short-term policy interest rates decline to almost zero, in the context of a decline in foreigncurrency inflows that had sharply slowed money creation. This is being transmitted gradually into banks' deposit and loan rates, which remain at record low levels (1.3 percent and 8.3 percent respectively). With regard to exchange rate policy, since October 2008 the central bank has effectively pegged the Boliviano to the U.S. dollar, following a period of negative crawl (i.e., gradual appreciation) that started in mid-2005.

The financial system has been barely affected by the global crisis owing to limited integration with international capital markets. With negligible foreign credit lines in banks' balance sheets and lack of exposure to impaired foreign assets, banks have remained liquid, profitable, and well capitalized. The strengthening of economic fundamentals and measures to induce voluntary Bolivianization of financial assets have led to a significant decline in dollarization. Nonetheless, the authorities have increased marginal reserve requirements on dollar deposits to build up a higher foreign-currency liquidity cushion for banks, and also have tightened provisioning requirements, including through higher provisioning for dollar-denominated loans.

Real GDP growth is expected to pick up to 4 percent in 2010, reflecting mainly a recovery of hydrocarbon exports and public investment, and still favorable terms-of-trade, with inflation projected to rise to about 4 percent. The external current account surplus is expected to narrow moderately to $2 \frac{1}{2}$ percent of GDP, as a result of increased domestic absorption, while the overall balance of payments is projected to remain positive, leading to a further accumulation of international reserves. 


\section{Executive Board Assessment}

Executive Directors commended the Bolivian authorities for their continued sound macroeconomic management and effective policy response to mitigate the impact of the global crisis. Growth has been among the highest in Latin America and inflation has declined sharply in a context of financial stability. Fiscal policy has focused on protecting social and infrastructure spending; the temporary stabilization of the Boliviano against the US dollar has provided a nominal anchor, protecting the substantial de-dollarization already achieved; and lower interest rates have supported credit demand. Looking forward, Directors concurred that the key challenges are to maintain long-term fiscal sustainability through prudent management of the country's natural resource wealth and to further reduce the high poverty rate by boosting growth through structural reforms and increased investment.

Directors generally supported a gradual tightening of monetary conditions as the economy rebounds. Mopping up the abundant liquidity in the banking sector would prevent excessive credit creation, foreign-exchange pressures, or a pick-up in inflation. Directors noted the staff's assessment of no significant evidence of exchange-rate misalignment. They welcomed the authorities' readiness to revise the rate of crawl of the exchange rate when called for by fundamentals and market conditions. Over the medium term, most Directors encouraged the authorities to set the stage for greater exchange rate flexibility, once low dollarization is entrenched and domestic financial markets have gained greater depth. A few Directors however saw no need to move in this direction, noting that the current regime has served the country well. To strengthen the independence of monetary policy, Directors considered that central bank financing of the government or public corporations should be avoided.

Directors welcomed the authorities' sound fiscal policy, with public debt expected to continue to decline gradually over the next few years. Given the budget's reliance on revenue from natural resources, they encouraged the authorities to strengthen the non-hydrocarbon balance to generate additional savings over the medium- and long term. At the same time, it will be important to strike a balance between ensuring intergenerational equity and addressing nearterm physical and human capital needs.

Directors welcomed the fiscal reforms under consideration. They looked forward to steps to strengthen direct taxation, simplify the tax system, rebalance spending responsibilities and revenue assignments across the national and subnational levels of government, and establish a formal framework for the fiscal management of natural resources. Directors concurred that gradually phasing out fuel subsidies would create room for strengthening the fiscal position while further expanding development spending and social programs.

In the financial sector, Directors encouraged the authorities to focus on pending reforms while maintaining the existing strong financial supervision. Priorities are the creation of a deposit insurance scheme, the finalization of the preventative institutional framework for resolving insolvent financial institutions, and the expansion of the perimeter of regulation and supervision 
to cooperatives and other unregulated financial institutions. Directors welcomed the authorities' interest in an FSAP update. A few Directors encouraged further strengthening of the legislation on anti-money laundering and the operations of the Financial Intelligence Unit.

Directors stressed that-along with the promotion of public-private partnerships-improving the investment climate is key to boosting Bolivia's future growth prospects. They highlighted that the upcoming reform of the legal and institutional framework should lead to a clear and stable environment for private investment, including by introducing better procedures for enterprise restructuring to develop the domestic credit market.

Public Information Notices (PINs) form part of the IMF's efforts to promote transparency of the IMF's views and analysis of economic developments and policies. With the consent of the country (or countries) concerned, PINs are issued after Executive Board discussions of Article IV consultations with member countries, of its surveillance of developments at the regional level, of post-program monitoring, and of ex post assessments of member countries with longer-term program engagements. PINs are also issued after Executive Board discussions of general policy matters, unless otherwise decided by the Executive Board in a particular case. 
Bolivia: Selected Economic Indicators

\begin{tabular}{|c|c|c|c|c|c|}
\hline & 2006 & 2007 & 2008 & $\begin{array}{r}\text { Est. } \\
2009 \\
\end{array}$ & $\begin{array}{l}\text { Proj. } \\
2010\end{array}$ \\
\hline \multirow{2}{*}{\multicolumn{6}{|c|}{ (Annual percentage changes) }} \\
\hline & & & & & \\
\hline Real GDP & 4.8 & 4.6 & 6.1 & 3.3 & 4.0 \\
\hline GDP deflator & 13.7 & 7.4 & 10.4 & -1.5 & 4.1 \\
\hline CPI inflation (period average) & 4.3 & 8.7 & 14.0 & 3.5 & 3.3 \\
\hline $\mathrm{CPI}$ inflation (end-of-period) & 4.9 & 11.7 & 11.8 & 0.3 & 4.0 \\
\hline \multicolumn{6}{|c|}{ (In percent of GDP) } \\
\hline \multicolumn{6}{|l|}{ Combined public sector } \\
\hline $\begin{array}{l}\text { Revenues and grants } \\
\text { Of which: }\end{array}$ & 34.3 & 34.5 & 38.9 & 32.5 & 34.3 \\
\hline Hydrocarbons related revenue & 10.2 & 9.3 & 12.8 & 9.4 & 10.5 \\
\hline Expenditure & 29.8 & 32.8 & 36.5 & 32.6 & 34.7 \\
\hline Overall balance & 4.5 & 1.7 & 2.8 & 0.1 & -0.3 \\
\hline Total gross public debt & 55.2 & 40.9 & 37.5 & 39.4 & 37.4 \\
\hline \multicolumn{6}{|l|}{ External sector } \\
\hline Current account & 11.3 & 12.0 & 12.1 & 3.5 & 2.6 \\
\hline Merchandise exports & 33.6 & 33.5 & 38.8 & 27.4 & 29.0 \\
\hline Of which: Natural gas & 14.5 & 14.8 & 19.0 & 11.2 & 12.9 \\
\hline Merchandise imports & 24.4 & 26.0 & 30.0 & 24.9 & 27.2 \\
\hline \multicolumn{6}{|l|}{ Gross international reserves } \\
\hline In millions of U.S. dollars & 3,193 & 5,319 & 7,722 & 8,567 & 9,257 \\
\hline In percent of broad money & 62 & 75 & 85 & 82 & 78 \\
\hline \multicolumn{6}{|c|}{ (Changes in percent of broad money at the beginning of the period) } \\
\hline \multicolumn{6}{|l|}{ Money and credit } \\
\hline NFA of the banking system & 31.3 & 35.4 & 34.6 & 10.2 & 5.8 \\
\hline NDA of the banking system & -12.9 & -3.7 & -12.5 & 6.6 & 6.7 \\
\hline Of which: Credit to the private sector (in percent of GDP) & 34.7 & 33.1 & 30.3 & 33.0 & 36.1 \\
\hline Broad money & 18.5 & 31.7 & 22.2 & 16.8 & 12.5 \\
\hline \multicolumn{6}{|l|}{ Interest rates (percent, end-of-period) } \\
\hline Yield on treasury bills in local currency & 5.4 & 7.3 & 8.6 & $\ldots$ & $\ldots$ \\
\hline Yield on treasury bills in U.S. dollars & 4.9 & 4.6 & 4.0 & $\ldots$ & $\ldots$ \\
\hline
\end{tabular}

Sources: Bolivian authorities; and Fund staff estimates and projections. 


\section{Statement by Pablo Pereira, Executive Director for Bolivia and Victor Hugo De la Barra, Advisor to Executive Director January 15, 2010}

1. Bolivia has largely strengthened macroeconomic stability in recent years and has taken important strides in reforming its economy. Our robust macroeconomic policy framework managed to isolate the country from the international effects of the crisis providing confidence about economic stability and continuous growth. While the international crisis affected Bolivia through the trade channel in 2009, a clear positive growth has been achieved ( 3.3 percent) coupled with a substantial improvement in the standard of living of the population, thanks to the ample social programs that are aimed to reduce inequality in income distribution. Going forward, Bolivia's macroeconomic outlook is clearly favorable. To fully consolidate macro stability and achieve sustainable higher growth, reform efforts will be enhanced with greater reliance on an expanded role for the public sector as the engine of growth. The authorities have seized the opportunity of the favorable international commodity prices in 2006-2008 to accelerate the pace of fiscal consolidation, saving most of the additional revenue, maintaining control over current spending and using the available fiscal space to increase the much needed capital expenditure and expand the social safety net.

\section{Overview and Economic Outlook}

2. Underpinned by the 2006 National Development Plan, growth was 6.1 percent in 2008 and slowed down to 3.3 percent in 2009 due to the international shock. This rate was still among the highest in the region and real per capita GDP increased notably in the last three years. For 2010 the growth rate is expected to be greater than 4 percent, boosted by a significant level of public investment. The government's overall fiscal position recorded a small surplus in 2009 after reaching unprecedented surpluses in the last four years. Additional hydrocarbon revenues and a prudent fiscal stance during these years have contributed to a sustained stability, in spite of the international crisis. The gross debt-to-GDP decreased to 38 percent thanks to prudent debt policy after the debt relief. The current account still recorded a surplus of around 3.5 percent, while the ratio of international reserves reached a record of more than 50 percent of GDP in 2009.

3. The authorities remain cognizant that considerable challenges and reforms still lie ahead. Increasing investment for development, combating poverty and inequality and diversifying the economy though industrialization of domestic raw materials will reign in the government agenda. The political situation of Bolivia was undoubtedly strengthened in early December 2009 as President Evo Morales was reelected with more that 63 percent of the vote, which shows a high level of acceptance and popularity. The recent presidential elections reflect the fully democratic environment in which the current administration is engaged in and the government expects to implement additional structural reforms across all sectors within this framework. 


\section{Fiscal Policy}

4. In 2009, an accommodative fiscal stance effectively cushioned the economy from the global financial crisis. The Bolivian authorities believe that discretionary fiscal measures were needed to deal with these external shocks while preserving macroeconomic stability. The strategy proved to be truly effective. As a result of our robust policy framework, significant fiscal and external surpluses were achieved in the past three years, allowing the authorities room for maneuver to increase the level of public spending and maintain and expand social programs when needed the most. A key priority has been and will continue to protect the poor from the damaging effects of the international financial crisis. The public investment schedule could not reach the planned levels in 2009 due to difficulties in securing contracts for hydrocarbon exploration and drilling and also due to capacity constraints. Therefore, the government has planned public investment to reach approximately US\$ 2 billion in 2010 (around 10 percent of GDP), with a significant part financed by fiscal savings. Public investment will be allocated in infrastructure as well as in public enterprises to enhance goods production. The state oil company's plans to engage in an ambitious investment program financed in part by a billion-dollar loan from the Central Bank of Bolivia (CBB). It is expected that the hydrocarbons investment will spill over in the coming years, and an increase in private investment is also envisaged in this sector.

5. Expenses for health care and education will still be the main component of public expenditure in 2010. Social expenditure will be maintained as well as the cash-transfers such as the Bono Juancito Pinto to keep elementary school students on track, the universal retirement pension (Renta Dignidad) for people over 60s, and the Bono Juana Azurduy, another conditional cash transfer for pregnant women who attend regular pre-natal and pediatric checkups. As a result of these benefits, the poverty level has been reduced. Yet, the authorities are not comfortable with the current poverty levels and intend to reduce it further by expanding the social safety net and improving access to basic infrastructure. To this end, the authorities will continue to implement the Extreme Poverty Eradication Plan which started in 2009. In 2010, the minimum wage will be increased by 5 percent following the income redistribution policy. Additional resources to municipalities in poor regions will be available for targeted projects.

6. To boost fiscal revenue, the authorities are committed to continuously improve the efficiency of the tax-collecting agencies dealing with customs and domestic taxes. The implementation of the reform of taxation is under evaluation and the authorities expect to gradually apply it over the medium term. They also intend to diminish dependency on oil revenues as the economy diversifies as a result of additional public investment.

Nevertheless, the authorities are well aware of the level and effects of fuel subsidies and the needed cuts in this regard. This issue was raised by the authorities during the Article IV Consultation discussions, ahead of the staff's recommendation. In fact, the authorities have been working to find ways to implement targeted subsidies for hydrocarbons or differentiated subsidies for electricity, as a means to release resources for social expenditure. However, 
before proceeding to reform them, it is the view of the authorities that a well-targeted safety net must be put in place first to avoid negatively affecting the poor and most vulnerable segments of the population. In the case of hydrocarbons, Yacimientos Petroliferos Fiscales Bolivianos (YPFB) - the state oil company - will invest in the installation of domiciliary natural gas connections, which will reduce the use of the more expensive liquefied petroleum gas and consequently reduce the subsidy envelope. The authorities expect the fiscal stance to be balanced by the end of 2010 .

7. The need to balance the accumulation of financial savings for intergenerational equity and the more urgent demands for infrastructure, education, health and other social spending, are also of concern for the authorities. In this regard, the 2006 National Development Plan envisaged the creation of a fund financed out of public savings. Regarding a formal framework for managing the natural resource wealth, the authorities have been way ahead of the Fund staff's advice on this issue. A formal framework was already conceived and drafted in early 2006 and a draft law was prepared before the hydrocarbon nationalization. The framework already included a sovereign fund which would serve as a stabilizer for development purposes in case fiscal revenue falls short of the amount budgeted. Unfortunately, this policy could not be concreted since there were extreme dilatory tactics exercised by the opposition parties in the Senate. The authorities expect that the creation of this sovereign fund will be expeditiously considered in 2010 since the government has gained a majority in both chambers of the National Assembly. Nevertheless, in practice, the considerable amount of international reserves accumulated since 2006 has served as a stabilization fund by itself, which may be used as a financing cushion for public investment, a key driver for growth and employment in Bolivia.

\section{Monetary and Exchange Rate Policy}

8. The (CBB) has been easing monetary policy since end-2008 and cut its benchmark rate sharply in 2009, seeking to lower commercial lending rates and boosting banking credit to the private sector. In the same vein, the open market operations were reversed last year to allow a moderate expansionary stance in light of the need to boost domestic demand. Moreover, we are pleased to report that Bolivia accrued a historically low level of inflation in 2009 ( 0.26 percent) vis-à-vis an economy that expanded by 3.3 percent. This certainly complements the authorities' effort to further reduce poverty and inequality. The monetary expansionary policy will continue in 2010 , however, adjustments will be applied as warranted to control inflation developments. The expected developments in the economy allow a forecasted inflation of less than 4 percent for 2010.

9. The authorities are of the view that the CBB has to substantially contribute to economic development while preserving monetary stability as long as development financing is still a constraint for a country like Bolivia. For this reason, the authorities have authorized the CBB to finance YPFB for its prioritized investments in 2010. Given the comfortable level of international reserves - which are well above the level required according to the 
Fund-YPFB will temporarily borrow $\$ 1$ billion from the CBB to undertake projects aimed to augment the hydrocarbon production capacity for domestic and international markets. In the same vein, the 2010 Budget Law has included a special authorization for the CBB to grant an additional loan amounting to another $\$ 1$ billion for other strategic public enterprises which will also carry out other important investments. The authorities would like to stress that these are temporary measures that would allow to support strategically important investment needs (joint ventures and own enterprises) while other sources of financing are being designed. In particular, they are now considering tapping international financial markets to support the Bolivian public enterprises.

10. The CBB will continue to closely coordinate financial programming with the Ministry of Finance; in fact a Memo of Understanding between these institutions is signed every year in order to monitor the monetary and fiscal developments for stability purposes. Above all, President Evo Morales is strongly committed to macroeconomic stability as well as economic development to reduce poverty and strengthen the economy as whole.

11. The crawling peg regime has served Bolivia well. Since the start of the international crisis in the second half of 2008, the CBB - in light of the tremendous volatility of exchange rates around the world - decided to be cautious about allowing sudden movements in the value of the national currency vis-à-vis the U.S. dollar and neighboring countries' currencies in order to avoid inflationary pressures, keep the gains from the de-dollarization process of banking deposits, and signal stability in general. As a result, the nominal exchange rate has remained relatively unchanged since October 2008. In 2009 the exchange rate policy was supported by a very strong and still increasing level of international reserves, and a very low inflation. Pressures for nominal depreciation were notably contained, benefiting stability and creating more confidence with regards to the value of the national currency. By the fourth quarter of 2009, the boliviano started to depreciate in real terms while the current account kept its positive stance and international reserves reached record levels. At this time, the real exchange rate is in line with its fundamentals, meaning that the authorities were right about the exchange rate policy last year, avoiding volatility, containing the transmission of volatility of international markets to the domestic market, while being attentive to the country's international competitiveness. The CBB will continue to use the crawling peg regime and it stands ready for a more flexible exchange rate as warranted. The CBB authorities are committed to maintain the exchange rate around its equilibrium level in real terms.

12. Bolivia's current-account surplus for 2010 will be smaller but still positive (2.6 percent of GDP). On the one hand, demand and prices for natural-gas exports are expected to remain subdued - relative to 2008 levels - and imports may increase as a consequence of the public investment program. On the other hand, metal prices and other commodity prices are already showing a positive recovery. All in all, the prospects for international trade are encouraging as the global economy is rebounding. In the same vein, remittances to Bolivia 
are projected to recover in 2010. As a result, international reserves are expected to increase while public debt sustainability has improved.

13. As a result of positive signs about the strength of the external sector in 2009, international ratings for Bolivia have increased. Fitch—in September 2009-upgraded its rating on Bolivia. In fact, Bolivia's Foreign and Local Currency Issuer Default Ratings went up from "B-" to "B". Following the same pattern, Moody's moved Bolivia's Long-Term Foreign Currency Debt Rating up to "B2" from "B3".

\section{Financial Developments}

14. Bolivia's banking sector is healthy, liquid, profitable and well capitalized. Interestingly, in 2009 the sector recorded clear signs of improvement: nonperforming loans went down; provisions increased, and profitability also improved. Banking supervision was enhanced through countercyclical measures, such as the additional prevision on foreigncurrency denominated loans. Banks are very liquid and deposit interest rates are at a very low level. Credit has not grown as much as the deposits but the authorities expect that it will rebound in 2010 in light of better prospects for the economy as a result of the fiscal impulse in 2009 and the significant level of public investment in 2010. Credit risk regulations are serving the system well so far, and the supervision authority is working on strengthening its supervisory capabilities.

15. Additionally, the banking sector is enjoying an enhanced competence with the presence of one state-owned bank, which is operating following the rules of the market and has notably improved the quality of its services. Micro credit is expected to perform an increasing role in the credit market as more operators are seeking full license from the Authority for the Supervision of the Financial System (ASFI), which is now also in charge of supervising securities and insurance sector. Even though the banking system is healthy, the authorities are considering reviewing the current financial safety net at the time of the mandatory modifications of the financial system laws according to the New Constitution.

16. To further encourage commercial credit, the authorities are preparing additional legislation to rule on guarantees and collateral in order to foster the borrower profile and remove credit constraints. Along the same lines, they are working on insurance schemes for micro finances and raising additional funds for the stated-owned bank. The authorities have expressed interest in an FSAP to Bolivia's financial system, which may be useful for more efficient policy making, taking into account that the last FSAP was conducted in 2003.

17. Financial dollarization has significantly decreased since 2006. By the end of 2009, the domestic-currency deposits amounted to 44.2 percent compared to 42.4 percent in 2008 . This evolution is a consequence of the recent developments in macroeconomic policy as a whole, especially the trend of the exchange rate, the widening of the spread between the buying and selling exchange rate, the financial transaction tax - which is now levied only on foreign currency denominated operations - and the settling of inflation-indexed financial 
instruments, the use of which has slowed down significantly. The authorities intend to preserve the level of bolivianization on the banking system; therefore, they intend to cautiously manage the exchange rate and monetary policies.

\section{Development Policy and Structural Reforms}

18. In accordance with the New Constitution in place since January 2009, the new administration of President Evo Morales (as of January 2010) will start the preparation and implementation of several structural reforms aimed to support greater economic growth and social inclusion. Among these reforms is the approval of the Law of Autonomies, which will set up the new framework for enhanced decentralization and, consequently, new capabilities and responsibilities will be assigned to the newly created levels of autonomy.

Intergovernmental relations will also be ruled accordingly. In the same vein, laws for modifying the existing laws for the financial system, foreign investment, hydrocarbons, and others, will also be drafted and sent to the National Assembly.

19. The government has elaborated a new five-year plan which is coherent with the National Development Plan 2006-2010. This new plan is based on four strategies: 1) economic, aimed to increase productivity; 2) social-community oriented to improve the social safety net; 3 ) the international relationship aimed to insert Bolivia in the international community with enhanced negotiation capacity, and 4) political, and cultural ambits; and social empowerment oriented to strengthen democracy through promoting social inclusion. In this vein, in 2009, Bolivia managed to become an illiterate-free country, after executing a project that deployed personnel throughout the country to teach illiterate youth and adults.

20. Development of the hydrocarbons sector is still a key factor in Bolivia's future. Being aware of this, the authorities are doing their utmost to put in place a framework for the exploitation of their vast hydrocarbons reserves, allowing room for private investment. For that matter, the state oil company has planned an important amount of investments in the next five years amounting to more than $\$ 11$ billion in exploration and production seeking to reach 100 million of m3/day. The main partners will be Brazil and Argentina; with a new contract being sought with the latter. The projects included in YPFB's investment program will be implemented on their own or in association with foreign or domestic private enterprises. Mining is another key sector for the Bolivian economy. In addition to traditional minerals whose production may expand from 2010 onwards, the government is looking for partners to invest in the production and industrialization of lithium. Bolivia is considered to hold half of the world's lithium reserves from the Salar de Uyuni located in Potosi, in the high plateau region. As for electricity, the authorities plan to execute large projects to reach a substantial increase in generation capacity. As a result of the impulse of public investment, the Bolivian authorities expect to induce a greater growth rate vis-à-vis 2009, throughout the whole economy. 
21. The authorities are aware that private investment is important to growth and job creation, so they emphasize that public investment in different economic sectors will pave the way and add to further private investment. In some sectors such as hydrocarbons, investment schedules were not accomplished, not because there is an adverse business climate, but due to internal issues in YPFB and unfinished technical discussions with partners related to contracts and agreements. In addition, in 2009 the effects of the financial crisis were still active affecting investment across the world. Furthermore, last year was an electoral year in Bolivia, since there were important national calls for a vote such as the National Referendum to approve the New Constitution in January and the general elections for President, and congressmen in December 2009, along with regional referendums to decide the autonomy in four of the nine departments. It is important to note that in the last four years political tension in Bolivia was recurrent caused by the opposition leaders while the Constitutional Assembly was drafting the New Constitution. The government of President Evo Morales even had to recall ratification of its mandate in August 2008 to reiterate its legitimacy to pursue its reforms. Now all these problems have been resolved.

22. In the government program for 2010-2015 and in the National Development Plan there is a clear strategy for dealing with private entrepreneurs, based on the need to keep the sovereign rights and pursue a sustainable development. The government is aware that the business climate should be continuously improved through streamlined procedures for all potential investors and, especially, to attain the enlargement of small and medium-sized companies. These enterprises are labor intensive and their expansion would help reduce unemployment, which is the major cause of poverty.

23. To conclude, the overall good performance of Bolivia's economy in recent years is deeply rooted in its macroeconomic and development policies. Social inclusion has reigned in the policy agenda and will remain a key pillar of the government's economic strategy. The administration of President Morales is fully committed on the same path of fiscal discipline and pro-poor and pro-growth development policies. Brighter economic prospects lie ahead. 